\author{
UNIVERSIDADE DE SÃO PAULO \\ Faculdade de Filosofia, Letras E CiÊnCIAS Humanas \\ Departamento DE História \\ Programa de Pós-Graduação em História Social
}

Camila Cristina SOUZA LiMA

Arte, Técnica e Política: a arquitetura régia de Juan de Herrera e o projeto político de Felipe II da Espanha (1572 - 1597)

VERSÃO CORRIGIDA

SÃo PAULO

2012 


\title{
Arte, Técnica e Política: a arquitetura régia de Juan de Herrera e o projeto político de Felipe II da Espanha (1572 - 1597)
}

Dissertação de mestrado apresentada à banca examinadora, como exigência do Programa de Pós-Graduação em História Social da Faculdade de Filosofia, Letras e ciências Humanas da Universidade de São Paulo para a obtenção do título de Mestre em História. O exemplar original deste trabalho se encontra no Centro de Apoio à Pesquisa Histórica (CAPH).

De Acordo:

Profa. Dra. Ana Paula Torres Megiani (orientadora)

\author{
VERSÃo CORRIGIDA \\ SÃo PAULO




\section{AGRADECIMENTOS}

Gostaria de agradecer, primeiramente, à Fundação de Amparo à Pesquisa do Estado de São Paulo (FAPESP), pela bolsa de mestrado concedida pelo período de agosto de 2009 a agosto de 2011.

Também agradeço à minha orientadora, Profa. Dra. Ana Paula Torres Megiani e aos meus professores de graduação, Profa. Dra. Iris Kantor e Prof. Dr. Adone Agnolin, que fizeram surgir em mim o desejo de estudar História Ibérica Moderna.

Lembro ainda dos professores Paulo Garcez, Luciano Migliaccio, Renato Cymbalista e Mario Henrique d'Agostino, que conheci durante a pósgraduação e foram sempre muito atenciosos comigo.

Agradeço imensamente aos meus pais, Paulo e Marta, que entenderam minhas ausências, confortaram-me em todos os momentos difíceis e deram-me força, amor e alegria (e sentido) ao longo de toda a minha vida, e à minha irmã, Talita. Também agradeço às minhas avós, Lúcia e Maria de Lourdes, que mesmo sem entender ao certo porque eu saí tão cedo de casa, sempre rezaram por mim; e aos meus avôs, Joaquim e Irineu, cujas histórias foram as primeiras a me fazer olhar para o passado com curiosidade.

Agradeço também, a Éverton Amorim, que é fonte de muita força, inspiração e conforto desde que surgiu em meu caminho.

Agradeço a Luis Fernando Pereira, que já não está entre nós, por suas palavras, que me ajudam sempre que preciso de confiança.

Lembro também dos funcionários da Biblioteca Florestan Fernandes, (Faculdade de Filosofia, Letras e Ciências Humanas), e das bibliotecas do Instituto Cervantes, da Casa de Portugal e da Cátedra Jaime Cortesão. 
Aos meus amigos de graduação e aos amigos que dividiram comigo o alojamento e a moradia estudantil na USP, pelas boas lembranças e pelo apoio. Nesses anos fora de casa eles se comportaram como uma segunda família, a que sempre pude recorrer. Agradeço a Bruno Galeano, Márcio Botelho, Carla Milhosi, Adriana Silva, William Setubal, Brunela Succi, Juliana Massoni e Cristina Cardoso.

Agradeço também aos que compareceram à minha defesa da dissertação de mestrado, entre eles à querida Rosa Maria Tavares (sempre trazendo muito axé), Lílian e Marcos Flores Melim.

Por fim, agradeço a Bruno Macacari e aos seus pais, Gislene e Celso. Pelo incentivo deles e de minha mãe, um dia deixei a tranquila Jaú para viver na caótica e apaixonante São Paulo. 
A Paulo, Marta e Talita Souza Lima.

A Luis Fernando Pereira. 


\section{RESUMO}

Durante a Idade Moderna, na Espanha governada pela dinastia dos Habsburgos, religião e política se fundiam em muitos aspectos para criar a expressão característica da forma de governo desses monarcas, sobretudo durante o reinado de Felipe II (1556-1598). Junto a esse rei, importantes colaboradores criaram a imagem de seu governo. Nesta dissertação, chamamos a atenção para a atuação de Juan de Herrera, arquiteto de Felipe II, finalizador da obra emblemática do Monastério de San Lorenzo el Real del Escorial. Ao estudar a trajetória desse nobre, percebemos como a arquitetura ganha importância dentro da burocracia real, assim como as matemáticas. Herrera contribuiu para um projeto mais amplo do que a expressão estética e arquitetônica de um período, um projeto que expressava as inquietações políticas e religiosas da monarquia.

Palavras-chave: Espanha, Felipe II, Juan de Herrera, San Lorenzo del Escorial, religião, política. 


\section{ABSTRACT}

During the Modern Age, in Spain governed by the dynasty of the Habsburgs, religion and politics were fused in many aspects to create the characteristic expression of the form of government of these monarchs, especially during the reign of Philip II (1556-1598). Close to this king, important collaborators created the image of his government. In this thesis, we call attention to the work of Juan de Herrera, architect of Philip II, who completed the emblematic work of the Monastery of San Lorenzo El Real Del Escorial. Studying the trajectory of this noble, we realize how the architecture won importance within the royal bureaucracy, as well as mathematics. Herrera contributed to a more extensive project than the aesthetic expression and architectural design of a period, a project that expressed the political and religious inquietudes of the monarchy.

Keywords: Spain, Philip II, Juan de Herrera, San Lorenzo del Escorial, religion, politics. 


\section{LISTA DE IMAGENS}

Figura 01 - Figura 01 - llustração de Juan de Herrera para o "Libro de las Armellas". 20

Figura 02 - Vista desde o Monte Abantos do Monastério de San Lorenzo el Real de El Escorial. 23

Figura 03 - Medalha feita por Jacopo Trezzo, em comemoração à Basílica do Escorial e nascimento de Felipe III. 27

Figura 04 - Mapa da Península Ibérica com a localização das principais obras de Juan de Herrera.

Figura 05 - Fotografia da a fachada sul do Alcázar de Toledo. 33

Figura 06 - Fachada de São Vicente de Fora - Lisboa. .35

Figura 07 - Fachada da Catedral de Valladolid. .37

Figura 08 - Catedral de Valladolid em perspectiva. 38

Figura 09 - Detalhe do afresco de Luca Cambiaso para o Escorial. .53

Figura 10 - Gravura de Agostino Caraci - Escudo de Armas de Felipe II. .63

Figura 11 - Plano de Madrid. 78

Figura 12 - Estampa de Pedro Peret realizada a partir do desenho de Juan de Herrera para o Escorial. .83

Figura 13 - Ilustração da obra de Luis Cabrera de Córdoba, Felipe Segundo Rei de Espana, por Pedro Perret - 1619 . .85 
RESUMO

ABSTRACT

LISTA DE IMAGENS

CAPÍTULO I - A PERSONAGEM JUAN DE HERRERA

1.1. Trajetória do fidalgo que se fez arquiteto

1.2. Juan de Herrera e sua fortuna crítica

CAPÍTULO II - ARQUITETURA E MATEMÁTICAS PARA ORDENAR O REINO

CAPÍTULO III - A ORDEM DE SÃO JERÔNIMO E A IMAGEM DE UMA MONARQUIA CATÓLICA

3.1. A Ordem dos Jerônimos 109

3.2. O aspecto sagrado do Escorial e a Ordem de São Jerônimo 117

3.3. Portugal e Espanha: União Política e na Fé

CONCLUSÃo

REFERÊNCIAS

Fontes manuscritas

Fontes impressas 140

Bibliografia 


\section{INTRODUÇÃO}

“(...) imagens são feitas para comunicar. Num outro sentido elas nada nos revelam. Imagens são irremediavelmente mudas."

Peter Burke

Estudar a História da Espanha durante o reinado de Felipe II (1556-1598) da dinastia Habsburgo, implica, como qualquer outro recorte analítico, em algumas escolhas teórico-metodológicas. Dificilmente um trabalho surge sem que haja inspiração em estudos anteriores, seja pela admiração ou pelo desejo de afastamento e contestação das posturas tomadas pelos estudiosos frente às fontes. Dessa maneira, nessas primeiras páginas procuramos explicitar como construímos este trabalho a partir das inquietações que nos foram provocadas a partir da leitura da bibliografia apresentada.

Nossa pesquisa, em primeiro lugar, se refere a um rei, Felipe II (1527-1598) da Espanha, e seu arquiteto, Juan de Herrera (1530-1597). A proximidade entre monarca e arquiteto, desde a juventude de ambos na corte de Valladolid, e as diferentes atividades em que Herrera aparece associado à monarquia, têm muito a nos revelar sobre a relação entre arquitetura e poder na Espanha da segunda metade do século XVI.

Herrera construiu sua carreira como arquiteto para inserir-se na burocracia do governo espanhol, após ter servido como militar no reinado de Carlos $\mathrm{V}(1500-1556)$. Não se tornou primeiro tracista de edifícios para buscar depois se aproximar dos governantes. Devido à sua origem nobre, desejava ocupar seu lugar entre os cortesões, destacar-se entre seus pares. Diferentemente de nossa concepção atual do arquiteto enquanto artista, desejoso de deixar sua marca, ou buscar reconhecimento financeiro, as atividades de Herrera intencionavam a aproximação em relação ao monarca para servir-lhe e assim, alcançar distinção. Dessa maneira, sua formação como arquiteto se deu no ambiente da corte 
espanhola ${ }^{1}$, em meio às discussões que se processavam na arquitetura para se erguer edifícios para um mecenas ${ }^{2}$, Felipe II, atento ao que se realizava na Itália e em diversas cortes europeias, desejoso de tornar visível a imagem do seu poder nas igrejas, monastérios, palácios, obras de melhoria das cidades, etc.

Felipe II contava com uma vasta herança familiar, além das obras que foram realizadas durante seu reinado. Apenas citando os palácios tomados pelo rei como residência (ainda que nem todos estivessem terminados em seus anos de governo), há quatro edifícios de destaque, que serviram como morada ao monarca: os palácios de campo de Aranjuez (a cerca de vinte quilômetros de Madrid) e Valsaín (situado ao norte da Serra de Guadarama), o Palácio Monastério de San Lourenço el Real de El Escorial (localizado a cerca de quarenta e cinco quilômetros da capital) e o Palácio de El Pardo (que se encontra hoje no bairro madrilenho de El Pardo). ${ }^{3}$ Tais palácios formavam uma rede nas proximidades de Madrid, que se tornara a capital em 1561, quando a corte se transferiu para esta cidade ${ }^{4}$.

Tanto nos palácios herdados como em todas as edificações iniciadas ou reestruturadas durante o reinado de Felipe II, o monarca buscou imprimir unidade e representar seu poder através da arquitetura ${ }^{5}$. Para tanto, tornoua parte da burocracia estatal, sendo assim um instrumento a serviço da construção

\footnotetext{
${ }^{1}$ TAVARES, D. Juan de Herrera: disciplina na arquitetura. Porto: Dafne, 2005.
}

WILKINSON-ZERNER, C. Juan de Herrera: Arquitecto de Felipe II. Trad. Isabel Balsinde. Madrid: Ediciones Akal, 1996.

2 CHECA CREMADES, F. Felipe II mecenas de las artes. Madrid: Nerea, 1997.

3 GAYA NUÑO, J. A. Los monumentos cardinales de España. Vol. VI: Madrid Monumental. Madrid: Editoria Plus-Ultra, 1946.

\footnotetext{
${ }^{4}$ Felipe II transferiu sua corte (juntamento com o aparato burocrático estatal) para Madrid, em 1561. A partir de então, com exceção do período de 1601 a 1606, o centro administrativo da Monarquia Hispânica se fixou nesta cidade, que recebeu especial atenção dos reis para construir arquitetonicamente a imagem simbólica do poder que abrigava. Essa atitude substiruía a itinerância característica das cortes medievais.
}

BARREDO, M.J.R. Madrid, Urbis Regia. La Capital Cerimonial de la Monarquía Católica. Madrid: Marcial Pons, 2000.

5 WILKINSON-ZERNER, C. Op. cit. 
da imagem real. Juan de Herrera, como arquiteto do rei, tornou-se o principal responsável pela tarefa de construir o que identificamos hoje como o estilo real de Felipe II na arquitetura.

Após a morte de Juan Bautista de Toledo (Toledo, c. 1515 Madrid, 1567) ${ }^{6}$, arquiteto a serviço de Felipe II no inicio de seu reinado, Herrera se envolve em praticamente todas as iniciativas reais na arquitetura. Entre essas, a mais conhecida e lembrada é a finalização das obras do Palácio Monastério de San Lorenzo El Real del Escorial. Este edifício foi erguido em homenagem à primeira vitória espanhola alcançada durante o reinado de Felipe II, na Batalha de São Quintin, em 11 de agosto de 1556, dia de São Lourenço ${ }^{7}$. Essa construção, localizada junto ao monte Abantos, na Serra de Guadarrama, fica-nos como o principal símbolo do reinado de Felipe II, e será tratada ao longo desta dissertação. Também, conforme a posição de proximidade de Herrera em relação ao rei se fortalece, o arquiteto passa a atuar, em alguns casos, como intercessor entre o monarca e aqueles que desejavam permissão para publicações ou o seu mecenato ${ }^{8}$.

A importância de se compreender essa construção da imagem da monarquia e da inserção de Herrera dentro desse projeto parte de uma das características fundamentais da estruturação do poder monárquico na Europa Moderna. Quando consideramos as pinturas, esculturas, palácios, festas, ritos envolvendo a monarquia, precisamos pensar em expressões que não são meras representações, mas sim parte integrante de tudo o que significa o poder de um rei e de sua dinastia.

6 Juan Bautista de Toledo era arquiteto e atuou na Itália junto a Michelângelo, motivo que chamou a atenção de Felipe II para chama-lo de volta à Espanha para realizar as transformações que desejava na maneira de se edificar na Península Ibérica.

NIETO ALCAIDE, V. M. e CHECA CREMADES, F. El renacimiento: formación y crisis del modelo clásico. Madrid: Ediciones Istmo, 1993.

7 LACARTA, M. Diccionario Del Siglo de Oro. Madrid: Alderabán, 1996, p.356.

8 CERVERA VERA, L. Intervención de Juan de Herrera en Ediciones de Libros. Madrid: Instituto de Valencia de Don Juan, 1996.

HIGUERA, M. Á. , GÓMEZ MARTÍNEZ J., Herrera y su influencia: actas del simposio, Camargo, 1417 julio 1992. Santander: Ed. Universidad de Cantabria, 1993. 
Para compreendermos tal ideia, devemos salientar a importância de Marc Bloch, através de seu livro "Os reis taumaturgos", de 1924. Esta obra representou um marco na historiografia para se compreender o poder real ao colocar, no centro de suas preocupações, uma prática relacionada às monarquias francesa e inglesa entre os séculos XII e XVIII: o toque das escrófulas. Acreditava-se que os monarcas desses dois reinos eram capazes de curar, através do toque, uma doença que se manifestava com úlceras na pele, frequentemente com cheiro fétido as escrófulas - e seus súditos os procuravam com tal intuito. Apesar do longo período em que pode ser verificada, tal prática era, até o momendo das pesquisas de Bloch, relegada ao campo das superstições e curiosidades.

A postura de Bloch em tal obra amplia as fontes e questões que nos permitem estudar o poder real nas Idades Média e Moderna, pois considera que o milagre apenas existe quando se pode acreditar nele, ou seja, quando há um conjunto de ideias, valores e formulações teóricas que são compartilhados pela sociedade e que dão validade ao milagre. Dessa forma, através deste estudo podese compreender como o poder real se constrói, dentre outras maneiras, baseado na percepção da distinção entre aqueles que o detêm e seus súditos. Nesse caso, os reis também se afirmam em sua relação com o sobrenatural, o que explica seu lugar na sociedade enquanto representantes terrenos de Deus.

Desta maneira, percebemos que estudar as monarquias e as ideias relacionadas a esta forma de governo, vai além da leitura de tratados sobre o que se considera um bom governo, ou dos documentos eclesiásticos que tratam dos que reinam na Terra.

Para compreender o significado desse corpo distinto que se atribuía aos monarcas, devido ao poder que compreendiam em si, precisamos também considerar a tese de Ernst Kantorowicz, em sua obra sobre teologia política "Os dois corpos do rei" ${ }^{\text {,10 }}$. O autor dialoga com os estudos de história do direito

$9 \mathrm{BLOCH}, \mathrm{M}$. Os reis taumaturgos. O caráter sobrenatural do poder régio. França e Inglaterra. Trad. Júlia Mainardi. São Paulo: Companhia das Letras, 2005.

${ }^{10}$ KANTOROWICZ, E. H. Os dois corpos do rei. Um estudo sobre teologia política medieval. Trad. Cid Knipel Moreira. São Paulo: Cia das Letras, 1998. 
medieval, partindo inicialmente das formulações jurídicas da Inglaterra elisabetana sobre a natureza do poder dos reis, e como estes deveriam ser considerados com dois corpos: um corpo natural, mortal, sujeito a doenças, ao tempo e a problemas que ocorrem nos corpos de quaisquer outras pessoas comuns; e um corpo político, que não pode ser visto ou tocado, que não é mortal ou sujeito a defeitos ou erros.

É possível notar como os contemporâneos percebiam essa especificidade dos reis e filhos de reis, que se distinguiam dos demais devido ao poder político que carregam em si, no relato que nos faz Fernando Bouza sobre o encontro entre Francisco Gutiérrez de los Ríos e Córdoba, terceiro conde de Férnan Núnez, governante civil e militar de Cádiz em 1688, e um príncipe africano que fora vendido como escravo na Espanha:

"El conde refiere que, estando en el barco negreiro, se sintió atraído por el modo certeiro, aunque bárbaro, con el que el africano manejaba las armas, así como por el respeto que le dispensaban sus compañeros, reconociendo en él una certa prestancia que nacía del ' don de superioridade con que podemos crer que Dios caracteriza a los Principes, aunque sean bárbaros'."11

Mesmo no caso de um príncipe não cristão e "bárbaro", como qualifica o conde, sua realeza é visível aos demais, mesmo estando entre homens comuns e sendo vendido na condição de escravo. Tais palavras ajudam-nos a compreender essa visão tão distinta do poder em relação ao que vivemos atualmente, e nos aproximam do período estudado.

Considerando-se a teoria dos dois corpos do rei podemos compreender, também, como os reis eram percebidos nesse período e como tudo que os cercava tinha em si o peso da representação desse corpo político. O mesmo se percebe quando tratamos da arquitetura, que em si carrega o desejo do monarca de exteriorizar o seu poder.

No que diz respeito à forma como Felipe II buscou manifestar seu poder através da arquitetura, a linguagem utilizada tomou como referência a Itália

${ }^{11}$ BOUZA, F. La correspondencia del hombre práctico. Los usos epistolares de la nobleza española del Siglo de Oro a través de seis años de cartas del tercer conde de Fernán Núnñez (1679-1684). Anejos. In: Cuadernos de Historia Moderna. Madrid: Universidad Complutense de Madrid, 2005, pp.129-154, p. 130. 
renascentista ${ }^{12}$, que trazia, nos elementos da antiguidade clássica, reflexões sobre a relação entre as formas da arquitetura e aqueles que mandaram construí-la, uma ligação estreita entre o caráter do edifício e aqueles a quem foi encomendado ${ }^{13}$.

Segundo Fernando Checa $^{14}$, adotar a estética renascentista em um projeto coeso e sistemático de transformação da imagem dos edifícios reais significava, nesse momento, em primeiro lugar, utilizar-se de uma linguagem compartilhada e legitimada pelo uso tomado pelo papado e sua difusão em outras monarquias. Ou seja, a monarquia espanhola inseria-se no que havia de mais novo na arte de edificar e colocava-se, assim, em diálogo com o contexto arquitetônico europeu do século XVI. No reinado de Carlos V, já havia se incentivado algumas atividades nesse sentido, como seu palácio real com estética renascentista junto ao palácio de origem árabe de Alhambra. Mas, para além das intervenções pontuais de seu pai, Felipe II aumenta a importância dos arquitetos que poderiam criar uma imagem própria de seu reinado através da linguagem clássica.

Além disso, tal postura do rei visava demonstrar sua posição de destaque em relação à nobreza, que havia introduzido a estética italianizante no território espanhol em maior volume que os próprios monarcas ${ }^{15}$. A arquitetura servia para valorizar o lugar do governante na sociedade, em um momento em que esse poder estava se fortalecendo e buscando, em certos aspectos, centralizar-se.

Nesse sentido, a Monarquia Hispânica manteve seus territórios unidos garantindo a sobrevivência de certas leis, usos e costumes dos reinos incorporados, através, muitas vezes, da negociação com a nobreza local, como demonstra John Elliot em seus estudos ${ }^{16}$. Ao mesmo tempo, segundo Fernand

${ }^{12}$ CHUECA GOTIA, F. História de la Arquitectura Española. Ávila: Fundación Cultural Santa Teresa, Colégio Oficial de Arquitectura de Madrid, Universidade da Coriña, 2001.

${ }^{13}$ GARIN, E. Ciência e vida civil no Renascimento italiano. Trad. Cecília Prada. São Paulo: Editora Unesp, 1996.

${ }^{14}$ NIETO ALCAIDE, V. M.; MORALES, A. e CHECA, F. Arquitectura del renacimiento en España, 1488-1599. Madrid: Cátedra, 1993.

${ }^{15}$ Ibidem.

${ }^{16}$ ELLIOTT, J. H. España, Europa y el mundo de ultramar (1500-1800). Trad. Marta Balcells y Juan Carlos Bayo. Madrid: Taurus, 2009. 
Braude $^{17}$ e Geoffrey Parker ${ }^{18}$, durante o reinado de Felipe II, o monarca buscou ao máximo centralizar as decisões de seu governo em diversos aspectos, desde o que dizia respeito às guerras, relações diplomáticas e religiosas, até à arquitetura, que conferia o aspecto simbólico dessa união.

Podemos comparar esse uso das artes a serviço da imagem do poder real que deseja se afirmar, com as devidas ressalvas, ao caso do rei francês Luís XIV(1643-1715), estudado por Peter Burke. Apesar da distância temporal entre os dois monarcas, Luís XIV, que reinou na segunda metade do século XVII e inicio do XVIII, e Felipe II, que governou na segunda metade do século XVI, Burke chama nossa atenção ao demonstrar o quão estreita é a relação entre arte e poder nas monarquias da Europa moderna, relação que alcança seu ápice no projeto de construção da imagem do rei francês, o que Burke considera propriamente uma "fabricação" do rei ${ }^{19}$.

A obra de Burke é aqui lembrada por compreender como a imagem desse monarca foi criada através da atenção e controle de cada mínimo detalhe sobre tudo o que poderia representar o poder real. Assim, o balet, as pinturas, as jóias, o gestual e as vestimentas do rei, o tratamento que cada súdito poderia utilizar para se dirigir a ele, os jardins, os palácios, a música, etc., tudo estava a serviço da propaganda régia e expressava a relação estreita entre arte e poder. O termo propaganda é empregado pelo autor segundo nossa concepção atual, ou seja, um plano de ações utilizando diversas ferramentas que permitia à monarquia mostrar-se e afirmar-se, criando uma imagem construída propositalmente. Obviamente, devemos tirar desse sentido empregado pelo autor o caráter mercadológico do termo propaganda.

A busca por artistas, nesse caso, demonstra como se procurava afirmar a corte real como a mais importante entre as demais de seu território,

\footnotetext{
${ }^{17}$ BRAUDEL, F. El mediterraneo y el mundo mediterraneo en la época de Felipe II. Trad. Mario Monteforte Toledo e Venceslao Roces. México: Fondo de Cultura Economica, 1987.

${ }^{18}$ PARKER, G. Felipe II. Trad. Ricardo de la Huerta Ozores. Madrid: Alianza Editorial, 2004.

${ }^{19}$ BURKE, P. A fabricação do rei. A construção da imagem pública de Luís XIV. Trad. Maria Luiza X. de A. Borges. São Paulo: Zahar, 1994.
} 
rivalizando com as dos reinos vizinhos. É interessante ressaltar o fato de que, como Burke descreve, muitas vezes, as referências políticas de Luís XIV se encontravam em monarcas Habsburgos, entre eles o Imperador Leopoldo I (1658-1705) e Felipe IV da Espanha (1621-1665), neto de Felipe II.

Burke defende que muito do cerimonial adotado pelo rei francês foi elaborado a partir do que se realizava na Espanha. No entanto, em lugar da sobriedade dos Habsburgos e das aparições muito menos frequentes dos membros desta família, Luís IV adotou o fausto, a exuberância e a teatralização de todo o seu cotidiano como um espetáculo aos que viviam na corte. Até mesmo a escolha real de dar maior atenção a Versalles, um palácio que ao ser construído deslocaria a corte de Paris, estaria relacionada à iniciativa de Felipe IV de criar um palácio próximo à Madrid, o Buen Retiro.

A imagem da historiografia sobre Felipe II é, em muitos aspectos, praticamente o oposto de Luís XIV. Os quadros deixados por seus biógrafos, sobretudo as palavras de Geoffrey Parker ${ }^{20}$, mostram-nos um rei sempre ocupado com "os papeis" de seu reino, as cartas que chegam dos governantes que nomeou para os seus inúmeros e longínquos domínios. Um rei que tinha no Monastério de San Lorenzo del Escorial um lugar de fuga da vida na corte, onde podia se afastar dos olhares para se concentrar em seus afazeres políticos, além de encontrar nesse edifício um refúgio espiritual. Tal afastamento rendia-lhe, inclusive, pedidos e reclamações dos súditos, que desejavam ver mais frequentemente seu rei. No entanto, em sua sobriedade também se expressava o seu poder.

A imagem do rei não precisa ser vista diretamente para que se perceba sua presença, nem mesmo todos os súditos precisam ter acesso aos edifícios construídos pela monarquia. Uma arquitetura austera realizada pela coroa, apenas por ligar-se à sua imagem, tinha o poder de representá-lo. Segundo Bouza, a ideia de representação, no que diz respeito à monarquia, nos remete ao fato de que o rei se fazia presente através dos objetos, dos rituais, das cerimônias ${ }^{21}$. Dessa

\footnotetext{
${ }^{20}$ PARKER, G. Op. Cit.

${ }^{21}$ BOUZA ALVARES, F. Imagem y Propaganda. Capitulos de História Cultural del Reinado de Felipe II. Madrid: Akal, 1998.
} 
forma, Bouza compreende que, para este estudo, devemos levar em consideração os panfletos, estampas, o cerimonial das monarquias, o uso da arquitetura efêmera em casamentos, funerais, entradas reais, etc. Para compreender esse elemento do poder nas monarquias ibéricas, Bouza também se utiliza do termo propaganda, para qualificar a forma como o rei construía sua imagem aos seus súditos. Em suas palavras:

"a través de expedientes visuales, nada violentos como los que han mencionado, se hace reconocible, práctica y efectiva, la relación constitutiva entre distintos polos de ese poder - el rey y el reino o los señores y sus vasallos, por ejemplo. Por lo tanto, el poder se ve y, cuando no aparece, es imaginado. Esto es lo que ha hecho que en los últimos años se hayan multiplicado los estudios sobre fenómenos escasamente tratados anteriormente como la liturgia funeral o de consagración, las regalía, el cerimonial y la etiqueta de corte, las entradas reales, el ritual cívico, etc., etc."22

Ana Paula Torres Megiani também nos demonstra a importância do cerimonial como uma maneira do rei construir seu poder, como coloca Bouza, de forma "nada violenta". As entradas régias, como Megiani estudou no caso das visitas de Felipe II e Felipe III a Portugal ${ }^{23}$, ou mesmo as coleções de objetos, livros, animais, instrumentos, etc., realizadas pelos monarcas ${ }^{24}$ são elementos que demonstram a complexidade da representação régia, de como seu poder consegue fazer-se presente em seus reinos, e mesmo estar em diálogo com seus súditos.

Também devemos considerar a reflexão de José Maravall, em sua "Cultura do Barroco"25. Nessa obra, o autor sustenta que a sociedade moderna tem, no Renascimento e no Barroco, não apenas expressões estilísticas, mas também culturais e que, em ambos os períodos, o sentido da visão é privilegiado no

${ }^{22}$ BOUZA, F. e SANTIAGO, E. Grabar la Historia. Grabar en la Historia OLLERO, J. (ed.). Los Austrias. Grabados de la Biblioteca Nacional. Madrid: Biblioteca Nacional, 1993, p.18.

${ }^{23}$ MEGIANI, A.P.T. O Rei Ausente: festas e cultura política nas visitas dos Filipes a Potugal (1581 e 1619). São Paulo: Alameda, 2004.

24 MEGIANI, A.P.T. Memória e conhecimento do mundo: coleções de objetos, impressos e manuscritos nas livrarias de Portugal e Espanha. In: Anais do Museu Paulista. São Paulo, v.17. n.1, jan.- jun. 2009, p. 155-171.

${ }^{25}$ MARAVALL, J. A. A Cultura do Barroco: Análise de uma Estrutura Histórica. Trad. Silvana García. São Paulo: Edusp, 2009. 
que diz respeito ao conhecimento das coisas. Novamente percebemos a importância do elemento simbólico visual na Idade Moderna para se compreender o fenômeno analisado em torno de Felipe II, bem como outros monarcas de seu tempo. Nas palavras de Maravall:

"O valor da eficácia dos recursos visuais é incontestado na época. Vinha do fundo medieval a disputa sobre a superioridade do olho ou do ouvido para a comunicação do saber a outros. Enquanto no mundo medieval se optou pela segunda via, o homem moderno torna-se adepto da primeira, ou seja, da via do olho."26

Como também aponta Paolo Rossi ${ }^{27}$, muitas vezes pensamos erroneamente que a nossa sociedade é extremamente apegada à imagem, o que implicou, em alguns casos, na negligência dos historiadores em relação a essas fontes. Da mesma forma Burke ${ }^{28}$, ao estudar Luís XIV, nos chama à atenção o fato de que apenas era possível realizar uma propaganda minuciosamente fabricada porque a nobreza cortesã recebia, em sua educação, elementos que os tornavam sensíveis a inúmeros estímulos que lhes eram apresentados pelo monarca.

Para Maravall, o Barroco como fenômeno europeu teve, em sua expressão espanhola, enorme importância. A construção artística, estética, discursiva e estilística do Barroco revela o esforço de fortalecimento e centralização do poder monárquico, que se nota em muitos aspectos através desses recursos visuais. Segundo esse autor, "(...) os homens do Barroco sabem que a visão direta das coisas é extremamente importante. Dela depende que se estimulem movimentos de afeição, de adesão, de entrega."29 Cabe ao historiador perceber como esse poder se manifesta em documentos materiais de diversos suportes. Como aponta Guilherme Simões Gomes Jr:

"A questão do Estado tem para ele [Maravall] uma dimensão eminentemente simbólica: o modelo geométrico de uma companhia

\footnotetext{
${ }^{26}$ Ibidem, p.391.

${ }^{27}$ ROSSI, P. O passado, a memória, o esquecimento. Seis ensaios da história das ideias. Trad. Nilson Moulin. São Paulo: Editora Unesp, 2007.

${ }^{28}$ BURKE, P. Op. cit.

${ }^{29}$ MARAVALL, A. Op. Cit. p. 392.
} 
de soldados, a fundição de um metal para transformá-lo em canhão, os papeis ou objetos agenciados em uma repartição administrativa, são vistos não apenas em sua dimensão de coisas: [...] E o Estado, instrumento de poder absoluto do rei, há que ser visto como construção simbólica, artefato cultural que, na época barroca, articula mecanismos de persuasão e de violência até então impensável."30

Considerando as palavras de Maravall juntamente com as que apontamos anteriormente do historiador Fernando Bouza ${ }^{31}$, a monarquia se utiliza tanto de instrumentos "pacíficos", (como a arte, a arquitetura, os rituais, e inúmeras outras formas de representação de seu poder) quanto da violência como instrumentos de fortalecimento do poder, sobretudo na Europa da primeira metade do século XVII (que Maravall considera como Barroca), marcada pela conflituosidade e dramaticidade. As causas dessa tensão que caracteriza o Barroco não são apenas resultado da Reforma e Contra-Reforma, mas uma mudança significativa na sensibilidade e consciência de seus contemporâneos. Essas transformações se associam a causas múltiplas, culturais, políticas, sociais, econômicas, geográficas, técnicas e não apenas religiosas.

No que diz respeito especificamente ao reinado de Felipe II, Maravall considera que as ideias do Renascimento encontravam terreno fértil em seu governo, assim como no reinado de seu pai, Carlos V, devido às intensas atividades desses monarcas em promover práticas artísticas e letradas características desse período. Ainda segundo o autor, o processo de centralização do poder ocorrido durante esses dois governos é também um elemento renacentista.

Apesar do reinado de Felipe II se enquadrar no que Maravall considera como o renascimento espanhol, vale apontar as seguintes palavras do historiador, sobre os limites temporais do Barroco:

"Desde 1600, aproximadamente (apesar de certos fenômenos de precoce significação barroca terem sido enunciados anos antes, nos últimos momentos do maneirismo miquelangelesco e, entre nós, com a construção do Escorial), até 1670-80 (mudanças de conjuntura

\footnotetext{
${ }^{30}$ GOMES Jr., G. S. Prefácio. In: MARAVALL, J. A. A Cultura do Barroco: Análise de uma Estrutura Histórica. Trad. Silvana Garcia. São Paulo: Edusp, 2009, p.24.

${ }^{31}$ BOUZA, F. e SANTIAGO, E. Grabar la Historia. Grabar en la Historia. In: OLLERO, J. (ed.). Los
} Austrias. Grabados de la biblioteca Nacional. Madrid: Biblioteca Nacional, 1993. 
econômica e primeiras ressonâncias da ciência moderna na Espanha; Colber e o colbertismo econômico, político e cultural na França; arrancada decisiva da Revolução Industrial na Inglaterra) [tem-se o Barroco]." ${ }^{32}$

Essa dificuldade em se considerar e enquadrar completamente 0 reinado de Felipe II como experiência renascentista, sendo que Maravall encontra no Escorial uma expressão que antecipa o Barroco, nos coloca um dos principais dilemas em se estudar o século XVI. Costuma-se considerar que a Espanha vive, nesse período, suas experiências maneiristas ${ }^{33}$, o que significa que ainda se liga à linguagem clássica e aos modelos advindos do Renascimento, mas já apresentando a relação entre arte e Contra-Reforma, que viria a ser uma das características do Barroco.

O que se nota nesse período é a apropriação do modelo italiano com a intenção de expressar a ligação entre monarquia e religião. Não que se deseje antecipar as experiências posteriores, buscando a "semente" do Barroco nesse momento, mas é preciso salientar as aproximações e distanciamentos entre os momentos da História.

A arquitetura, nesse contexto, é um instrumento imprescindível ao rei, e Felipe II consegue controlá-la em muitos aspectos. Em primeiro lugar, porque sua expressão depende materialmente em grande medida daquele que a financia. Como aponta Norbert Elias ${ }^{34}$, a literatura e a filosofia puderam se autonomizar mais cedo em relação aos seus patronos (e depois "consumidores") do que a música e a arquitetura. O mercado editorial vai se constituindo a partir do advento da imprensa, criando um público consumidor relativamente anônimo, o que permite ao autor maior independência em relação ao gosto de seus leitores. A música e a arquitetura têm um custo mais elevado, e o mercado editorial de partituras, ou de traças, demora muito a se formar. Observa-se, portanto, que a arquitetura, assim como a música, é

\footnotetext{
${ }^{32}$ MARAVALL, J. A. Op. cit., p.42.

${ }^{33}$ NIETO ALCAIDE, V. M. e CHECA CREMADES, F. El renacimiento: formación y crisis del modelo clásico. Madrid: Ediciones Istmo, 1993.

${ }^{34}$ ELIAS, N. Mozart. Sociologia de um gênio. Trad. Sérgio Goes de Paula. Rio de Janeiro: Zahar, 1995.
} 
um dos elementos fundamentais para se compreender o poder nesse período, pois há enorme possibilidade de controle por parte daquele que a encomenda.

Devemos abordar, ainda, uma importante referência para esta pesquisa, no que diz respeito à História da Arquitetura: a obra de Manfredo Tafuri, "Ricerca del Rinacimento"35. Em tal obra, o autor mostra-nos a possibilidade de se conceber uma história da arquitetura em função das relações de poder que a envolvem. Cada capítulo apresenta-nos, com riqueza de detalhes, o contexto em que se construíram as obras estudadas, e como cada uma delas prestava-se a uma demonstração de poder por parte de seu realizador. Sua postura aponta para a construção de uma História da Arquitetura para além daquela que leva apenas em conta os elementos estéticos e inovações técnicas relacionadas aos edifícios. Os acontecimentos narrados e analisados por Tafuri mostram as intenções daqueles que executavam as obras, bem como daqueles que as financiavam, além de buscar compreender a capacidade que tais obras tinham de transmitir uma mensagem.

Como apontamos nessas páginas, buscamos compreender o papel de Juan de Herrera dentro da formulação da imagem de Felipe II. Para tanto, consideramos que o poder político pode ser compreendido, dentre outras maneiras, através da arquitetura. Assim, dividimos a dissertação em três partes, sendo que a primeira se ocupa da trajetória de Herrera enquanto arquiteto de Felipe II e das interpretações da historiografia sobre seu papel junto ao monarca. Buscamos com nesse capítulo explicitar as especificidades da carreira de Herrera e como ele está completamente inserido no projeto arquitetônico do monarca.

No segundo capítulo nos ocupamos das matemáticas e da arquitetura como dois instrumentos do governo, utilizados para organizar e representar o rei em seus territórios. Procuramos demostrar nesse capítulo como Herrera participa desse projeto, lembrando que sua formação esteve sempre relacionada ao contexto da corte espanhola e, consequentemente, às necessidades da arquitetura segundo os desejos do rei.

\footnotetext{
${ }^{35}$ TAFFURI, M. Ricerca del Rinacimento. Principi, città, architetti. Torino: Einaudi, 1993.
} 
No terceiro capítulo, por fim, colocamos a discussão sobre a ligação da Ordem de São Jerônimo e os edifícios régios. Buscamos demonstrar a importância da religião aliada à formulaçao da imagem da monarquia espanhola. Esses três capítulos colocam o papel do arquiteto Juan de Herrera em atividades relacionadas à construção da imagem da monarquia entre seus contemporâneos e a memória do reinado de Felipe II, valorizando os elementos que marcassem o pertencimento dos diferentes territórios à história da Península Ibérica. 
CAPÍTULO I - A PERSONAGEM JUAN DE HERRERA 


\subsection{Trajetória do fidalgo que se fez arquiteto}

Para compreender o papel da arquitetura como instrumento da administração do reinado de Felipe II devemos tomar, em primeiro lugar, a trajetória de ascensão de Juan de Herrera como arquiteto do rei. Existem muitas lacunas na documentação sobre determinados momentos da vida deste homem, sobretudo nos anos que antecedem a sua presença na corte. Porém, os dados que são conhecidos revelam a inserção de sua carreira na corte espanhola, onde esteve atento às ideias e necessidades específicas relacionadas à arquitetura que seria realizada para essa monarquia.

Juan de Herrera tinha origem nobre, de uma família destituída de herança. Seu avô, Rui Gutiérrez de Maliaño, foi senhor de Maliaño e mayorasgo de Herrera, com ricas terras nessa região. Seu pai, Pedro Gutiérrez de Maliaño, era fruto do segundo casamento de Rui Gutiérrez. Herrera teve apenas uma irmã que chegou à idade adulta, chamada María. Os bens de seu pai e sua mãe, Maria Gutiérrez de la Vega, eram escassos, sendo que Herrera comprou-os posteriormente, por duzentos ducados ${ }^{36}$.

\footnotetext{
${ }^{36}$ As referências que foram utilizadas pelos biógrafos para traçar a vida de Juan de Herrera se encontram no Memorial de 1584, que transcrito na obra de realizada por Eugenio Llaguno Amirola com o título, "Cópia de una memoria original que Juan de Herrera envió a Mateo Vázques...", publicado originalmente em 1829:
}

LLAGUNO, E. Notícias de los arquitectos y arquitectura de España desde su restauración. Madrid: Imprenta Real, reed., 1977, vol.2, 332-9.

A interpretação desse texto se encontra nas obras:

ARAUTE, R.; CERVERA VERA, L. Semblanza de Juan de Herrera. IV Centenario de la fundación del monastério de San Lorenzo de El Escorial, 1563-1963, Madrid: [s./n.] 1963, vols. 2, pp. 07-103.

CERVERA VERA, L. Esquema biográfico de Juan de Herrera, arquitecto humanista, intérprete de los cânones vitruvianos. in: Homenaje a Juan de Herrera. Santander: Fundação Juan de Herrera, 1988, p. 13-34. 
Devido a essa origem de Herrera, havia alguns caminhos possíveis para garantir um lugar junto à nobreza e ter uma vida de distinção. As trajetórias mais comuns buscadas pelos fidalgos estavam na Igreja e no exército. Um bom casamento e os serviços à coroa também poderiam garantir rendimentos e um lugar de prestígio.

Pela maneira como Herrera buscava sair dessa posição, na qual se encontravam muitos nobres ibéricos, Domingos Tavares define-o como "fidalgo de fracas posses e muitas ambições"37. Não podemos confirmar tal juízo de Tavares sobre o arquiteto, pois a tentativa de buscar recursos e privilégios por parte dos nobres não era uma postura estranha ou excepcional no período ${ }^{38}$. Com tal intuito, partiu muito cedo de sua terra natal, no município de Roiz (Valdáliga), na Cantábria, havendo indícios de sua chegada à corte de Valladolid aos dezessete anos, em 1547.

Logo em 1548, Herrera faria parte do grupo de jovens cortesãos que viajavam com Felipe à Bruxelas e à Itália e que, dessa forma, ganhavam conhecimento dos assuntos políticos do príncipe regente. Como nos coloca Catherine Wilkinson-Zerner ${ }^{39}$, dos dois caminhos mais prováveis para buscar

Essas obras são base para a apresentação da vida de Juan de Herrera pelos historiadores da arquitetura Domingos Tavares e Catherine Wilkinson-Zerner e que são nossas referências sobre a trajetória deste arquiteto.

TAVARES, D. Juan de Herrera. Disciplina na arquitetura. Porto: Editora Dafne, 2005.

WILKINSON-ZERNER, C. Juan de Herrera: Arquitecto de Felipe II. Trad. Isabel Balsinde. Madrid: Ediciones Akal, 1996.

${ }^{37}$ TAVARES, D. Op. cit., p.34-35.

38 Em certa medida, a visão de Tavares mostra-se muito apegada às nossas concepções contemporâneas de busca de reconhecimento financeiro pelas atividades que desenvolvemos.

TAVARES, D. Op. cit.

BENNASSAR PERILLIER, B. Los hidalgos en la España de los siglos XVI y XVII: uma categoria clave. In: idem; et. al. Vivir el Siglo de Oro. Poder, Cultura e História en la época moderna. Estudios en homenaje al profesor Ángel Rodríguez Sánchez. Salamanca: Universidad de Salamanca, 2003, pp. 49-60.

${ }^{39}$ WILKINSON-ZERNER, C. Op. cit., p. 08. 
privilégios junto à corte, a Igreja ou o Exército, o nobre cantábrio voltou-se à carreira militar.

Juan de Herrera alistou-se em 1553, sob o comando do capitão Medinilla, integrando as tropas imperiais dos Habsburgos no Piemonte. Depois, em 1554, alistou-se na guarda de Ferrante Gonzaga, dirigindo-se às campanhas de Flandres. Após este último serviço, passou a fazer parte da guarda pessoal de Carlos V em Bruxelas, a chamada "guarda alemã". Em 1556, quando Carlos V abdica de seus domínios, Herrera deixa de aparecer nas listas dos poucos servidores que continuaram ao lado do imperador em seu último retiro, no Monastério de Yuste ${ }^{40}$.

Nessas viagens, realizadas como cortesão a serviço do príncipe regente Felipe e como militar, Herrera também conheceu a arquitetura realizada em Flandres e Itália ${ }^{41}$.

Ainda como soldado, Herrera entrou em contato com importantes nomes da cultura espanhola daquele tempo. Em primeiro lugar, quando servia a Carlos V, com Juanelo Turriano (c.1500-1585), matemático natural de Cremona, construtor de relógios e inventor da máquina hidráulica para elevar a água do rio em Toledo, conhecida por "artífice de juanelo"42. Segundo Domingos Tavares, desse encontro resultaria uma importante mudança na vida de Herrera, que começaria a se interessar pela aquisição de conhecimentos no campo da ciência e da técnica e

\footnotetext{
${ }^{40}$ A lista mencionada por Catherine Wilkinson-Zerner encontra-se no arquivo francês do Ministério dos Assuntos Estrangeiros (Archives du Ministère del Affaires Etrangères - AMAE):
}

AMAE, Memóires el Documents, Fonds Divers, vol. 225, fol. 330r-343v.: "Relación de los criados que el Emperador Carlos V tenía al tempo que deshizo su casa por el mês de junio de 1556" (listas de los membros de la casa). Apud. Wilkinson-Zerner. Op. Cit., p.08.

${ }^{41}$ CHECA CREMADES, F. Felipe II mecena de las artes. Madrid: Nerea, c. 1992.

${ }^{42}$ ESTEBAN PIÑEIRO, M. La ciencia en el siglo XVI español. In: HOURCADE, J. L. G.; YUSTE, J. M. M. Andrés Laguna. Humanismo, Ciencia y Política en la Europa Renacentista. Congresso Internacional (Segovia, 22-26 de noviembre de 1999). Madrid: Junta de Castilla y León; Consejería de Educación y Cultura, 2001, pp.22-40. 
desenvolveria capacidades pessoais de sistematização e organização, sendo que os dois mantiveram colaboração permanente a partir de então ${ }^{43}$.

Num segundo momento, após a morte de Carlos V, quando passou a prestar serviços a Felipe II, Herrera conheceu Honorato Juan (1507 1566), professor da Universidade de Alcalá de Henares ${ }^{44}$, que Ihe encomendou desenhos para a cópia de um tratado de astronomia, uma reprodução de um códice medieval chamado "Libro de las Armellas", escrito durante o reinado de Afonso X (1221-1284), o Sábio. Juan de Valencia (? - 1591), que depois se tornaria ajudante de Juan Bautista de Toledo ao lado de Herrera, foi encarregado de copiar o manuscrito. Hoje, encontra-se na Biblioteca do Escorial um exemplar desta edição, realizada em $1562^{45}$.

A partir desse serviço, pela primeira vez o talento de Herrera no desenho foi percebido, o que posteriormente lhe possibilitaria atuar nas obras do Monastério de San Lorenzo el Real del Escorial. Até sua inserção nos serviços à coroa neste edifício, Herrera continuaria prestando serviços a Honorato Juan, mas quase não há referências sobre sua vida nesses anos. Não é possível precisar se o fidalgo havia estudado arquitetura até este momento, ou se iniciara seu aprendizado com seu mestre no Escorial.

\footnotetext{
${ }^{43}$ TAVARES, D. Op. cit., p.35

${ }^{44}$ Honorato Juan nasceu em Valência, em 1507, e atuou entre os mais destacados humanistas espanhóis do século XVI. Foi discípulo de Juan Luís Vives (1492-1540), contemporâneo e amigo de Erasmo de Roterdã. Honorato Juan teve papel destacado por ter sido incumbido por Carlos $\mathrm{V}$ da formação de seu herdeiro, que se tornaria Felipe II. Este último, já como monarca, também encarregou Honorato Juan da educação do príncipe Carlos. Sobre essa personagem fundamental do humanismo espanhol, Francisco José Sanchis Moreno escreveu a obra:
}

SANCHIS MORENO, F. J. Honorato Juan: vida y recuerdo de um maestro de príncipes. Valência: Biblioteca Valenciana, 2002.

${ }^{45}$ Essa referência encontra-se no livro de Fernando Checa, mas sem maiores especificações:

CHECA CREMADES, F. Op. cit., p.310. 


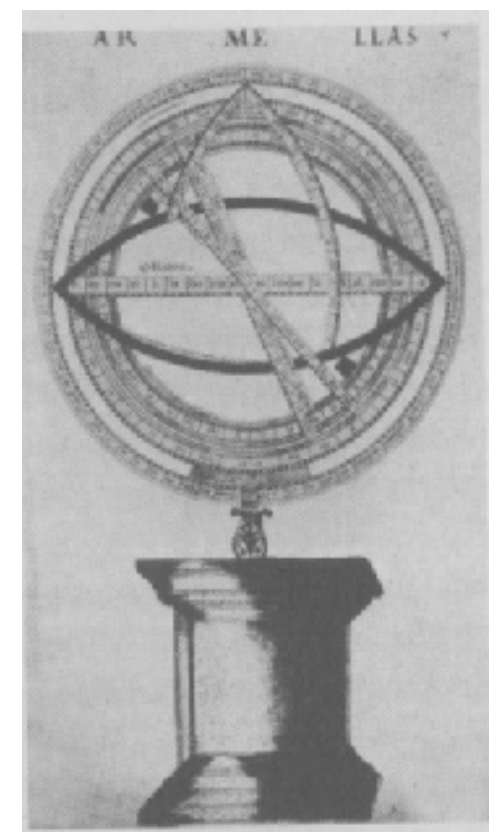

Figura 01 - Ilustração de Juan de Herrera para o "Libro de las Armellas".

Fonte: TAVARES, D. Op. cit., p. 36.

A construção do Monastério de San Lourenço el Real de El Escorial, obra na qual Herrera inicia seus serviços em arquitetura à coroa, ocorreu entre 1563-1585, ocupando um longo período dentro do reinado de Felipe II, e foi realizada após a Batalha de San Quintín, entre franceses e espanhóis. Nas palavras do Padre José de Siguenza $(1544-1606)^{46}$ :

${ }^{46}$ O Padre Siguenza nasceu na cidade de Siguenza, Guadalajara. Era filho de um clérigo, Asensio Martínez, e uma viúva, Francisca Espinosa. Sua carreira religiosa iniciou-se em 1556, no Monasterio Del Parral, em Segóvia, que existe até hoje e continua a abrigar a ordem de São Jerônimo. Tornou-se Bacharel em Artes pela Universidade de Salamanca e depois ingressou na Ordem dos Jerônimos. Em 1590 transferiu-se definitivamente ao monastério do Escorial, onde viveu durante os anos mais decisivos e dramáticos de sua vida junto à coroa. Foi processado pela Inquisição e absolvido. Escreveu a "História primitiva y exacta del monasterio del Escorial" , a qual consultamos para realizar esta pesquisa. Também escreveu "La Historia de la Ordem de San Jeronimo", que é a principal referência à história desses monges cuja existência está circunscrita aos limites territoriais da Península Ibérica. Foi elevado a prior duas vezes e faleceu em 1606. Foi historiador de Felipe II, hebraísta, bibliotecário da Biblioteca do Escorial.

DÍAZ DÍAZ, T. "El entierro de San Lorenzo", posiblemente el mejor cuadro de Juan Fernández de Navarrete "el Mudo" (Padre Sigüenza). In: JAVIER CAMPOS, F. e SEVILLA, F. de (coord..). EI Monasterio del Escorial y la pintura: Actas del Simposium, 1/5-IX-2001 / , 2001, págs. 561-580. 
"Fué ésta la primera de las victorias que tuvo Felipe II, y acertó por celestial acuerdo á ser en 10 días de Agostos, fiesta del glorioso mártir San Lorenzo, español, á quien su niñez tuvo este piadoso Príncipe singular devoción: entendió que un principio tan ilustre de suas cosas le venía por su favor e intercesiones en el cielo, y así, desde aquel punto, concebío en su pecho un alto propósito de hacerle algún señalado servicio." 47

Esta obra tornaria-se, como colocaremos adiante, o principal símbolo da monarquia de Felipe II. O Monastério do Escorial, como é conhecido, compreende um conjunto arquitetônico complexo e grandioso. É composto pelo monastério propriamente dito, os aposentos reais que formam o palácio e a basílica, além dos jardins. A localização foi pensada para garantir tranquilidade ao monarca e aos monges que alí habitariam, além de ter-se levado em consideração o relevo, que precisava apresentar uma grande área relativamente plana para se realizar uma obra grandiosa:

"En la ladera de esta sierra [Guadarrama], junto a una pequena población que se llama Escorial (...) se descubrió una llanura ó plaza, suficiente para uma gran planta, y el contorno de la tierra lleno de muchas comodidades para el propósito"48

Sobre a obra de José de Siguenza que trata da história da Ordem de São Jerônimo, há a seguinte edição:

SIGUENZA, J. Historia de la Ordem de San Jerônimo. Madrid: Casa Editorial Bailly-Ballière, 1902.

${ }^{47}$ Essa justificativa dada pelo padre historiador da ordem de São Jerônimo, José de Siguenza, que acompanhou a contrução do monastério de San Lorenzo el Real del Escorial, aparece também em muitos autores da bibliografia e em outros documentos analisados para esta pesquisa de mestrado. Não há muitas referências sobre essa batalha, nem ao menos, pelo o que tudo indica, foi uma batalha de grande impacto para o reinado de Felipe II, que há pouco se iniciara. Uma possível hipótese sobre a escolha dessa batalha se deve à data da vitória, como um sinal celeste de aprovação ao reinado de Felipe II, de proteção e afinidade entre as ações do monarca e a vontade divina.

SIGÜENZA, Frei J. História primitiva y exacta del monasterio del Escorial. Madrid: Imprenta y Fundacion de M. Tello, Impresor de Câmara de S. M. Isabel la Católica, 23, 1881. Edición Fac-simile. Valladolid: Editorial Maxtor, 2003, p.13.

${ }^{48}$ Ibidem, Discurso II, p. 26. 


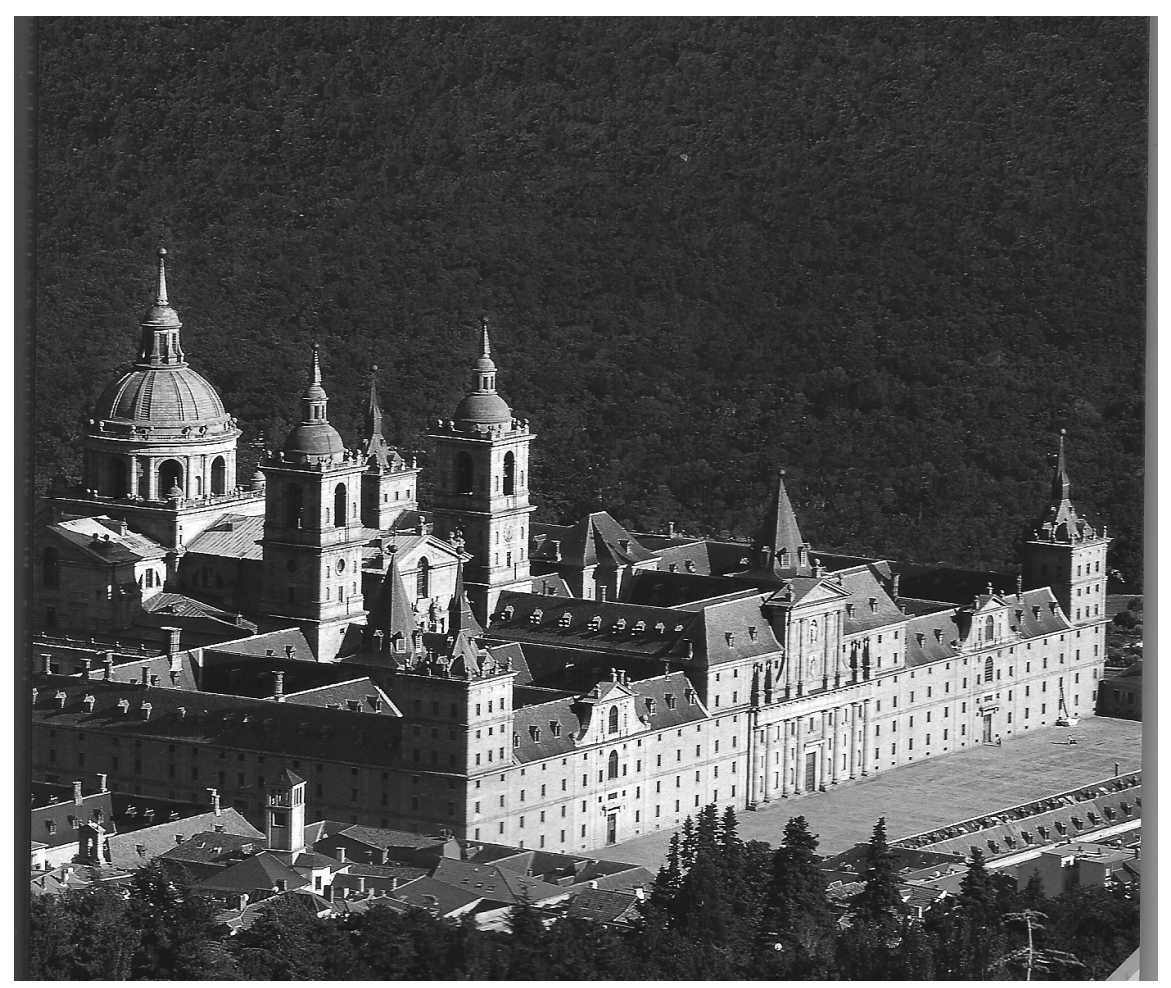

Figura 02 - Fotografia de Félix Lorrio Aldesa/José Barea - Vista desde o Monte Abantos do Monastério de San Lorenzo el Real de El Escorial, c.2010.

Fonte: GARCIA-FRIAS, C.; SANCHO, J.L. Real Monasterio de San Lorenzo de El Escorial. Madrid: Patrimônio Nacional, 2010, capa.

Para realizar essa obra em homenagem a São Lourenço, santo mártir espanhol, o monarca trouxe da Itália Juan Bautista de Toledo. As palavras do padre historiador José de Siguenza são elogiosas para qualificar o arquiteto escolhido: “(...) Juan Bautista de Toledo, varon de gran juicio y excelente maestro en arquitectura (...),49.

Alguns infortúnios durante a transferência do arquiteto para a Espanha custaram-lhe a perda da família, deixando-o sempre muito desgostoso enquanto trabalhava à serviço da coroa espanhola. Além disso, as opiniões distintas do arquiteto e do monarca sobre a concepção da obra fizeram com que a relação entre rei e artista fosse marcada por uma permanente disputa na tomada de decisões. Na história da fundação do Monastério do Escorial de Siguenza, aparece-

\footnotetext{
${ }^{49}$ Ibidem, Discurso II, p.31,
} 
nos o seguinte relato, que nos ilustra um dos episódios em que essa disputa é percebida:

"El principal cuidado que S. M. tenia en esta fabrica era la iglesia, por ser como el fin último, y digámoslo así, el todo de lo que se pretendia. La primera parte e más grave dificuldade fue convenir en la traza; la que había dado Juan Bautista de Toledo no le contentaba mucho el Rey, le pareció cosa comum, dejado que no respondia bien con sus pensamentos; se trajeran muchas de diferentes partes $(\ldots)^{, 50}$

Mesmo com as tensões existentes entre arquiteto e rei, já se delineava a preferência real por um artista nos moldes renascentista, que fosse um homem versado nas discussões teóricas, que se distanciava do estatuto de artesão, ou, como no caso específico da arquitetura espanhola, dos "maestros mayores", dos quais trataremos adiante. Na obra de Siguenza, são recorrentes as considerações sobre o valor dos conhecimentos dos antigos na arte de edificar e das discussões com artistas italianos, como os que enviaram as traças para que o rei avaliasse qual desenho melhor convinha ${ }^{51}$.

Vale lembrar que até fins da Idade Média, o arquiteto era visto como um trabalhador manual, como parte da camada baixa da sociedade e sem o caráter de diferenciação social. Na Península Itálica, a elevação do estatuto do arquiteto como artista se dá paralelamente ao desenvolvimento econômico das cidades, e no processo de distinção entre cidade e corte $^{52}$. Já na Monarquia Hispânica, essa mudança se inicia com os serviços realizados por Juan Bautista de Toledo para Felipe II e consolida-se com Juan de Herrera, ou seja, a partir das iniciativas régias ${ }^{53}$.

\footnotetext{
${ }^{50}$ Ibidem, Discurso VIII, p. 91.

${ }^{51}$ Siguenza coloca: “(...) los antigos, que sabian tanto y procedian en sus cosas con tanta consideracion(...)"

Ibdem, Discurso IV, p. 40.

52 WARNKE, M. O artista da corte: Os antecedentes dos artistas modernos. Trad. Maria Clara Cestato. São Paulo: Edusp, 2001.
}

53 WILKINSON-ZERNER, C. Op. cit., p.21. 
Além disso, Siguenza também qualifica mais detalhadamente a figura de Juan Bautista de Toledo nas seguintes palavras:

"Architecto mayor, que iba haciendo la idea y el diseño desta fabrica [o Escorial]; hombre de muchas partes, escultor y que entendia bien el dibujo; sabia lengua latina y griega, tenía muchas notícias de Filosofia, y Mathemáticas, hallábanse al fin en él en muchas de las partes que Vitrubio, príncipe de los arquitectos, quieri que tengan los que han de exercitar al arquitetctura y llamarse maestros en ella" ${ }^{\prime \prime}$

Dessa maneira, o autor valoriza, entre os atributos de Toledo, algo mais do que apenas realizar as traças e outras habilidades que hoje compreendemos como exclusivas da arte de edificar. Toledo é valorizado por conhecer latim e grego, o que the permite ter acesso a uma gama alargada de textos, já que estava se processando ainda a tradução de obras clássicas para as línguas vernáculas ${ }^{55}$, e valorizava-se a leitura dos textos clássicos em sua língua original. Também tinha conhecimentos de Filosofia e Matemáticas.

Além disso, Siguenza enfatiza os conhecimentos de Toledo sobre os preceitos de Vitrúvio (séc. I a.C), que fora arquiteto do imperador romano Otávio Augusto (63 a.C.-14 d.C) e que escreveu o tratado "De architetura", único tratado de arquitetura que nos ficou da antiguidade clássica. Os dez livros que compõem a obra de Vitrúvio foram fundamentais para que se construísse a concepção renascentista de arquitetura, pois são as únicas fontes que nos fornecem considerações teórias sobre os edifícios romanos que os homens modernos conheciam através das ruínas e, por esse motivo, foram tomados como cânone pelos artistas dos séculos XV e $X V I^{56}$.

Neste contexto, inserida no projeto para o Escorial, a carreira de Herrera junto a Juan Bautista de Toledo iniciou-se a partir de uma carta real em

\footnotetext{
${ }^{54}$ SIGUENZA,J. Op. cit., Discurso III, p. 37-38.

${ }^{55}$ Sobre o assunto, trataremos mais adiante, sobretudo apresentando a contribuição de Juan de Herrera para que se publicassem livros "científicos" em castelhano.
}

CERVERA VERA, L. Intervención de Juan de Herrera en Ediciones de Libros. Madrid: Instituto de Valencia de Don Juan, 1996.

${ }^{56}$ VITRUVIO. Tratado de Arquitetura. Trad. M. Justino Maciel. São Paulo: Martins Fontes, 2007. 
$1563^{57}$, onde Felipe II o nomeava, junto com Juan de Valencia (? - 1591), ajudante do arquiteto real: Herrera no Escorial e Valencia nas demais edificações reais do momento (em Madrid, Toledo e Aranjuez). Juan de Valencia era enteado de Luis de Vega, que fora maestro mayor do Alcázar de Madrid e the introduziu nos conhecimentos da arquitetura. Ambos, Herrera e Valencia, tinham atuado a serviço do tutor real, Honorato Juan, como mencionado. Esse momento marcou a exteriorização das dificuldades do rei em lidar com seu arquiteto. Toledo viu com desconfiança seu ajudante no Escorial, e o considerava um fiscal a serviço do rei, tratando-o, muitas vezes, com certo desprezo, como o "soldado da guarda alemã"58.

A partir desse momento, como auxiliar de Juan Bautista de Toledo, Herrera se fez arquiteto. Aprendeu arquitetura no decorrer da obra com esse mestre e foi conquistando espaço como servidor da coroa. Para além da demonstração de seu talento, esse nobre buscou na arquitetura uma forma de destaque e de obtenção de rendas, o que não era uma atitude esperada ou comum nesse momento, sendo apenas possível porque a arquitetura se tornava, então, um ramo da administração estatal. Ordenada segundo uma burocracia regular, assim como outros serviços à coroa, passou a ser a porta de entrada para se buscar garantias de patrimônio e reconhecimento junto ao rei.

Herrera se ocupou, durante o período em que foi ajudante do arquiteto do rei, em adquirir conhecimentos cada vez mais elaborados não apenas em arquitetura, mas também em matemática e engenharia. É muito citada pela historiografia a atenção dada por Herrera, nessas primeiras atividades, à implantação de novos instrumentos e novas máquinas, que facilitariam a execução da obra, principalmente para o levantamento das pedras ${ }^{59}$.

\footnotetext{
${ }^{57}$ LLAGUNO, Op. cit., vol. 2, p. 273. Apud. WILKINSON-ZERNER, C. Op. cit., p.14.

${ }^{58}$ TAVARES, D. Op. cit., p. 37.

59 NIETO ALCAIDE, V. M.; MORALES, A. e CHECA, F. Op. cit.

Há autores que se ocupam exclusivamente de estudar a preocupação de Herrera em relação às gruas, que eram instrumentos usados para se levantar pesos. No caso, para a construção de edifícios, esses instrumentos eram importantíssimos para se elevar as pedras. O desenvolvimento dessas máquinas foi fundamentais para que a obra do Escorial fosse concluída ainda durante o reinado de felipe II. Sobre o assunto podemos citar a obra:
} 
Nesse momento de formação prática de Herrera, cresceu também a confiança que o monarca lhe conferia. Da mesma forma, aumentavam as atribuições do jovem aprendiz. Nesse processo, Felipe II passou a pedir cópias dos desenhos de Toledo a Herrera e, a partir desses esboços, passaria a decidir o futuro da obra. Esse controle do rei em relação às obras do Escorial aparece explicitamente em Siguenza: "Mandaba S. M. que le avisasen de todo lo que se iba haciendo, y aún cuando se ofrecia cosa de poca importancia, le enviaban las trazas, los diseños y aún los modelos." 60

Durante o período de estado avançado da doença de Juan Bautista de Toledo, por volta de 1565, o papel do ajudante ganhava maior destaque. Em 1567, Juan de Toledo morreu e, apesar da crescente contribuição de Herrera nos rumos do projeto do Escorial, o monarca mostrou-se por algum tempo receoso em nomear o novo arquiteto real. Em carta régia de poucos meses antes da morte de Toledo, Felipe II aumentava substancialmente o salário de Herrera. Tal atitude se devia aos serviços que este desempenhava em lugar do arquiteto principal, durante a fase final de sua doença. Nesse mesmo documento, o rei chama-o de "Herrera arquitecto"61.

No entanto, se Herrera pretendia se tornar o substituto de Juan Bautista de Toledo, isso demoraria a acontecer. Em 1569 o prior do Escorial foi nomeado responsável por estas obras. Por volta desse mesmo período, Herrera efetuou vários trabalhos hidráulicos, juntamente com Juanelo Turriano, sendo que apenas em 1572 passou ao comando efetivo das obras arquitetônicas da coroa espanhola, função que se tornou oficial em 1579, com a confirmação de seu estatuto de "Arquitecto de Su Majestad" e com a incumbência das obras do Escorial. Ao qualificar Herrera, que estava sob o comando das obras do Escorial, o padre Siguenza escreve (ao longo dos relatos que faz do ano de 1575): "Juan de Herrera,

LORDA IÑARRA, J. Herrera y las grúas de la Basílica de El Escorial. In: Revistas de Obras Públicas. Madrid, n. 3367, p.81-104, agosto/junho 1997.

60 SIGUENZA, J. Op. cit., Discurso XII, p. 134.

${ }^{61}$ TAVARES, D., Op. cit., p. 37.

LLAGUNO, Op. cit., vol.2, p.274, Apud. WILKINSON-ZERNER, C. Op. cit. p. 15. 
que era el trazador principal, que entró en lugar de Juan Bautista de Toledo, hombre de gran ingenio, y que alcanço mucho en matematicas". ${ }^{6}$

Como Juan Baustista de Toledo, Herrera teve dois ajudantes para seus serviços como arquiteto do rei: Pedro del Yermo (seu sobrinho), que nunca chegou a ser arquiteto, e Francisco de Mora, que realizaria muitas obras para o Duque de Lerma, durante o reinado de Felipe III (1568-1621).

Em 1578, um ano antes da nomeação de Herrera como arquiteto de sua majestade, Jacopo da Trezzo, ourives do rei, desenhou uma medalha com retrato de Juan de Herrera com os dizeres: IOAN-HERRERA-PHIL-II-REG-HISPARQUITEC. Apesar desta iniciativa não ser oficial, sendo Jacopo de Trezzo amigo de Juan de Herrera e servidor de Felipe II, sua obra deve ter sido autorizada pelo monarca.

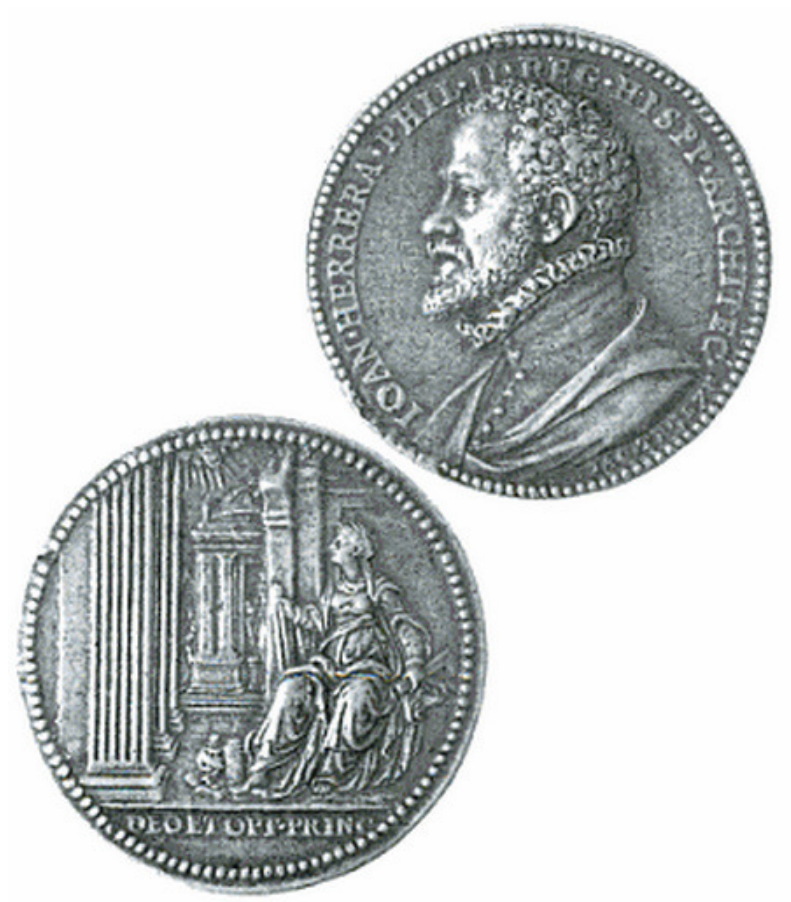

Figura 03 - Jacopo Trezzo, medalha em comemoração à Basílica do Escorial e nascimento de Felipe III, Madrid, 1578. Museu Arqueológico.

Fonte: WILKINZON-ZERNER, C. Op. cit. p. 17.

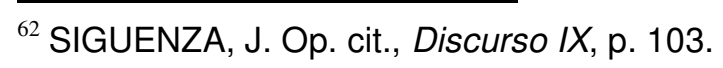


Segundo Wilkinson-Zerner ${ }^{63}$, nesse momento se consolidava na Espanha a visão albertiana sobre a relação entre rei e arquiteto. Segundo este modelo, deveria haver uma aliança intelectual entre estes dois sujeitos de um projeto arquitetônico: o arquiteto deveria ser versado na matemática e nos conhecimentos da antiguidade, e seu cliente ${ }^{64}$ deveria contribuir com discussões intelectuais sobre a arquitetura. Tal diálogo era possível devido ao vocabulário e conhecimento partilhados, que podiam ser adquiridos devido à circulação de textos sobre arquitetura. Certamente, o contato desde jovem com as idéias que circulavam na corte de Felipe II, ainda durante o período em que este governava como príncipe regente, deve ter proporcionado ao arquiteto uma série de conhecimentos e gostos em comum entre esse e o monarca ${ }^{65}$, o que teria facilitado a gestação desse modelo na Espanha.

Quando Herrera se insere nas atividades ligadas ao campo que hoje compreendemos ser da arquitetura, não existia propriamente a figura do arquiteto na Espanha. A edificação se realizava sob uma rígida hierarquia chefiada pelos "maestros mayores". Este profissional se ocupava de desenhar, planejar e selecionar seus representantes para supervisionar as obras em seu lugar, ou podia fazê-lo pessoalmente. Eram também esses "maestros mayores" os responsáveis pela contratação daqueles que se ocupariam com a carpintaria, alvenaria, etc., bem como podiam empregar seu próprio dinheiro para a compra de materiais. Não eram, frequentemente, funcionários a serviço de um senhor, ou da coroa, mas trabalhavam

\footnotetext{
${ }^{63}$ WILKINSON-ZERNER, C. Op. cit.

${ }^{64}$ Deve-se apontar que a concepção de arquiteto no sentido vitruviano aparece na Espanha em 1526, a partir da impressão do livro de Diego de Sagredo, Medidas Del Romano, como aquele que é o principal "fabricador" e ordenador de edifícios, versado nas artes liberais, como um oficial liberal, que trabalham somente com o espírito e o engenho.

No entanto, o que predominava enquanto prática, nessa primeira metade do século $\mathrm{XVI}$, era o aprendizado "prático" daqueles que se ocupariam de traçar e realizar os edifícios, como ajudantes nos canteiros. Essas obras eram regidas por contratos idênticos aos medievais, com fixação muito clara dos valores empregados, dos ganhos e atribuições do "mestre mayor", sem considerar nenhuma dessas concepções da elevação do artista por seu engenho.

Contudo, mesmo para tratar das obras renascentistas, o termo empregado para designar aquele que encomenda a obra presente na bibliografia consultada continua a ser "cliente".
}

MARÍAS, F. El siglo XVI. Gótico y Renacimiento. Madrid: Silex, 1992.

${ }^{65}$ CAMARA MUÑOZ, A. Arquitectura y Sociedad en el Siglo de Oro. Madrid: Ediciones El Arquero Textos Universitários, 1990. 
para realizar um "produto" que depois Ihes traria retorno financeiro: o edifício. $O$ valor dessa obra era dado através da análise de outros "maestros mayores" que estavam encarregados de outras obras, ou seja, era uma profissão marcada pela auto-regulação. Todos os problemas entre mestres e clientes eram resolvidos através de uma reunião com outros mestres ${ }^{66}$.

Com os "maestros mayores", desenho e construção formavam um todo contínuo. Ou seja, o mesmo profissional encarregado de traçar o plano de um edifício permanecia supervisionando as obras até sua finalização. Quando Herrera passa a servir ao rei, como ajudante de Juan Bautista de Toledo, já estava se processando nos territórios pertencentes à Monarquia Hispânica uma distinção entre essas duas etapas da edificação: a primeira etapa referente à elaboração do projeto, e a segunda de coordenação e execução. $O$ que se percebia então era a função de traçar o edifício se separando das demais atribuições dos mestres ${ }^{67}$.

No entanto, não devemos ver tal mudança como concluída nesse momento. A nomeação de Herrera como arquiteto no século XVI ainda se configurava como uma exceção em relação ao contexto geral e às condições de atuação dos artistas na Espanha desse período. Também as concepções renascentistas, concretizadas em sua relação com Felipe II, apontavam para mais um momento de formação dessa nova imagem do arquiteto.

Neste contexto, Herrera passa a imprimir nos edifícios características que Ihes são associadas até hoje. Esse estilo, que vai se criando em sua carreira, é percebido mesmo nas obras realizadas com a contribuição de outros arquitetos, engenheiros e escultores. Os elementos desse estilo herreriano levam em conta sua preocupação com as proporções harmônicas, sempre procurando uma variedade de expressões para cada propósito de suas construções, a sobriedade de suas obras, pouco ornamentadas (frequentemente chamado de "estilo desornamentado") e com usos das ordens dórica (para os exteriores) e, mais

\footnotetext{
${ }^{66}$ Ibidem.

${ }^{67}$ MARÍAS, F. Op. cit.
} 
raramente, jônica. Isso se dá como sua defesa enquanto artista liberal, com formação teórica, pois suas obras tem uma grande preocupação matemática.

Nesse aspecto, o Escorial também é identificado com o arquiteto, ainda que não tenha sido realizado completamente sob as suas orientações e concepções. Herrera realizou uma série de desenhos que foram gravados por Pedro Perret sobre a construção do Escorial. Essas estampas contribuíram para que a imagem desse monastério fosse associada ao arquiteto ${ }^{68}$.

Percebemos, a partir desta obra, o surgimento de um artista reconhecido já em vida como seu construtor, o que aparece em alguns discursos do padre Siguenza, que elogia as boas escolhas ao longo das obras realizadas por Herrera:

"[Foi] la traza de Juan de Herrera tan buena, que dentro de un año subió por igual la fábrica de la iglesia en el contorno treinta piés en alto, que és, al suelo del coro y claustro, segunda planta y elección de toda esta fábrica con gran admiracion de todos y notable contento de S. M."

Sobre as obras de Herrera, podemos notar no mapa elaborado por Domingos Tavares (figura 4) onde se encontram suas principais intervenções na Península Ibérica, (excetuando-se as possíveis obras em Portugal).

Temos suas contribuições mais conhecidas, primeiramente, em Valladolid, onde Herrera realizou alguns planos para a Plaza Mayor e a Catedral. No Escorial, foi responsável pela finalização do Monastério de San Lorenzo el Real. Em Madrid, encontram-se suas contribuições na construção da ponte Segoviana e também alguns desenhos para as fachadas da Plaza Mayor. Em Toledo, realizou intervenções no Alcázar (escadaria principal e fachada sul), e atuou na realização da fachada do Ayuntamiento e na Plaza Zocodover. Em Aranjuez, contribuiu com desenhos para o palácio real (iniciado por Juan Bautista de Toledo e finalizado no reinado de Felipe $\mathrm{V}$ ). Por fim, como se encontra assinalado na figura 2, em Sevilha

\footnotetext{
${ }^{68}$ HERRERA, J. Sumário y breve declaraciõ delos diseños y estampas de la Fabrica de san Lorencio el Real del Escurial. Madrid: 1589. Apud. WILKINSON-ZERNER, Op. cit.

${ }^{69}$ SIGUENZA, J. Op. cit., Discurso X, p.110.
} 
realizou a planta da Lonja (casa dos mercadores), que hoje é a sede do "Archivo General de las Indias".

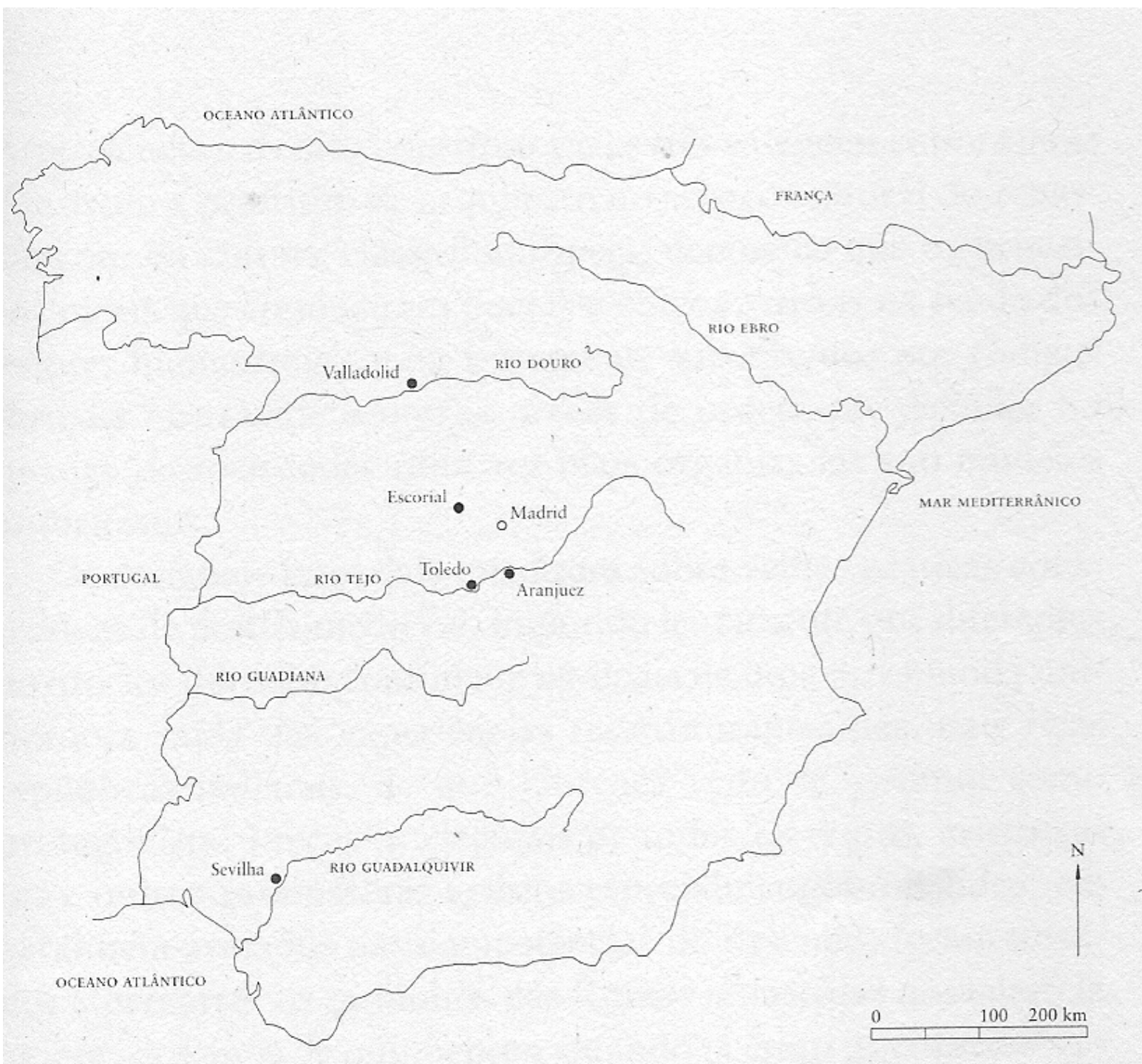

Figura 04 - Mapa elaborado por Domingos Tavares, com a localização das principais obras de Juan de Herrera.

Fonte: TAVARES, D. Op.cit., p.08.

As realizações de Herrera estão localizadas, sobretudo, próximas a Madrid e se relacionam ao programa de Felipe II de estabelecimento de residências reais e intervenções urbanísticas nesta cidade, Toledo e Sevilha. Nas palavras de Francisco Villalpando, em sua tradução do livro de Serlio dedicado a Felipe II, citadas no livro de Catherine Zerner-Wilkinson, os reis precisavam dos arquitetos para criar suas fortalezas em tempos de guerra e boas residências e 
jardins para o deleite em tempos de paz, além de serem os responsáveis por perpetuar a fama do príncipe em suas obras, porque "si leyendo una historia o coronica de un príncipe, paresce que en ella se oyen sus hechos, en la architectura se ven"70. Segundo Villalpando, suas pedras representariam a pessoa, a majestade, o pontificado e autoridade de seu fundador.

As obras enumeradas anteriormente começam a ser realizadas, sobretudo, a partir de 1559, quando o monarca inicia uma série de projetos arquitetônicos, que criariam a imagem que desejava para suas residências, segundo Catherine Wilkinson-Zerner.

A primeira intervenção a ser lembrada se encontrava muito próxima a Madrid, no palácio de Aranjuez, em uma área que era propriedade real desde os Reis Católicos (1474/9-1504). Já havia uma antiga residência que fora preservada, mas projetava-se uma nova, um palácio entre bosques. Juan Baustista de Toledo foi o primeiro a traçar o projeto que se desenvolveu. Herrera preservou o plano geral do arquiteto anterior, mas foi responsável por modificações radicais na fachada principal.

O Alcázar de Toledo também recebeu a atenção dos arquitetos a serviço do rei. Em 1537, Carlos V havia ordenado a Alonso de Covarrubias e Luis de Vega que o reconstruíssem, mas ainda permaneciam inacabadas a fachada sul e a escadaria principal, esta última desenhada por Covarrubias. No entanto, havia um espaço entre a escada e a fachada, segundo o plano, que impedia sua execução. Herrera foi o responsável por finalizá-lo, resolvendo o problema existente na traça anterior. Também a fachada sul foi finalizada por Herrera, o que explica porque ele é lembrado quando se trata desse edifício. Tal fachada não era a principal, mas era a mais visível aos que estavam à distância do Alcázar. Essa imagem do edifício aos seus observadores na cidade explica a preocupação e o cuidado que o arquiteto teve em garantir que seria visto pelos demais como uma expressão do poder real dentro da cidade de Toledo.

\footnotetext{
${ }^{70}$ VILLALPANDO, F. Sebastiano Serlio, tercero y quarto libro de architectura. Madrid, 1552. Edição Facssimile. Valencia: Albatro Ed, 1997, [s/n]. Apud. WILKINSON-ZERNER, C. Op. cit., p.69.
} 


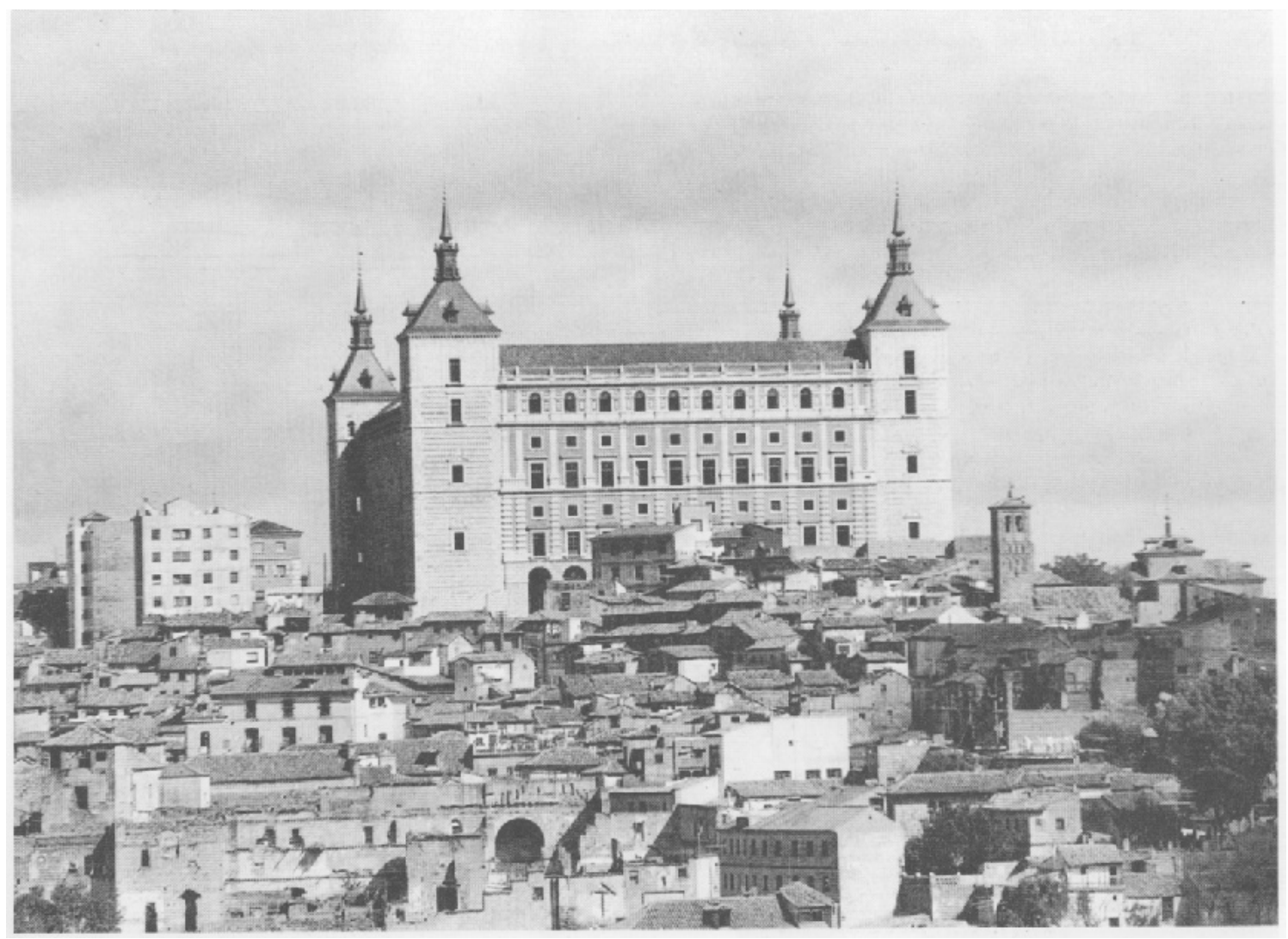

Figura 05 - Fotografia atual (sem autoria) com vista para a fachada sul do Alcázar de Toledo.

Fonte: WILKINSON-ZERNER, C. Op.cit., p.79.

O palácio de Carlos V, em Granada, foi mais uma das obras já existentes a serem modificadas no reinado de Felipe II. O palácio fora traçado por Pedro Machuca com a intenção de realizar, para o imperador do Sacro Império e rei da Espanha, um espaço construído a partir da linguagem italiana-renascentista. A construção se iniciou em 1533, sendo que após a morte desse arquiteto, seu filho, Luis, continuou-o de 1550 até 1571. As modificações realizadas por Herrera entraram em contraste com o projeto inicial de Machuca, pois aumentaram a altura do edifício e simplificaram sua fachada, deixando os ornamentos mais lisos. No entanto, não se realizaram muitos dos desenhos traçados por Herrera e o edifício permaneceu inacabado até o final do reinado de Felipe II.

Segundo Catherine Wilkinson-Zerner, apesar de não estar documentado, provavelmente Herrera participou do projeto de reconstrução do Palácio da Ribeira em Lisboa, que foi o último projeto palaciano de Felipe II e o mais ambicioso de Herrera para uma residência real. A torre que desenhou para esse 
edifício era muito mais alta e larga que as que se faziam em seu tempo. Segundo a autora: "Era tan clássico como el palácio Farnese de Piacenza, y más impressionante que las fachadas al río del Louvre." ${ }^{, 1}$

Entre seus serviços à coroa, Herrera também visitou Portugal em 1580, ajudando na preparação das instalações do rei e sua corte, para o tempo que permaneceriam em Lisboa. Segundo Domingos Tavares ${ }^{72}$, inúmeras vezes se buscou a autoria de Herrera em construções feitas nessa cidade por ordem de Felipe II, o que parece não ter ocorrido, pois, nesse período anterior às entradas régias em Portugal, o arquiteto viajava constantemente para a Espanha a fim de acompanhar o desenvolvimento das obras do Escorial e do palácio e jardins de Aranjuez, contradizendo a opinião de Wilkinson-Zerner, que apontamos anteriormente.

Também, a fachada do Ayuntamiento de Toledo e a Lonja de Sevilha tiveram a intervenção de Herrera. No Ayuntamiento, o arquiteto seguiu a linguagem do Escorial, tanto no estilo rústico, quanto nos materiais utilizados e na forma de execução. A Lonja era um edifício civil, espécie de armazém que, apesar de ter sido financiada pelos comerciantes da cidade, a partir de 1598 passou a ser um empreendimento real. A partir dos planos de Herrera a Lonja se tornou um edifício italianizante.

Dentro da carreira de Juan de Herrera, a viagem a Portugal em 1580 teve inúmeras conseqüências. Alguns autores consideram que Felipe II, sabendo que precisaria se ausentar de Madrid, devido à necessidade de permanecer por algum tempo em visita a Portugal, teria finalmente se decidido a dar o título de "Arquitecto de Su Majestad" a Herrera, o mais alto cargo que este poderia ter desejado atuando na arquitetura régia. Dessa forma, abandonava definitivamente a tradição medieval dos "maestros mayores", e o rei também contaria com um responsável por tomar decisões no que diz respeito aos seus planos construtivos ${ }^{73}$.

\footnotetext{
${ }^{71}$ WILKINSON-ZERNER, C. Op. cit., p.83.

72 TAVARES, Op. cit., p.45.

${ }^{73}$ Wilkinson-Zerner, C. Op. cit.
} 
Desta viagem também surgiu, provavelmente, a intenção de se criar a Academia de Matemáticas, inspirada na instituição portuguesa voltada ao ensino matemático aos técnicos do reino, que trataremos a diante.

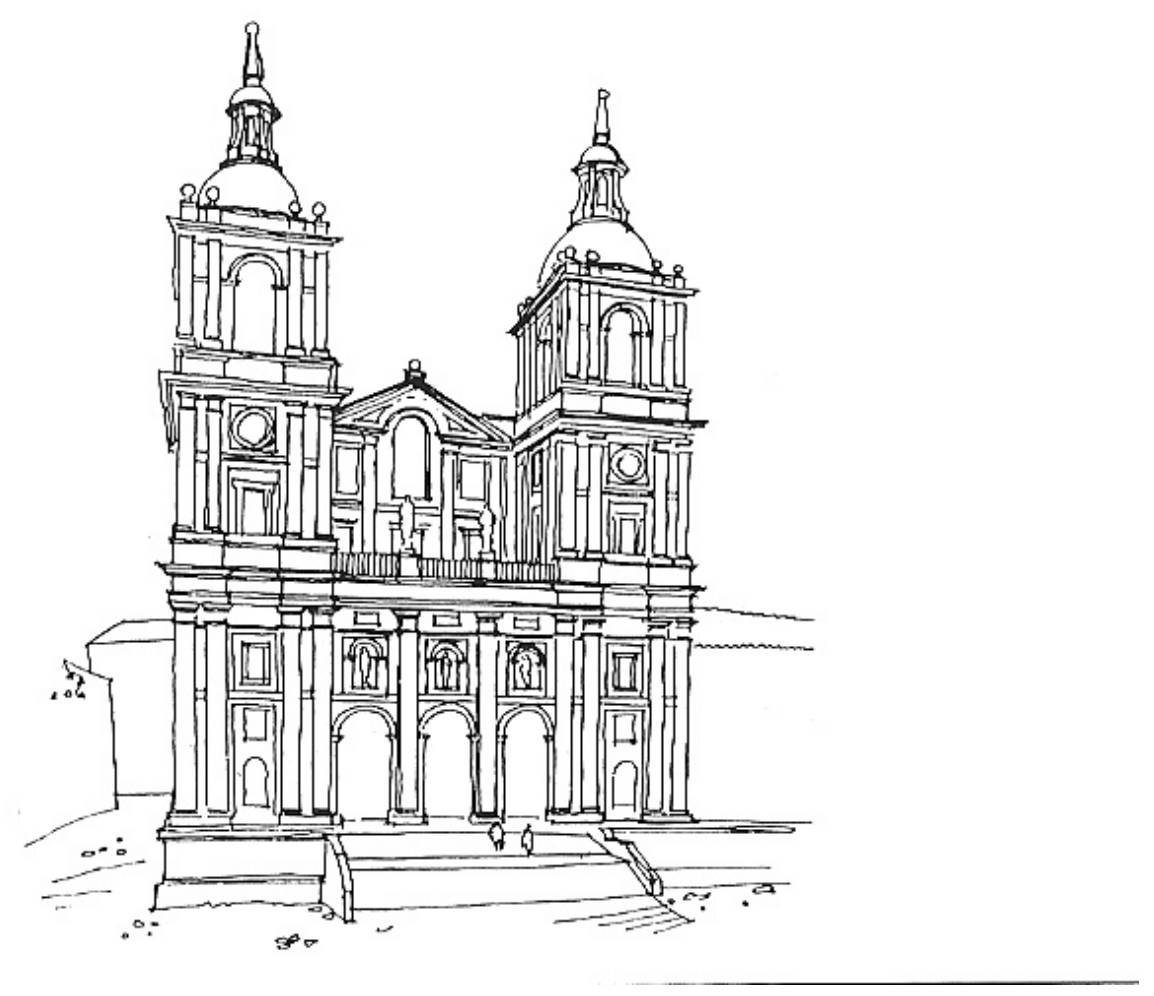

Figura 06 - Fachada que supostamente teria influencia herreriana, realizada no período de União das Coroas Ibéricas: São Vicente de Fora - Lisboa

Fonte: HIGUERA, M. A., GÓMEZ MARTíNEZ, J. Op. cit., p.192.

O principal projeto de Herrera pode ser considerado a Catedral de Valladolid, desenhada em 1585. Consiste em uma igreja retangular simétrica, com cúpulas eqüidistantes aos finais do retângulo, que são marcados por torres de canto. Esses dois projetos, o Escorial e a Catedral de Valladolid, tonariam-se o modelo da arquitetura de Herrera a ser imitado.

Em 1588, Juan de Ribeiro Rada abandona o projeto original da Catedral de Salamanca para seguir o modelo de Herrera. Outros planos também são alterados conforme o plano de Valladolid, sendo que nas colônias americanas as catedrais do México, Puebla e Lima seguem o mesmo destino. A Igreja de Pilar, em 
Saragoça, o mais importante plano de igreja do século XVII na Espanha, segundo George Kluber $^{74}$, seria outro a se alterar para o modelo herreriano. Também dentre aqueles que se inspiraram no "estilo desornamentado", ao longo da primeira metade do século XVII, teríamos, sobretudo na Andaluzia, a influencia de Herrera nas obras de Bartolomé Bustamante e Hernán Ruiz.

Para Catherine Wilkinson-Zerner, o significado da Catedral de Valladolid é o de um projeto que em muitos aspectos se apresentava como gótico. Essa interpretação vai de encontro a uma das questões levantadas por Fernando Marias, que considera que na Espanha do século XVI os arquitetos utilizavam-se em seus projetos ora dos elementos góticos, ora dos elementos italinizantes. Para Marias, o gótico associava-se, sobretudo, ao pertencimento religioso e à tradição anterior $^{75}$.

Herrera preparou desenhos para a Catedral de Valladolid entre 1578 e 1582, quando se iniciaram as modificações no edifício já existente. Algumas das características escolhidas para a Igreja seguiam as resoluções apresentadas pelo Concílio de Trento, como deixar o Sagrado Sacramento visível aos fiéis. Para Wilkinson-Zerner, Herrera adotou o estilo gótico para a obra depois de uma longa discussão com os religiosos que o requisitaram. Pedir ao arquiteto que tinha auxiliado na finalização do Escorial para planejar aquele edifício significava o desejo de se ligar ao estilo clássico. Porém, o que já estava construído para essa catedral era gótico e continuar a obra em um estilo mais moderno comprometia a unidade. Não é possível definir quem decidiu pelo estilo a ser seguido, mas a elaboração a partir dessa eleição foi completamente de responsabilidade de Herrera.

Os autores não concordam acerca do estilo e do significado da Catedral de Valladolid. Para Checa, as soluções empregadas nessa obra, em resumo, trouxeram contribuições na teoria das proporções, sobre a perfeita volumetria, a questão do respeito ao muro e, ainda que o projeto herreriano para

\footnotetext{
${ }^{74}$ KUBLER, G. Art and Arquitecture in Spain and Portugal and Their American Dominions (1500 to 1800). Bradford: Penguin Books, 1959.

${ }^{75}$ MARIAS, F. Op. cit., p.09.
} 
essa obra não tenha sido finalizado, ficou como o principal exemplo do classicismo espanhol. Como coloca: "en la Catedral de Valladolid nos encontramos ante uno de los mejores ejemplos de aplicación de la teoría renacentista de las proporciones que podamos estudiar en el siglo XVI español."76

As mudanças que ocorrerem na arquitetura espanhola em meados do século $\mathrm{XVI}$, segundo Fernando $\mathrm{Checa}^{77}$, marcam a passagem de um grande experimentalismo, para uma grande austeridade e pragmatismo, sobretudo com os traçados de Herrera. Tal mudança se dá não apenas pela repercussão da obra do Escorial, mas pela mudança da mentalidade da época, muito mais preocupada em propagar as idéias da Contra-Reforma. Inclusive, em 1582, o Concílio Provincial de Toledo deu origem a toda uma série de Constituições Sinodais que trataram de aplicar o novo rigor à arquitetura.

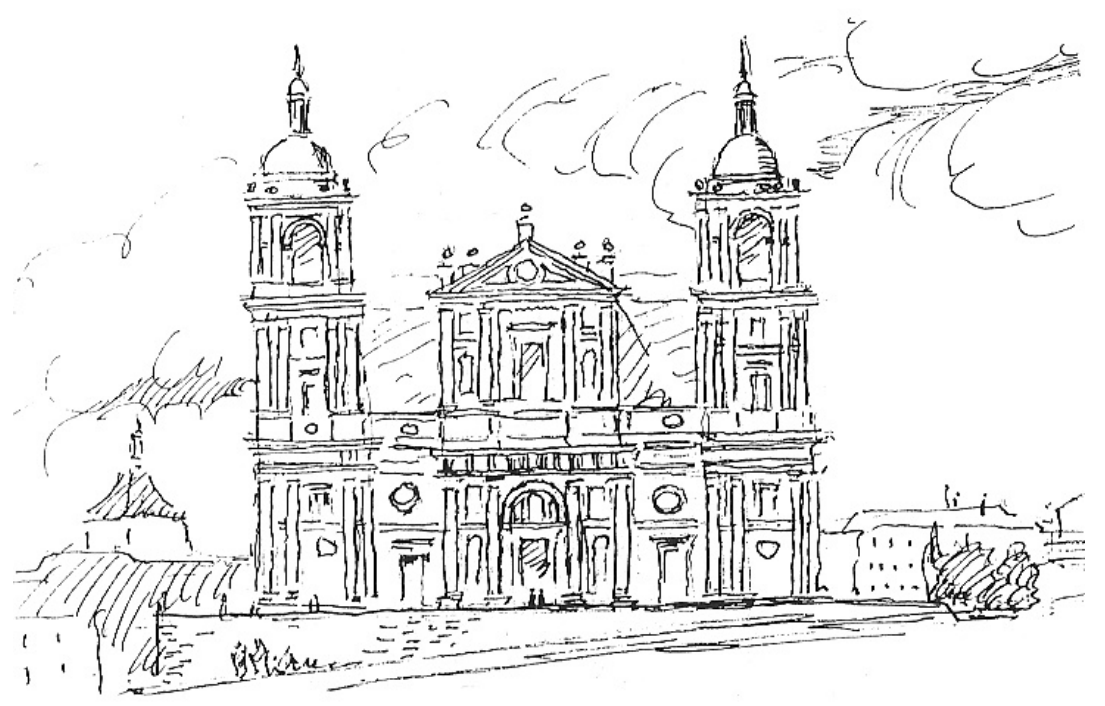

Figura 07 - Fachada da Catedral de Valladolid

Fonte: HIGUERA, M. Á. , GÓMEZ MARTÍNEZ J., Herrera y su influencia: actas del simposio, Camargo, 14-17 julio 1992. Santander: Ed. Universidad de Cantabria, 1993, p. 191.

\footnotetext{
${ }^{76}$ NIETO ALCAIDE, V. M.; MORALES, A. e CHECA, F. Op. cit., p.353.

${ }^{77}$ Ibidem.
} 


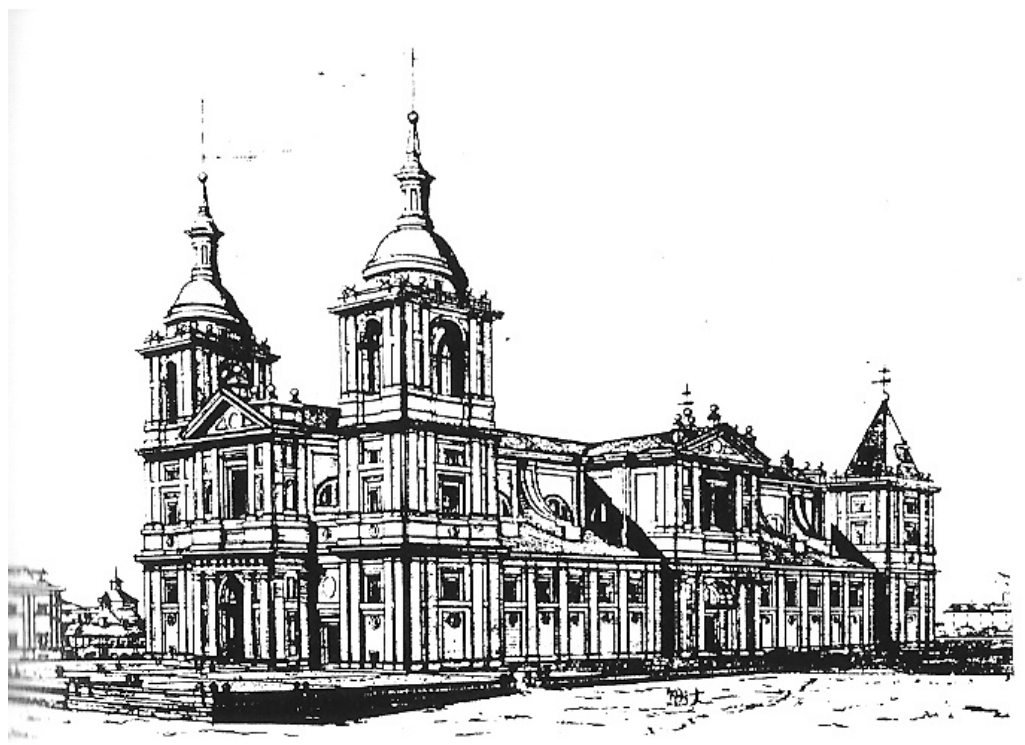

Figura 08 - Catedral de Valladolid em perspectiva.

Fonte: HIGUERA, M. A., GÓMEZ MARTíNEZ, J. Op. Cit., p.191.

Além disso, com o incentivo de Herrera, o debate teórico sobre a arquitetura é elevado a um nível muito superior ao alcançado anteriormente, o que pode ser percebido principalmente pela sua importância na criação da Academia de Matemática, que trataremos adiante.

Através desses serviços à coroa, Juan de Herrera conseguiu manter-se na corte e utilizar as vantagens de sua proximidade em relação ao monarca. Assim, conseguiu valiosas heranças nos dois casamentos que teve. Até seu primeiro casamento, em 1571, manteve relações com uma mulher chamada Juana Martínez, com quem teve uma filha ilegítima, Luísa. Herrera deu a esta filha seu sobrenome e um bom dote para contrair casamento. Sua primeira esposa foi María de Álvaro, herdeira dos bens de seu pai, Pedro de Álvaro e viúva de Juan de Landa, ambos com negócios em Madrid. Desse matrimônio recebeu uma considerável herança, em 1576, incluindo uma propriedade de terra, o que lhe possibilitou ajudar Luísa e comprar os bens de seus pais. Herrera e María não tiveram filhos. ${ }^{78}$

${ }^{78}$ Os testamentos de Juan de Herrera que contém tais informações fazem parte da coleção de documentos reunida por Luis Cervera-Vera: 
Seu segundo casamento foi com Inez, filha de Marcos de Herrera, representante do ramo mais antigo de sua própria família, aqueles que tinham herdado os títulos e bens de seu avô. Em 1586, Marcos de Herrera faleceu deixando à Inez seus títulos. Desse casamento nasceram seis filhos: Lorena (1584), Úrsula (1587), Luisa (1590), Petronila (?), Catalina (1592) e um filho, Juan (1594). Inês morreu ao nascer seu filho homem, que se tornara então herdeiro dos títulos familiares. Porém, a criança apenas viveu um ano, deixando sua herança ao pai.

Segundo Wilkinson-Zerner, era uma das principais preocupações do arquiteto manter essa posse fundiária como símbolo de sua origem nobre:

"A su muerte, Herrera contaba aproximadamente con 37.000 ducados. Poseyó una cadena de oro (probablemente regalo del rey) que por si sola valía más que las tierras de su padre y la casa. Pero Maliaño representaba la dignidad. Esas tierras sin provecho en una remota provincia eran un punto de referencia en una sociedad llena de gente de esa misma clase. Maliaño era el símbolo de respetabilidad de Herrera, que lo distinguía de la masa de individuos desarraigados que trataban de sobrevivir, en su mayoría mediante el ejército." ${ }^{, 79}$

Também conseguiu uma importante renda garantida com as minas de sal de Cuenca, após reclamar uma recompensa por seus serviços à coroa. Conseguiu o morgadio e o título de corregedor de Santander, o que the conferiu conforto ao final de seus dias. Entretanto, os gastos com a vida na corte e com os serviços prestados ao rei não possibilitavam que fosse considerado um homem de grande riqueza ${ }^{80}$.

Após sua morte em janeiro 1597, aos sessenta e seis anos, devido ao desconhecimento do paradeiro de suas filhas, seu patrimônio destinou-se à instituição da "Fundación Obra Pia de Juan de Herrera", juntamente com a construção da capela de San Juan no local em que se encontrava a casa do arquiteto, para onde seu corpo foi trasladado em fins do século XVII e que existe

CERVERA-VERA, L. Collección de documentos para la historia del arte en España. MadridZaragoza: [s/n], 1981-7. Apud. WILKINSON-ZENER, C. Op. cit., p.09.

\footnotetext{
${ }^{79}$ WILKINSON-ZERNER, C. Op. cit. p.09

${ }^{80}$ Ibidem.
} 
ainda hoje em sua cidade natal, Maliaño, localidade do Município de Camargo, na região da Cantábria.

Depois de traçarmos nessas páginas a trajetória de Juan de Herrera, colocaremos algumas considerações presentes na bibliografia que demonstram diferentes visões acerca da importância do arquiteto. 


\subsection{Juan de Herrera e sua fortuna crítica}

"Juan Gris, és o executor categórico do Discurso sobre a forma cúbica de Juan de Herrera, arquitecto de Felipe II da Espanha. O Escorial, como tu, é o realismo e o misticismo feitos arquitetctura. Juan Gris, me agradas muito! Com Seurat, és o mais clássico dos modernos."

Salvador Dali ${ }^{81}$

De diferentes maneiras e motivos diversos, algumas personagens são retomadas ao longo do tempo, seja para se diferenciarem, superá-las, ou tomálas como exemplos a serem seguidos. Ver nas palavras de Salvador Dalí, escritas em 1956, o nome de Herrera ser utilizado para exaltar Juan Gris, nos faz pensar nos motivos que fizeram este arquiteto de Felipe II ser lembrado por tantas gerações.

Memória e esquecimento são fatores importantes para se perceber como são construídas interpretações baseadas nos feitos, escritos e idéias de homens que tiveram papel fundamental na elaboração de determinados conhecimentos científicos, artísticos, políticos, etc. A História frequentemente retoma algumas personalidades, as coloca no esquecimento, ou modifica a maneira de interpretá-las. Também, conforme novos documentos, antes pouco valorizados, passam a ser considerados fontes históricas, ricas e dignas de serem interpretadas, novos elementos tornam-se acessíveis aos historiadores e novas questões passam a ser propostas. Todas essas considerações nos ajudam a perceber que devemos ter em mente como as personagens que estudamos já foram vistas anteriormente, e em qual lugar se insere a nossa questão acerca desse(s) homem(s) do passado. Assim, apresentamos brevemente a fortuna crítica de Juan de Herrera, segundo alguns autores da bibliografia consultada.

\footnotetext{
${ }^{81}$ DALÍ, S. Libelo contra a arte moderna. Trad. Paulo Neves. Porto Alegre: L\&PM Pocket, 2008.
} 
Herrera é um dos poucos arquitetos espanhóis cuja obra é rapidamente lembrada por sua autoria. Depois de Felipe II, seu nome é o mais conhecido quando se trata dos resposáveis pela construção do Escorial, paláciomonastério que integra o conjunto dos patrimônios culturais da humanidade na Espanha atualmente. Essa obra, como já mencionado, não foi o resultado dos serviços exclusivos de Juan de Herrera.

O Escorial é, ainda hoje, um dos grandes símbolos do poder real espanhol legados pelo passado. Quando Salvador Dalí cita o homem e sua obra, está se referindo a mais do que um edifício entre tantos outros dignos de serem lembrados e valorizados como patrimônios ibéricos. Dalí dialoga com a tradição, com a imagem que ainda se transmitia daquele imponente edifício, o que representavam aqueles altos muros aos artistas da passagem do século XIX para o XX.

A imagem do reinado dos Habsburgos na Espanha, como um tempo em que a religião católica foi reafirmada e fortalecida como parte integrante do poder real, estava expressa no Escorial. A idéia de como tinham sido apropriados os elementos clássicos pela arte espanhola dos séculos XVI e XVII estava ali concretizada. Poder, religião e classicismo - essa relação que se estabeleceu em outros momentos da história espanhola, tinha como referência imagética o paláciomonastério repousado no relevo também austero da Serra da Guadarrama, nas proximidades de Madrid. Essa relação estava presente e era uma referência para os artistas modernos, como Dalí. Décadas antes, Herrera, entre outros homens que se apropriaram do pensamento humanista entre os séculos XV e XVII, foram retomados por defensores da cultura e das produções teóricas e materiais dos "espanhóis" ${ }^{2}$.

Os intelectuais espanhóis, de finais do século XIX e início do XX, retomaram os anos áureos do reinado de Felipe II para repensar a Espanha que acabava de perder sua última colônia, Cuba, em 1898. Nesse momento, o país encontrava-se efervescente em função dos movimentos separatistas, que ganhavam

\footnotetext{
${ }^{82} \mathrm{O}$ termo aparece aqui entre aspas para marcar a dificuldade e a artificialidade (ainda que esse adjetivo também merecesse uma discussão) da construção de uma unidade/identidade em relação ao "ser espanhol".
} 
força questionando a unidade que fora adquirida, em muitos momentos, de forma delicada e instável ${ }^{83}$. Um exemplo desse esforço encontra-se nos escritos de Miguel de Unamuno, que retomava o tema do Dom Quixote, de Cervantes, e da ligação entre catolicismo e governo em seu ensaio "El cabalero de la triste figura" ${ }^{44}$.

Segundo Lópes Piñero, Navarro Brotons e Marco Portela ${ }^{85}$, essas discussões se iniciam no século XVIII, sobretudo a partir do questionamento sobre a relevância espanhola para o desenvolvimento científico europeu. Este debate, especificamente, ficou conhecido como "polêmica das ciências espanholas" e foi impulsionado pela publicação da "Encyclopédie Méthodique" com o artigo "Espagne", de Nicolas Masson de Morvilliers, em $1782^{86}$. O autor atacava a censura e a inquisição na Espanha como elementos que barraram a possibilidade de uma revolução científica em seu território. Nas palavras de Morvilliers:

"L' Espagnol a de l'aptitude pour les sciences, il a beaucoup de livres, \& cependant, c'est peut-être la nation la plus ignorante de l'Europe. Que peut-on espérer d'un peuple qui attend d'un moine la liberté de lire \& de penser?" ${ }^{87}$

No trecho, percebemos claramente que o entrave identificado por Masson para as ciências espanholas estava no controle da Igreja sobre o saber. As

\footnotetext{
${ }^{83}$ CAPELATO, M. H. R. A data símbolo de 1898: o impacto da independência de Cuba na Espanha e Hispanoamérica. In: História, vol.22, no.2, Franca, 2003, pp. 35-58.

${ }^{84}$ UNAMUNO, M. El caballero de triste figura.(1896) In: idem. Ensaios. Madrid: Aguiar, 1958.

${ }^{85}$ LÓPEZ PINERO, J. M.; NAVARRO BROTONS, V.; PORTELA MARCO, E. La actividad científica y tecnológica. In: ARTOLA, M. (dir). Enciclopedia de Historia de España. Vol. III: Iglesia.

Pensamiento. Cultura. Madrid: Alianza, 1988, pp. 273-325.

${ }^{86}$ Consultamos a transcrição do verbete, realizada a partir da edição presente na Biblioteca Saavedra Farjano, por Victor Cases Martínez:
}

MORVILLIERS, N. M. de. Espagne. In: Encyclopédie méthodique ou par ordre des matières. Géographie moderne. Vol. I. París: Pandoucke, 1782, p. 554-568. Apud: CASES MARTINEZ, V. La polémica España de Masson de Morvilliers. In: idem (ed.). La España de la Encyclopédie méthodique de 1782. Murcia: Biblioteca Saavedra Farjano, 2010, pp.03-33.

\footnotetext{
87 "O espanhol tem aptidão para a ciência, possui muitos livros, e, no entanto, é talvez a nação mais ignorante da Europa. O que se pode esperar de um povo que precisa pedir licença ao frei para poder ler e pensar?"
}

Ibidem, p.25. 
primeiras respostas contrárias a esse texto estavam carregadas de nacionalismo, no caso de Antonio José Cavanilles ${ }^{88}$, ou comprometidos com a defesa do Estado Absolutista, no caso de Carlo Denina ${ }^{89}$. Os textos de Cavanilles e Denina foram escritos na França e rapidamente traduzidos para o espanhol.

A resposta "oficial" espanhola a esse artigo se deu através de um concurso, promovido pela Real Academia, que se dirigia àqueles que desejassem escrever um elogio à Espanha, tomando como referência seus grandes escritores, matemáticos, filósofos, artistas, seus progressos científicos, etc. Esse concurso foi vencido por Juan Pablo Forner ${ }^{90}$. Dessa forma, segundo Lopes Piñeiro, a discussão tinha como pano de fundo a disputa entre uma França que se afirmava positivista, e a Espanha, que se encontrava ligada à tradição católica criticada pelos seus vizinhos do norte: "La tradición científica española fue una mera excusa para el enfretamiento de la ideologia conservadora, clerical y casticista con la mentalidad positivista, progresista y laica" ${ }^{\text {"91. }}$

Numa segunda fase dessa discussão, iniciada em meados de 1876, nomes como Marcelino Menéndez Pelayo, Gumersindo Laverte e Alejandro Pidal defenderam a ciência espanhola, enquanto Manuel de la Revilla, José del Perojo e Gumersindo de Azcárate denunciavam o atraso devido à estrutura política absolutista. Nesse cenário, Menéndez Pelayo ${ }^{92}$ prepara um inventário bibliográfico

\footnotetext{
${ }^{88}$ Antonio José Cavanilles, que era um respeitado botânico espanhol, residente em Paris há alguns anos no momento da publicação da Encyclopédie, escreveu na França seus comentários sobre o artigo em defesa da Espanha:
}

CAVANILLES, A. J. Observaciones sobre el artículo "España" de la Nueva Enciclopedia. Trad. Mariano Rivera. Madrid: Imprenta Real, 1784.

${ }^{89}$ DENINA, C. Respuesta a la pregunta: ¿Qué se debe a España?. Trad. Manuel de Urqullu. Cádiz: Imprenta de Manuel Ximénez Carreño, 1786.

${ }^{90}$ FORNER, J. P. Oración apologética por la España y su mérito literario, para que sirva de exornación al discurso leído por el abate Denina en la Academia de Ciencias de Berlín, respondiendo a la qüestion qué se debe a España?. Madrid: Imprenta Real, 1786.

${ }^{91}$ LÓPEZ PINERO, J. M.; NAVARRO BROTONS, V.; PORTELA MARCO, E. La actividad científica y tecnológica. In: ARTOLA, M. (dir). Enciclopedia de Historia de España. Vol. III: Iglesia. Pensamiento. Cultura. Madrid: Alianza, 1988, pp. 273-325.

\footnotetext{
${ }^{92}$ Marcelino Menendez y Pelayo nasceu em Santander em 1856, onde também faleceu em 1912. Foi crítico literário, professor catedrático de Literatura na Universidade Central de Madrid, membro da Real Academia Espanhola, da Real Academia de História, da Academia de Ciências Morais e
} 
da ciência espanhola, que identificava sua visão da ciência como as obras das "grandes figuras". Para responder às criticas sobre o atraso espanhol, o autor retomou a figura de Juan de Herrera para revalorizar a cultura espanhola, em sentido amplo, da filosofia às obras de "ciência"93.

Considerando esse retorno à História Moderna, empreendido pelos intelectuais espanhóis do século XIX, temos algumas pistas do motivo que fez Herrera ser lembrado por algumas das obras significativas que realizou no reinado de Felipe II. Mesmo não sendo o construtor único do Escorial, Herrera, diferentemente de muitos outros colaboradores da coroa, era um homem muito próximo ao monarca e que produziu outras obras escritas, participando ativamente da tentativa de desenvolver o estudo das matemáticas no reino, como apontaremos adiante.

Relembrando as palavras do historiador da obra do Escorial, padre José de Siguenza, quando trata da substituição de Juan Baustista de Toledo, que havia morrido, por Juan de Herrera: "(...) se juntaron Juan de Herrera, que era el trazador principal, que entro em lugar de Juan Bautista de Toledo, hombre de gran ingenio, y que alcanço mucho em matemáticas" ${ }^{\prime \prime}$. Esse trecho nos aponta a percepção do padre historiador em relação às questões da construção do edifício, o que aparece em outros elogios do padre às escolhas técnicas empreendidas por Herrera, que teriam viabilizado a conclusão da obra ainda durante o reinado de Felipe II.

Políticas, da Academia de Belas Artes de San Fernando, e Diretor da Biblioteca Nacional Espanhola. Possui obra extensa e muito variada. Sua biblioteca pessoal, com mais de 42.000 livros, reunida desde a infância, foi doada ao Ayuntamiento de Santander, sendo que algumas obras, inclusive, encontram-se digitalizadas e disponíveis pela internet ao público.

http://www.bibliotecademenendezpelayo.org

${ }^{93}$ MENENDEZ PELAYO, M. La ciencia española: polémicas, indicaciones y proyectos. Alicante: Biblioteva Virtual Miguel de Cervantes, 1999. Edição digital baseada na 2a edição de Madrid, Imprenta Central a cargo de Victor Saiz, 1879. Disponível na web em : http://www.cervantesvirtual.com/FichaObra.html?Ref=2032 Acesso em 20 de fevereiro de 2010.

${ }^{94}$ SIGUENZA, J. Op. cit, Discurso IX, p. 103. 
Apesar de estar entre os principais nomes das artes na Espanha e de sua proximidade com o monarca, seus contemporâneos lhe dedicaram poucos comentários. O historiador de Felipe II, Cabrera de Córdoba ${ }^{95}$, considerava Juan de Herrera um "charlatão". Devido às preocupações do rei com colecionismo, arquitetura, matemáticas, engenharia, etc ${ }^{96}$., Herrera desempenhava 0 papel de consultor para o monarca em assuntos relacionados à publicação de novos tratados. Também incentivava novos inventores de máquinas, e isso implicava em investimentos da coroa em projetos que nem sempre traziam bons resultados. Pelos fracassos levados a cabo pela influência do arquiteto real, Cabrera de Córdoba o culpava por apoiar projetos que apenas gastavam as finanças da coroa.

Além dos comentários de Cabrera de Córdoba e de José de Siguenza, não há escritos em sua época que procurassem registrar a vida de Herrera ${ }^{97}$. Podemos justificar essa ausência pelo fato de que a escrita de vida de artistas não era consagrada na Espanha como um gênero literário. Diferentemente, na Itália esse gênero tinha como principal referencia Giorgio Vasari (1511-1574), que escreveu "Le vite de' più eccellenti pittori, scultori e architettori" ("As vidas dos mais excelentes pintores, escultores e arquitetos"), publicada originalmente em duas edições, de 1550 e 1568, que é conhecida simplesmente como "Vidas dos artistas" ${ }^{\prime \prime 8}$. Entre outros aspectos, a arquitetura que se realizava e que buscava se

\footnotetext{
${ }^{95}$ Luis Cabrera de Córdoba (1559-1623) é conhecido por seus escritos como historiador do reinado de Felipe II. Filho de família nobre, descendente em linha direta dos condes de Torres Cabrera, nasceu em Madrid. Sua família se dedicava à carreira das armas, o que também seguiria. Estudou em "Colegios las Ciencias Liberales". Em 1584 vivia em Nápoles, com o Duque de Osuna, e apenas volta à Espanha para dar notícias ao rei sobre um tumulto que ocorrera em Nápoles em 1585, momento em que se deu sua visita ao Escorial. Foi como um "embaixador" de Felipe II, e destes serviços ao monarca pôde acumular uma infinidade de anotações sobre o funcionamento desse reinado, a partir das quais escreveu sua obra mais conhecida "Historia de Felipe II, Rey de España", impressa em 1619.
}

GARCÍA CÁRCEL, R. Felipe Il y los historiadores del siglos XVII. in: BENNASSAR PERILLIER, B.; et. al. Vivir el Siglo de Oro. Poder, Cultura e História en la época moderna. Estudios en homenaje al profesor Ángel Rodríguez Sánchez. Salamanca: Universidad de Salamanca, 2003, pp.285-316, p.298.

${ }^{96}$ LÓPEZ PINERO, J. M.; NAVARRO BROTONS, V.; PORTELA MARCO, E. Op. cit.

${ }^{97}$ CÁMARA MUÑOZ, A. Op. cit.

${ }^{98}$ VASARI, G.(1550/1568) Vidas dos Artistas. Trad. Ivone Castilho Benedetti. São Paulo: Martins Fontes, 2011, $1^{\underline{a}}$ ed. 
consolidar nesse momento na Espanha, com a figura de Herrera, não se apoiava na figura do arquiteto como dotado de liberdade. Acima dele estava a imagem do rei.

Frei José de Siguenza, em sua obra História primitiva y exacta del monasterio del Escorial, coloca Juan Bautista de Toledo como o construtor versado na concepção de Vitrúvio sobre a arquitetura. Herrera é mencionado como fundamental para a finalização do projeto, mas em nenhum momento o frei historiador se ocupa em fazer grandes elogios aos seus serviços, a não ser em suas qualidades "técnicas" e matemáticas, como mencionado. Herrera aparece como mais um dos nomes que contribuíram nesse projeto, com destaque para suas funções em algumas passagens dessa obra. A única personagem que sobressai efetivamente, nessa história do monastério, é o próprio rei, ao lado dos religiosos da ordem de São Jerônimo. Nesse sentido, como bem coloca Paolo Rossi, "A memória (como bem sabia David Hume) sem dúvida tem algo a ver não só com o passado, mas também com a identidade e, assim (indiretamente), com a própria persistência no futuro." 99 . Os documentos revelam o que se desejava que permanecesse no tempo - um rei autor, como veremos adiante.

Ainda sobre os antecedentes dessa re-valorização da figura de Juan de Herrera, inaugurada pela "polêmica das ciências espanholas", Kluber aponta que os seguidores do modelo de Herrera não mantiveram suas características por muito tempo:

"But Herrera's own harmonic manner had no sucessful imitators. A Romantic critic made the point in 1829 when he is referred to the inimitable character of Herrera's style, inimitable because founded upon 'obscure and metaphysical principles that are inacessible to person not endowed with similar gifts of temperament."100

\footnotetext{
${ }^{99}$ ROSSI, P. Op. Cit., p.24.

100 "Mas a forma harmônica própria de Herrera não teve imitadores bem sucedidos. Uma crítica romântica marcou 1829, quando se referiram ao estilo de Herrera como inimitável, porque se fundava em 'princípios obscuros e metafísicos' que são inacessíveis às pessoas que não são agraciadas com um presente similar de temperamento."
}

KUBLER, G. Op. cit., p.15. 
Ainda que tenhamos apontado anteriormente como alguns projetos foram modificados, após a realização da traça de Herrera para a Catedral de Valladolid, para que se aproximassem do realizado pelo arquiteto real, a continuidade de sua influencia na arquitetura teve o limite marcado por Kubler.

É importante salientar que a própria designação do estilo de Herrera como "desornamentado", surge como uma crítica. Tal definição é datada de 1879 e seu formulador foi Carl Justi, estudioso alemão da arte espanhola, portuguesa e italiana do Renascimento, autor, entre outras obras, de estudos sobre Diego Velázquez e seu tempo ${ }^{101}$. Para Justi, apesar dos contemporâneos de Herrera terem qualificado seu estilo como dotado de uma nobre simplicidade, sua arquitetura era destituída de imaginação e expressão pessoal. Tratava-se de uma arquitetura pedante, que apenas se referia à Vitruvio e Vignola. Também criticava o excesso de controle desempenhado por Herrera ao longo da construção dos edifícios ${ }^{102}$.

A partir dessas considerações, podemos entender quais são as referências tomadas pela historiografia nas últimas décadas para interpretar a importância de Juan de Herrera. Mencionando Geoffrey Parker ${ }^{103}$, percebemos que por muito tempo ficou presente na historiografia a imagem de Felipe II como um rei controlador, que conseguia demonstrar seus interesses e realizar sua política interferindo em todos os campos administrativos de seus territórios; um rei burocrático, que controlava através dos papeis os mais longínquos domínios. Os grandes inimigos do monarca, segundo Parker (concordando com a afirmação feita anteriormente por Braudel), eram a distância e o tempo necessários para que as informações chegassem ao centro de poder, para que as decisões fossem tomadas pelo monarca, ou, ao menos, com seu consentimento.

Geoffrey Parker trata com muito cuidado as várias facetas do monarca, da educação de Felipe II aos seus anos de crise, e a imagem que deixou aos seus contemporâneos. Quando trata dos momentos de divertimento do rei, que

\footnotetext{
101 JUSTI, C. Velázquez y su Siglo. Trad. Karin Hellwig. Madrid: Ediciones Istmo, 1999.

${ }^{102}$ WILKINSON-ZERNER, C. Op. cit., p.35.

${ }^{103}$ PARKER, G. Felipe II. Trad. Ricardo de la Huerta Ozores. Madrid: Alianza Editorial, 2004.
} 
ficou lembrado pela sua capacidade de passar horas e horas incansavelmente lendo papeis para poder tomar as decisões sobre seus reinos, o autor nos coloca: "(...) algunas de las aficiones más arraigadas y profundas de Felipe: las aves, los jardines, la construcción, los ruidos de la naturaleza."104

Para Parker, o principal referencial para as iniciativas do monarca nas reformas ou criações de novos jardins e residências reais se voltava para Flandres. Segundo o autor, as viagens de Felipe II, enquanto ainda era príncipe regente, aos Países Baixos legaram ao futuro monarca uma importante influência em seus gostos. Além disso, através do contato de Parker com os documentos oficiais que se relacionam às atividades cotidianas do rei, o autor nos mostrar todo o controle sobre os funcionários e servidores que estavam envolvidos com arquitetura e jardinagem na península. Buscava árvores, modelos e homens nos Países Baixos, França, Itália e América.

Entre as figuras de destaque no que diz respeito aos servidores do rei estava, nos primeiros anos de seu reinado, o já citado Juan Bautista de Toledo. No entanto, a imagem expressa pelo autor sobre a situação do arquiteto na Espanha é bastante complicada:

"Juan Bautista de Toledo (1500-1567), el principal en los primeiros años, que había trabajado con Miguel Ángel y parecia estar algo ressentido por las pretensioes arquitectónicas del rey, se enfrentaba frecuentemente con su soberano."105

Se Juan Bautista de Toledo nos aparece ressentido pela relação com o rei e os desejos que deveria concretizar para o mesmo, esse conflito aparece como um problema que é solucionado com a escolha dos sucessores de Toledo. Para Parker, não há espaço para os desejos e gostos de nenhum outro homem além de Felipe II no que se refere aos seus locais de descanso e divertimento. O monarca parece convencer o historiador, através dos documentos que estuda, de que sua intenção de controlar tudo e todos em seus reinos fora alcançada, ao menos na arquitetura:

\footnotetext{
${ }^{104}$ Ibidem, p. 59.

${ }^{105}$ Ibidem, p. 66.
} 
"De 1559 en adelante sus arquitectos en El Bosque, en El Pardo y en el Palacio de Madrid recibieron instrucciones detalladas acerca de como construir com ladrillos rojos y pizarra, y se hizo venir un equipo especial de pizarreros flamencos para llevar a cabo los trabajos de techado. Había nacido el 'estilo de Felipe II'."106

Parker trata Herrera e Francisco de Mora, que também atuava para a monarquia como arquiteto, como executores das vontades do rei, muito mais controláveis do que fora Juan Bautista de Toledo. Dessa maneira, mesmo citando suas preocupações com as matérias relacionadas às matemáticas, Herrera aparece como mais um dos inúmeros homens que estavam cooperando para levar a cabo a ideia de Felipe II de como deveria estar organizado e representado o seu governo.

Diferentemente de Parker, René Taylor considera que Herrera realizou contribuição considerável para a formulação da arquitetura que expressaria o reinado de Felipe II. A obra de Taylor, "Arquitectura y Magia. Consideraciones sobre la Idea de El Escorial", pode ser tomada como uma obra clássica, pois se tornou referência para muitos estudos, e ampliou as possibilidades de abordagens e usos da documentação por parte dos historiadores. Apesar disso, já foi muito criticada por parecer contribuir com a "lenda negra" em torno da imagem de Felipe II.

Entre as críticas comentadas pelo próprio autor, nos círculos de seus leitores espanhóis, está o fortalecimento da imagem de um rei supersticioso, juntamente com seu arquiteto. Em sua defesa, o autor coloca que o principal objetivo de sua obra era "demostrar que [Felipe II e Juan de Herrera] eran hombres de su tiempo y en consecuencia abiertos a ciertas ideas de caráter arcano, muy diseminadas en aquela época entre gente de cultura"107

René Taylor publicou o texto originalmente em inglês, em 1967. $\mathrm{Na}$ introdução da edição traduzida para o espanhol de 1992, aponta logo abrindo seu trabalho: "No fue poca la polvarreda levantada en ciertos círculos españoles por el artículo en cuestión." ${ }^{108}$ Hoje contamos com alguns trabalhos já bastante

\footnotetext{
${ }^{106}$ Ibidem, p.65.

107 TAYLOR, R. Arquitectura y magia. Colaboraciones sobre la Idea de El Escorial. Trad. José Luis Oliver Domingo. Madrid: Siruela, 3aㅡ ed., 2000, p.11.

${ }^{108}$ Ibidem, p. 11.
} 
consagrados, que nos são referências para a discussão sobre a memória do hermetismo na Idade Média e no Renascimento.

O historiador italiano Paolo Rossi ${ }^{109}$ deve ser lembrado, ao lado de Francis Yates ${ }^{110}$. As obras desses autores aprofundaram a compreensão da complexidade com que os homens do renascimento lidavam com a questão do saber e da memória. No estudo de Rossi sobre Francis Bacon ${ }^{111}$, o autor apresentanos como um aspecto relevante de fins da Idade Média até o século XVII, a coexistência de um pensamento "racionalista" e um hermetismo, ou mesmo misticismo, entre os pensadores do período. O que hoje poderia soar contraditório, era parte integrante da maneira de entender o mundo desses homens. Eugene Garin também intitula o capítulo dedicado a esses homens de saber, no livro "O homem renascentista", como "O filósofo e o mago", indicando a aproximação que se estabelece entre essas duas figuras que muitas vezes se confundem no Renascimento ${ }^{112}$.

Ainda sobre René Taylor, apesar de abordar um tema que muitas vezes se mostra polêmico, o autor atem-se a documentação para fundamentar todas as suas considerações. Para pensar a importância do Escorial para Felipe II, utiliza o método iconológico ${ }^{113}$, que tem como importante referência Erwin Panofsky ${ }^{114}$. Ao estudar a relação entre arquitetura e magia no Escorial, Taylor continua as

\footnotetext{
${ }^{109}$ ROSSI, P. O passado, a memória, o esquecimento. Seis ensaios da história das ideias. Trad. Nilson Moulin. São Paulo: Editora Unesp, 2007.

${ }^{110}$ YATES, F. A arte da memória. Trad. Flavia Bancher. Campinas: Editora Unicamp, 2007.

${ }^{111}$ ROSSI, P. Francis Bacon. Da magia à ciência. Trad. Aurora Fornoni Bernardini. Londrina: Eduel, 2006.
}

112 GARIN, E. O filósofo e o mago. In: idem (dir.). O Homem Renascentista. Trad. Maria Jorge Vilar de Figueiredo. Lisboa: Editorial Presença, 1991, pp. 121-144.

${ }^{113} \mathrm{GOMEZ,} \mathrm{M.} \mathrm{E.} \mathrm{La} \mathrm{iconología.} \mathrm{Un} \mathrm{método} \mathrm{para} \mathrm{reconocer} \mathrm{la} \mathrm{simbología} \mathrm{oculta} \mathrm{en} \mathrm{las} \mathrm{obras} \mathrm{de}$ arquitectura. In: Argos, 38, julo 2003, pp. 07-39.

114 PANOFSKY, E. Renascimento e Renascimentos na Arte Ocidental. Trad. Fernando Neves. Lisboa, Presença, 1981. 
preocupações iniciadas nas pesquisas de Aby Warburg ${ }^{115}$, que buscava compreender o significado das obras e seus conteúdos como fonte para se compreender a cultura de um período. Erwin Panofsky continua nessa mesma corrente, afirmando que a forma que a obra de arte assume contem em si um significado ou conteúdo intrínseco, que pode ser compreendido através da iconologia.

Segundo Maria Elena Gomez, a iconologia asume:

"la existencia de una parte de la realidade humana que está más allá del mundo material, fáctico y demostrable empíricamente, una realidad que es esencialmente simbólica y requiere de un trabajo de interpretación para ser comprendida."116

Por essa afirmação, podemos compreender as palavras de Taylor na introdução de sua obra. Sua intenção era, através do estudo da arquitetura, identificar as idéias que a geravam e, assim, aprofundar o conhecimento acerca da cultura espanhola da nobreza do século XVI.

O autor começa sua análise discutindo a presença da imagem de um cubo no afresco realizado no Escorial, por Luca Cambiaso, para a abóboda do coro, iniciada por volta de 1584. O tema dessa pintura, "A Glória", representa em destaque a Santíssima Trindade, com Deus Pai e Jesus Cristo, que estão sentados em um arco-íris, e abaixo de seus pés encontra-se um cubo. Se esse elemento aparece na decoração do Escorial era porque o rei aprovou sua introdução, ou mesmo foi o responsável por sua escolha como parte desse afresco, já que Felipe II havia dirigido todo o programa decorativo ali realizado, segundo a argumentação do autor.

\footnotetext{
${ }^{115}$ O método de Aby Warburg e a influência que teve sobre outros historiadores da arte posteriores, entre eles Panofsky, são estudados no artigo de Carlo Ginzburg:

GUINZBURG, C. De Warburg a H. Gombrich: Notas sobre um problema de método. In: idem. Mitos, emblemas, sinais: morfología e história. Trad. Frederico Carotti. São Paulo: Cia. das Letras 1989, p. 41-94.

${ }^{116}$ Ibidem, p. 06.
} 


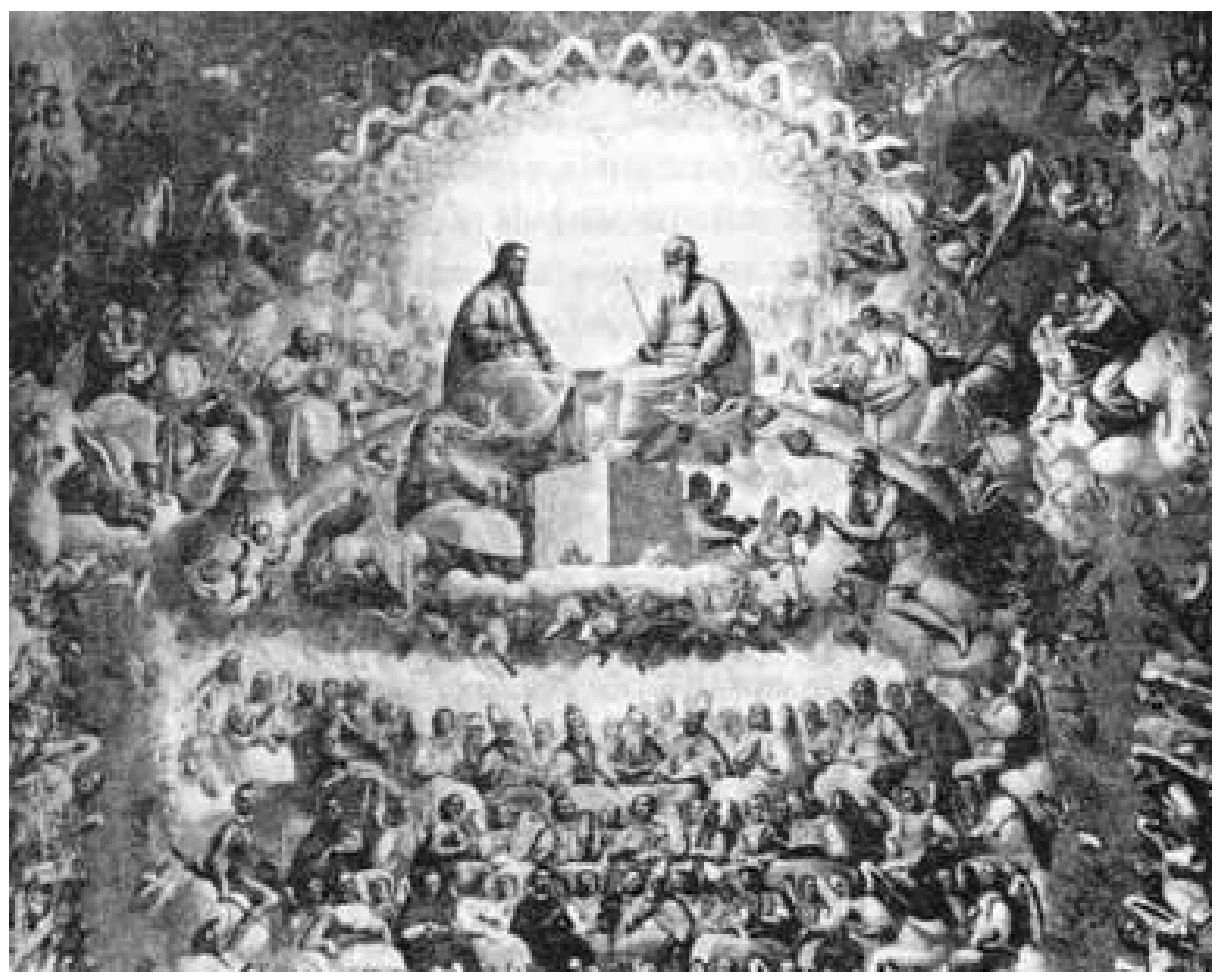

Figura 09 - Detalhe do afresco de Luca Cambiaso da abóboda do coro do Escorial.

Fonte: TAYLOR, R. Op. cit., p.17.

A discussão sobre o cubo segue apresentando a importância dessa figura nas obras de alguns filósofos antigos e humanistas. Entre os que se dedicaram a escrever sobre o cubo estava Juan de Herrera, em sua obra "Discurso sobre la figura cubica"117, que tinha como objetivo apresentar os princípios e a arte de Raimundo Lúlio (c.1229-c.1316) ${ }^{118}$, utilizando-se, em muitos momentos, de

117 HERRERA, J. Discurso sobre la figura cubica [s.d.]. Santander: Biblioteca Menendez Pelayo, [s.d]. Disponível em: http://www.bibliotecademenendezpelayo.org/Visor.aspx?op=6\&Admin=TRUE\&IdLibro=1\&codigo=M72 . Acesso em 22 de novembro de 2006.

${ }^{118}$ Raimundo Lúlio (Ramón Llull) foi um importante pensador do século XIII. Foi cortesão no reino de Maiorca, que acabara de ser conquistado dos árabes. Viveu em período ainda conturbado, de cruzadas e de investidas dos cristãos contra os muçulmanos na Península lbérica. Supostamente, Lúlio teria recebido uma visão de Cristo, por volta de 1265, que o sensibilizara profundamente, a ponto de, a partir desse momento, começar a se inclinar a vida religiosa, o que estaria expresso em seus escritos. Suas obras buscavam criar um sistema para a compreensão de todas as coisas, e também se ocupava da conversão dos muçulmanos. Seu pensamento ainda exercia influência sobre alguns pensadores durante o renascimento, como Juan de Herrera. Há hoje centros de estudos filosóficos voltados a compreender e recuperar sua obra.

ROSSI, P. A chave universal: artes da memorização e lógica combinatória desde Lúlio até Leibniz. Trad. A. Angonese. Bauru: Edusc, 2004. 
definições da matemática euclidiana como "tradutoras", ou seja, como uma linguagem que facilitaria a compreensão de um conhecimento tão elevado quanto este.

Raimundo Lúlio foi um importante escritor medieval de Maiorca, profundamente cristão e comprometido com a conversão dos muçulmanos, que tinha desenvolvido em seus escritos um sistema de pensamento que buscava a compreensão do universo em sua totalidade. Suas idéias ainda tinham adeptos durante o renascimento, entre eles, o próprio Herrera.

A presença do cubo no afresco do Escorial, para Taylor, seria o indício da adesão de Felipe II às idéias de Raimundo Lúlio, o que se deveria à influência de Juan de Herrera. A proximidade entre rei e arquiteto se apresenta entre as justificativas para que este pudesse introduzir Felipe II ao pensamento de Lúlio. Para Taylor, também, não havia contradição entre a postura do rei em realizar um edifício como símbolo de seu vínculo com a lgreja de Roma, seu interesse pelas discussões "científicas" do renascimento e seu conhecimento da arte de Raimundo Lúlio, que tinha um caráter místico. Como o autor aponta, muitos dos que consideramos os primeiros cientistas modernos se dedicavam igualmente às "ciências" e aos temas relacionados à magia e ao hermetismo.

Taylor também levanta a hipótese de que o pensamento de Herrera tenha sido influenciado pelas idéias de Hermes Trimegistro e Lúlio, sobretudo pela presença de obras atribuídas a ambos em sua biblioteca. Seu interesse por astronomia se inicia cedo, quando faz a ilustração o "Libro de Armellas", que mencionamos anteriormente. Esses indícios levam Taylor a considerar que Herrera tinha conhecimentos sobre ocultismo e que, devido à proximidade com o rei, que Felipe II não apenas procurava os serviços de Herrera pelas suas habilidades na arquitetura e matemática, mas por ser versado nas ciências ocultas. Segundo Taylor:

"Herrera se interesso profundamente por este género de estúdios y prestaba al rey ciertos servicios relacionados com ellos, es de suponer qu estarían orientados principalmente hacia la astrologia y la 
medicina, al igual que casi todos los demás soberanos europeus de la época"119

No entanto, há poucas referências às atividades de Herrera como mago. Tal ausência é considerada pelo autor como uma "conspiração de silêncio". Segundo Taylor, há algumas referências sobre o assunto no arquivo toledano do Santo Ofício, mas por motivos de disputas e invejas pessoais essa faceta do arquiteto teria sido menos comentada. Até mesmo o hábito de Felipe II se vestir de preto poderia ser entendido como influência da astrologia, para favorecer a influência de Saturno, o planeta "intelectual", na vida do monarca, diferentemente da interpretação mais comum, que atribui às suas vestimentas a imagem de sua atitude de austeridade e comedimento.

Além de dar grande ênfase à atuação de Herrera, René Taylor busca compreender a relação entre o Escorial e o Templo de Salomão, posteriormente ressaltada por Juan Bautista de Villalpando (1552-1608), que fora discípulo de Juan de Herrera antes de se tornar jesuíta. A maneira como constrói sua argumentação mantém o mesmo tom de valorização do papel do arquiteto junto ao rei e no ambiente que cercava o monarca com diversos de seus servidores.

Taylor também eleva a importância do papel de arquiteto ao buscar referência no pensamento do humanista Marsílio Ficino (1433-1499), que coloca a arquitetura como a mais sublime das ciências depois da matemática, pois ao erguer um edifício o arquiteto imita o labor criador de Deus. Para Ficino, aquele que conhece a arte de edificar é o detentor de um grande saber, o que faz com que seja procurado pelos demais em muitos assuntos.

De maneira muito distinta de Taylor, Catherine Wilkinson-Zerner também coloca no centro de sua pesquisa a imagem de Juan de Herrera. Podemos considerá-la a principal pesquisadora que se dedicou a discutir o papel desse arquiteto junto ao rei. Seu livro "Juan de Herrera: arquitecto de Felipe Il"120, é fruto de uma pesquisa sobre como teria se introduzido o estilo renascentista na Espanha.

\footnotetext{
119 TAYLOR, R. Op.cit., p.21.

${ }^{120}$ WILKINSON-ZERNER, C. Juan de Herrera: Architect to Philip II of Spain. London: Yale University Press, 1993.
} 
Para se aproximar de uma resposta para esta questão, toma como peças fundamentais a construção do Escorial e as atividades desempenhadas por Herrera para a coroa. A autora justifica, como um dos motivos para impulsionar esse trabalho, a ausência de estudos que tratassem dessa problemática na década de 1990. Seu aguçado olhar sobre as fontes Ihe rendeu o prêmio Eleanor Tufts da American Society for Hispanic Art Historical Studies.

Dotando sua obra de extremo rigor, Wilkinson aponta, sobretudo, os limites da função desempenhada por Herrera para a coroa. Essa postura da autora é extremamente valiosa para se aprofundar a compreensão de como se inseriam os serviços dos arquitetos reais na Europa da primeira modernidade. A autora, ao buscar as mudanças que estavam se gestando no campo da arquitetura durante as décadas governadas por Felipe II, também as contextualiza. Estava surgindo uma nova visão do lugar dos arquitetos na sociedade, ainda que fosse pouco claro o próprio estatuto de arquiteto de Herrera, por exemplo.

A autora ressalta as particularidades na trajetória de Herrera. Em primeiro lugar, por não ser comum a um nobre buscar reconhecimento régio através da arquitetura. Mais do que um artista que desejava afirmar um dom natural para as artes, Herrera buscou na arquitetura uma carreira que deveria ser aprendida, ele devia "se fazer" arquiteto, como coloca com suas palavras. Afortunadamente, Herrera, como outros artífices, conseguiu se aproximar de um monarca que admirava a arquitetura e sempre buscava adquirir publicações sobre o assunto.

Todo o trabalho de Wilkinson-Zerner parece buscar um balanço sobre a imagem de Herrera, relativizando a participação que teve em muitas obras cuja autoria lhe foram atribuídas por muito tempo, e demonstrando outros aspectos que foram menos ressaltados de sua atuação.

Também, discute a ideia do que se chama de "estilo desornamentado". A autora coloca como marca do estilo de Herrera a ausência da personalidade do arquiteto, o que, segundo ela, era uma exceção no renascimento, por se caracterizar como um distanciamento da individualidade do autor em relação à obra. Para Wilkinson-Zerner, Herrera buscava transmitir em sua arquitetura, sobretudo no Escorial, apenas a imagem da autoridade real: 
"El sello personal de la autoridad real, que todos, desde Siguenza, vieron en El Escorial, se debe, en ultima instancia a la singularidade del edifício de Herrera. La impersonalidad y la distancia son transmitidas por la riqueza de materiales, sencillamente empleados y belamente trabajados, por la restringida y depurada decoración, y por la abstración extrema para arquitectos. Herrera creó los equivalentes arquitectónicos para el estilo de la realeza de Felipe II. Severo comportamento, prudente juicio y simplicidade exceptional para implicar autoridade total sobre uno mismo y sobre los demás fueron los signos externos de la real persona de Felipe II."121

Além de imenso conhecimento da documentação que permite tentar delimitar os campos e o alcance das ações de Juan de Herrera como arquiteto, o trabalho de Wilkinson nos permite perceber como essa atuação se aproximava, ou afastava-se, do contexto de arquitetos de outros monarcas europeus do momento e da própria discussão teórica, sobretudo, dos autores italianos. Ao longo de todo o livro, as experiências de Herrera são pensadas a partir de uma série de ideias que buscavam definir o papel do arquiteto. Para a autora, os escritos sobre o assunto de homens como Alberti, na Itália, e a retomada da obra de Vitrúvio, influenciavam o surgimento da figura do arquiteto na Espanha desse momento, que realizava suas obras como um produto mental, distanciando-se da tradição medieval dos maestros mayores. Assim, ideias e ações andam lado a lado na análise.

Além de Wilkinson-Zerner, o português Domingos Tavares também se dedicou a escrever sobre Juan de Herrera. O autor escreveu uma coleção de monografias com base nos conteúdos das aulas de História da Arquitetura na Faculdade de Arquitetura da Universidade do Porto. Os volumes dedicam-se aos arquitetos do que intitula como o "ciclo clássico da arquitetura europeia", que abrange desde o renascimento florentino até ao final do período neoclássico. Tavares atribui o subtítulo ao volume dedicado a Juan de Herrera "disciplina na arquitectura"122, que já nos mostra em grande medida a visão que tem em relação ao arquiteto de Felipe II.

Desse modo, enfatiza a importância das questões técnicas solucionadas por Herrera nas obras realizadas para a monarquia. O interesse e seus

\footnotetext{
${ }^{121}$ WILKINSON-ZERNER, C. Op. cit., p. 121.

${ }^{122}$ TAVARES, D. Juan de Herrera. Disciplina na arquitectura. Porto: Dafne, 2005.
} 
escritos sobre máquinas usadas na construção do monastério do Escorial e o "discurso sobre la figura cubica", são algumas das fontes ressaltadas para se compreender a importância de seus serviços. O enfoque de Tavares sempre explicita a importância da organização imposta pelo arquiteto nas obras que dirigiu.

Para Tavares, a importância da arquitetura para a monarquia refletia o desejo dos Reis Católicos de criar uma unidade imperial católica. Para tanto, a arquitetura servia como veículo para tornar visíveis seus valores, através da monumentalização. Segundo o autor, as iniciativas dos monarcas eram legitimadas pelos escritos italianos. Nesse contexto, Herrera contribuiu sistematizando o trabalho envolvido nos projetos que permitiram finalizar, ainda durante o reinado de Felipe II, as obras do monastério do Escorial. O monarca teria o grande mérito de conseguir reunir os melhores colaboradores disponíveis para seu governo, e Juan de Herrera estava entre esses nomes, estando próximo à realeza desde o período de juventude do príncipe.

Se considerarmos obras que não tratam especificamente de Juan de Herrera, devemos lembrar que, nos livros dedicados à arquitetura e à arte em geral na Espanha do renascimento, sempre encontraremos referências à sua contribuição. Como exemplo, podemos citar o notável estudo de Fernando Checa Cremades sobre o mecenato de Felipe II, em seu livro "Felipe II mecenas de las artes" ${ }^{123}$. Também vale ressaltar a obra que contou com a colaboração de Checa, juntamente com Víctor Nieto e Alfredo Morales, intitulado "Arquitectura del Renascimento en España" que discute especificamente a arquitetura espanhola do renascimento ${ }^{124}$, bem como a obra "Arquitectura y sociedade en el Siglo de Oro", de Alicia Cámara Muñoz ${ }^{125}$, que faz uma história social da arquitetura desse período. Nessas três obras citadas, Herrera é lembrado, sobretudo, por sua importância nas discussões sobre instrumentos que auxiliam nas construções, por ser um homem versado nas matemáticas e arquitetura do Renascimento, possuidor de uma rica

\footnotetext{
${ }^{123}$ CHECA CREMADES, F. Felipe II: mecenas de las artes. Madrid: Nerea, 1992.

${ }^{124}$ NIETO ALCAIDE, V. M.; MORALES, A. e CHECA, F. Arquitectura del renacimiento en España, 1488-1599. Madrid: Cátedra, 1993.
}

${ }^{125}$ CÁMARA MUÑOZ, A. Arquitectura y Sociedad en el Siglo de Oro. Madrid: Ediciones El Arquero Textos Universitários, 1990. 
biblioteca nesses assuntos. Nas palavras de Checa, Herrera é "um artista intelectual al servicio del poder"126

Outros autores também colocaram em discussão o papel de Herrera, sobretudo em coletâneas de textos sobre algumas das áreas em que o arquiteto atuou ${ }^{127}$. Cada um desses trabalhos traz uma enorme contribuição para se entender melhor o quão complexas eram as relações estabelecidas entre rei, arquiteto, maestros mayores, engenheiros, engenheiros militares, pintores, escultores, religiosos, etc. No entanto, cada uma dessas obras, em geral, parte das diversas questões apontadas por textos mais amplos que buscavam reabilitar a figura de Herrera. Assim, se ganhamos mais elementos para considerar a importância que adquire a arquitetura ao longo dos anos em que atuou para a coroa espanhola, precisamos retomar sempre os autores considerados clássicos para não perdermos uma visão clara sobre seus serviços, ou mesmo repensar o lugar de Herrera junto à monarquia.

Dessa maneira, apresentamos nossa personagem demonstrando a complexidade de sua imagem na historiografia. Tanto na bibliografia consultada, quanto nas fontes às quais tivemos acesso para nossa pesquisa, o que nos chama sempre a atenção é a ligação entre Herrera e o conhecimento técnico relacionado à arquitetura e matemático, em um sentido mais amplo que apenas suas aplicações na edificação.

Sobretudo pensando no testemunho do padre José de Siguenza, que é a principal fonte para se pensar o Escorial, utilizada pelos historiadores que se debruçaram sobre o tema nas últimas décadas, não se pode negligenciar que a valorização do arquiteto feita pelo padre historiador se volta, sobretudo, ao seu

\footnotetext{
${ }^{126}$ CHECA CREMADES, F. Op. cit, p.109.

${ }^{127}$ Duas coletâneas que consultamos para esta pesquisa:
}

ARAMBURU-ZABALA, M. A.(dir.) e GÓMEZ MARTíNEZ, J. Juan de Herrera e su influencia. Actas del simpósio. Camargo, 14/17 julio 1992. Santander: Unversidad de Cantábria/Fundación Obra Pía de Juan de Herrera, 1993.

CERVERA VERA, L. Intervención de Juan de Herrera en Ediciones de Libros. Madrid: Instituto de Valencia de Don Juan, 1996. 
conhecimento matemático e as inovações técnicas que realizou. Como uma obra realizada para guardar a memória sobre a construção do monastério, além de se preocupar em relatar os fatos, também traz uma imagem propositalmente transmitida sobre a importância e as personagens relacionadas a esse edifício.

Assim, colocamos no segundo capítulo a importância das matemáticas e da arquitetura do reinado de Felipe II, e a participação de Herrera nas iniciativas reais. Buscamos, com isso, construir a argumentação de que o arquiteto Juan de Herrera teve papel fundamental num projeto de administração real que aproximasse as partes de seus territórios, apesar das particularidades da configuração de seu poder. Esse projeto leva em consideração as matemáticas, como apontamos nas páginas seguintes, e a imagem da monarquia ligada à religião, como apontaremos no terceiro e último capítulo. 
CAPÍTULO II - ARQUITETURA E MATEMÁTICAS PARA ORDENAR O REINO 


\subsection{A arquitetura como parte do governo}

Para compreender o significado das ações realizadas pela monarquia durante o reinado de Felipe II, precisamos ter em mente a especificidade da configuração política de seus territórios. Como mencionamos na introdução, segundo Elliot, a Monarquia Hispânica deve ser considerada como uma monarquia compósita, formada por territórios muito distintos, incorporados por negociações, heranças, casamentos e conquistas ${ }^{128}$. Também, segundo Fernando Bouza:

"A maior das virtudes da Monarquia Hispânica foi a sua enorme elasticidade para integrar os seus diferenciados componentes, de Portugal ao Franco Condado, de Milão às Dezessete Províncias dos Países Baixos, e só pode explicar que uma estrutura politerritorial e plurijurisdicional dilatadíssima e inconexa sobrevivesse até aos alvores do século XVIII."129

O resultado dessa união era um governo que compreendia inúmeros reinos, respeitando as diferenças jurisdicionais dos distintos domínios que reconheciam o rei Católico como seu legítimo senhor. Esse respeito significava a preservação das leis, foros, direitos próprios, usos e costumes dos reinos incorporados pela negociação, herança ou conquista, assim como a manutenção das instituições de cada território. Essa formação política não era incomum no século $\mathrm{XVI}$, pois os casamentos entre as famílias reais europeias acabavam unindo reinos sem que suas possessões se fundissem.

\footnotetext{
${ }^{128}$ ELLIOT, J. Op. cit., p.39.

${ }^{129}$ BOUZA ÁLVARES, F. Introdução. In: idem (organização, introdução e notas). Carta para duas infantas meninas. Portugal na Correspondência de Filipe I para suas Filhas (1581-1583). Lisboa: Dom Quixote; Comissão Nacional para as comemorações dos Descobrimentos Portugueses,1998, p.18.
} 


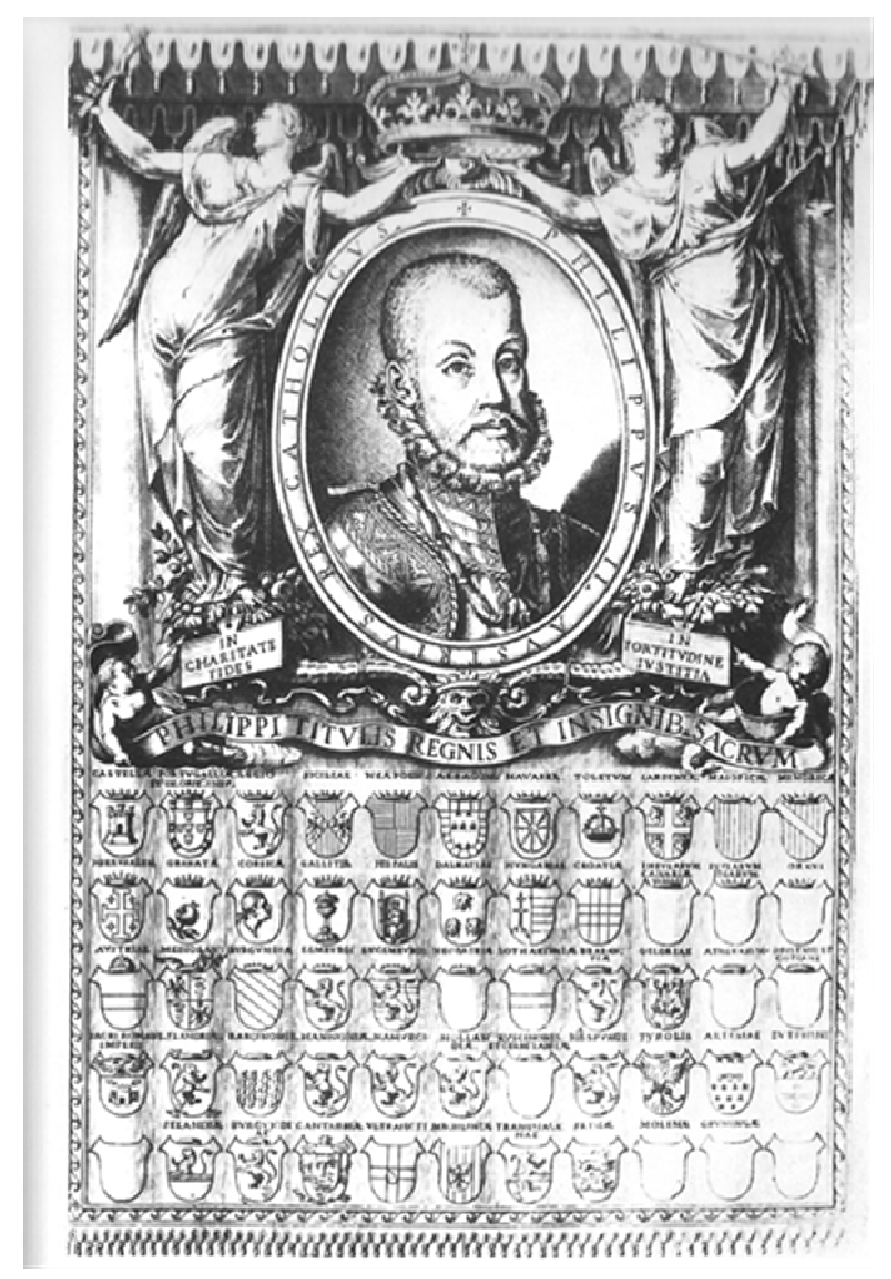

Figura 10 - Gravura de Agostino Caraci - Escudo de Armas de Felipe II.

Fonte: OLLERO, J. Los Austrias. Grabados de la Biblioteca Nacional. Madrid: Biblioteca Nacional, 1993.

No Escudo de Armas de Felipe II (Figura 07), podemos perceber um pouco da complexidade do poder do monarca. A imagem representa o rei em destaque, a faixa com os dizeres "PHILIPPI TITVLIS ET INSIGNIB.SACRVM" e, na parte inferior, os escudos de armas que identificam seus domínios. O primeiro escudo representa Castela, ao lado de Portugal, Leão, Sicília, Nápoles, Aragão, Navarra, Toledo, Sardenha e Mallorca, respectivamente na primeira linha (de cima para baixo), da esquerda para a direita. Nos escudos que podem ser identificados (os que têm a identificação legível), temos representados também, Granada, Córsega, Galícia, Dalmácia, Hungria, Croácia, Ilhas Canárias, Áustria, Burgúndia, 
Luxemburgo, Lotaríngia, Brabante, Sacro Império Romano, Flandres, Holanda, Tirol, Cantábria e Molina ${ }^{130}$.

Essa união de reinos na Espanha já se processava com o casamento dos reis católicos Fernando e Isabel, em 1469. Desde o século XV até finais do século XVI, pouco a pouco, todos os reinos da Península Ibérica passaram a ser governados pelos mesmos reis, sendo que a incorporação de Portugal a essa complexa trama política, de 1580 até 1640 , marca a formação do chamado período de União das Coroas Ibéricas. Com a morte de Dom Sebastião (1544-1578), sucedido por seu tio, o Cardeal Dom Henrique (1512-1580), já idoso e sem filhos, abriu-se espaço para a aproximação de Felipe II em relação à nobreza portuguesa, o que depois Ihe garantiria a sucessão ao trono e a união com o reino vizinho ${ }^{131}$. Segundo Elliot:

"Según el tradicional estilos de los Habsburgo, esta unión de coronas
en 1580 fue otra unión dinástica aeque principaliter, cuidadosamente
concebida para garantizar la supervivencia de la identidad diferente
de Portugal,a sí como la de su imperio. La única medida
específicamente integradora fue la abolición de puestos aduaneros
entre los dos reinos, un intento de unión arancelaria que fue
abandonado en 1592." u32

No caso dessa união com Portugal, Felipe II considerava que, como parte do respeito que deveria ter com o novo reino, o cerimonial português deveria ser mantido em sua visita ao novo território. As festas realizadas para se

${ }^{130}$ Consegue-se ler ampliando a imagem: Castella, Portvgallia et in.orie.insv.; Legio. Siciliae, Neapolis, Arragone, Navarre, Toletvm, Sardinia, Maiorica, Minorica, Hiervsalt (pode haver erro na transcrição porque está pouco legível), Granate, Corsega, Gallitiae, Hispalis, Dalmatiae, hvngarie, Croatiae, Insularvm canarie, Isvlaervm Idiarvm, Orani, Avstriae, Mediolani, Bvrgundia, Lembvrge, Lvcemburge, Neobatriae, Lotharingia, Brabantia, Geldriae, Athenarvm, Oristani et Gotiane, Sacr Romani Imperii, Flandres, Barcinomis, Hannonim, Namverci, Hollandia, Rvscinomis el cerbetania Hiervsalt (pode haver erro na transcrição porque está pouco legível), Hespvrgi, Tyrolis, Artesiae, Zytphini, Selandia, Burgundiae, Cantabria, Molina.

${ }^{131}$ BOUZA, F. Introdução. In: idem (org., intr., notas). Carta para duas infantas meninas. Portugal na correspondência de D. Felipe I para suas filhas (1581-1583). Trad. Nuno Senos. Lisboa: Dom Quixote; Comissão Nacional para as comemorações dos Descobrimentos Portugueses, 1998.

${ }^{132}$ Elliot, J. Op. cit., p.43.

Segundo Elliot, a denominação de união aeque principaliter, significa que reinos continuam sendo tratados como unidades distintas após a união, conservando leis, foros, direitos próprios.

ELLIOT, J. Op. cit., p.43. 
receber Felipe II e Felipe III em Portugal (respectivamente, Felipe I e Felipe II de Portugal) foram estudadas por Ana Paula Torres Megiani ${ }^{133}$, o que revela-nos, sobretudo no que diz respeito ao primeiro monarca do período de União das Coroas Ibéricas, como rei e súditos comunicavam-se nesse momento.

Também, durante os anos em que Felipe II permaneceu em Portugal, de 1581 a 1583, o monarca escreve uma série de cartas às suas filhas, Catarina Micaela e Isabel Clara Eugênia. Nessas cartas, que tinham caráter privado, o rei comenta sobre a necessidade de se manter o cerimonial português e recomenda que seu filho, Dom Diogo, também jurado herdeiro de Portugal nas cortes de Tomar de abril de 1581, deveria aprender a língua portuguesa: "procurai que [também] o entenda seu irmão o que será necessário para que receba os que forem daqui e fazei-o ler português e explicai-Iho, já que tão bem o entendeis"134

Dessa maneira, segundo Bouza Álvares, a imagem que se tinha do rei não era única, pois se apresentava de maneiras distintas aos seus reinos:

"Importa insistir que não existiu uma imagem única da majestade do rei D. Filipe, extensível a toda sua Monarquia, a qual se caracterizava, como já dissemos, pelo reconhecimento da pluralidade jurisdicional dos diferentes domínios que a integravam. Por isso era preciso que se apresentasse de forma distinta como rei próprio de Portugal, como senhor de Milão, como duque de Brabante ou como rei de Nápoles, adoptando em cada caso as regalias ou emblemas do poder próprios de cada domínio. Assim, a apresentação em majestade de D. Filipe I em Tomar devia conformar-se a uma etiqueta particular que seria a tradicional, seguida nas cerimónias da Casa de Avis." ${ }^{.135}$

Apesar de se observar essa preocupação em garantir aos reinos esse caráter de diferenciação dentro da Monarquia Hispânica, o reinado de Felipe II também apresenta tentativas de concentração de algumas iniciativas de governo

\footnotetext{
${ }^{133}$ MEGIANI, A.P.T. O rei ausente. Festas e Cultura Política nas visitas dos Felipes a Portugal (15811619). São Paulo: Alameda, 2004.

${ }^{134}$ Carta escrita em Lisboa, a 01 de outubro de 1582:
}

BOUZA ÁLVARES, F. J. (org., introd. e notas). Cartas para duas infantas meninas: Portugal na Correspondência de Filipe I para suas Filhas (1581-1583). Lisboa: Dom Quixote; Comissão Nacional para as comemorações dos Descobrimentos Portugueses, 1998, p.167.

${ }^{135}$ Ibidem, p.22. 
sob a alçada real. Nesse sentido, identificamos alguns aspectos em que o rei cria projetos que se estendessem aos seus reinos ibéricos, em termos gerais. Tais projetos, como a Academia de Matemáticas, que trataremos na segunda parte desse capítulo, demonstram a capacidade de apropriação de iniciativas anteriores dos reinos que passavam a compor a sua monarquia. Uma das vantagens em ser senhor de tantos reinos era conhecer a arquitetura desses locais, seus humanistas, arquitetos, as plantas, os animais, que poderiam ser incorporadas em seus jardins, seus palácios, igrejas, etc.

Colocamos também, nesse mesmo sentido de aproximação entre seus domínios, a criação de um estilo em suas edificações, que se repetiam nas cidades, como uma maneira do poder real se mostrar presente nesses locais. Também o estilo régio em palácios e monastérios (que nem sempre estavam completamente inseridos em uma malha urbana existente), como modelo que seria tomado e seguido, por arquitetos e maestros mayores, em obras que não tinham relação direta com a monarquia, pode ser considerado um elemento "unificador". Exemplo disso seria o caso apresentado da Catedral de Valladolid, realizada por Herrera, e que trazia em suas soluções para o edifício discussões iniciadas na construção do Escorial.

Dessa maneira, colocamos em primeiro lugar algumas considerações sobre a concepção de Felipe II e Juan de Herrera sobre arquitetura. Em seguida, apontamos como o monarca realiza a arquitetura nas cidades e como cria maneiras de gerenciar os edifícios existentes e os que seriam realizados, através de leis, como "Las Ordenanzas...", e de órgãos ligados à burocracia real, como a "Junta de Obras y Bosques". Por fim, abordamos sua preocupação com os palácios e a recepção de suas iniciativas arquitetônicas, sobretudo por estrangeiros. Essas considerações nos apontam a importância da arquitetura como parte do governo nesse momento.

O interesse de Felipe II por arquitetura remonta aos seus primeiros estudos com Juan Calvete de la Estrella (c.1510-1593) ${ }^{136}$. Quando o

\footnotetext{
${ }^{136}$ Juan Calvete de Estrela foi um dos responsáveis pela educação de Felipe II, junto com Honorato Juan, Juan Ginés de Sepúlveda e Francisco de Vargas. Escreveu várias obras, entre elas um relato da viagem do príncipe Felipe aos Países Baixos ("El felicisimo viaje del muy alto y muy poderoso
} 
príncipe tinha quinze anos, em 1541, seu preceptor comprou do livreiro Juan Medina o "Tratado Medidas del Romano", de Diego de Sagredo ${ }^{137}$. No mesmo ano, passam a fazer parte da biblioteca de Felipe II vários exemplares de Vitrúvio e um de Sebastiano Sérlio ${ }^{138}$, um livro de Euclides (c. 330 a. C. -260 a.C.) ${ }^{139}$ e um de figuras de arquitetura ${ }^{140}$. No ano seguinte, Cavete de Estrella também encomendou para o príncipe o livro "Geometria y Arquitetura", de Albrecht Dürer, além das obras de Erasmos: "Adagios”, "Querela pacis” y "Elogio da Loucura”. Também adquiriu obras de Pedro Apiano ${ }^{141}$, além de Ptolomeu, Copérnico, Arquimedes, etc., quando tinha

principe don Phel ippe" - 1552), fez uma célebre descrição do monumento funerário em memória do Imperador em San Benito de Valladolid ("El tvmvlo imperial ..." - 1559), entre outras obras, inclusive como cronista colonial.

CALVETE DE ESTRELLA, J. C. El felicisimo viaje del muy alto y muy poderoso principe don Phel ippe (Felicíssimo viaje de Felipe ii). Madrid: Museo del Prado, 2001.

NIETO ALCAIDE, V. M.; MORALES, A. e CHECA, F. Op. cit., p.253.

${ }^{137}$ A obra de Diego de Sagredo foi de extrema importância para que arquitetos e patronos da arquitetura na Espanha se aproximassem das ideias discutidas na Itália. Segundo Alicia Cámara Muñoz:

"Cuando Diego de Sagredo escrebió sus "Medidas del romano" (Toledo, 1527) dejó en letra impresa, por primera vez en nuetro ambiente artístico, diferenciado al arquitecto de la figura del maestro de obras cuyas manos eran solo la herramientas de la que se servía el arquitecto. Este debía saber aquello queVitruvio había dejado estabelecido: 'philosophía y artes liberales' y, sobre todo geometria."

CAMARA MUÑOZ, A. Op. cit., 45.

${ }^{138}$ O tratado de Sebastiano Serlio "I sette libri dell'architettura", foi traduzido para o castelhano em 1552, por Villalpando (apenas livros III e IV).

Ibidem, p. 45.

139 Os treze livros que compõe "Os Elementos da Geometria" de Euclides foram tomados no Renascimento como base para se estudar geometria.

GARIN, E. Ciência e vida civil no renascimento italiano. São Paulo: Editora Unesp, 1996.

${ }^{140}$ NIETO ALCAIDE, V. M.; MORALES, A. e CHECA, F. Op. cit., pp.253-254.

${ }^{141}$ APIANO, P. (1495-1551). Libro de la Cosmographía de Pedro Apiano, el qual trata de la descripción del Mundo, y sus partes, por muy claro y lindo artificio, augmentado por el doctíssimo Gemma Frisio... con otros dos libros del dicho Gemma, de la materia misma. En Enveres : En casa de Gregorio Bontio, 1548

Exemplar do Real Instituto y Observatorio de la Armada (San Fernando), Copia digital. Madrid: Ministerio de Cultura. Subdirección General de Coordinación Bibliotecaria, 2008. Disponível em: http://bvpb.mcu.es/museos/es/consulta/registro.cmd?id=399497 
cerca de dezoito anos. ${ }^{142}$ Em 1547 há novas aquisições de livros: Monterreggio, "La Esfera" de Sarcobosco e a obra do matemático Orontio Fineo francês (Oronce Finé), "De quadratura, Sphera y Aritmetica". ${ }^{143}$

A presença desses livros na biblioteca de Felipe II, além de seu caráter colecionista (já que havia muitas edições de uma mesma obra) ${ }^{144}$, também demonstra a preocupação de seus preceptores, e do próprio príncipe, nos assuntos relacionados às matemáticas e à arquitetura. Segundo Alícia Cámara Muñoz, a imprensa e as traduções de tratados de arquitetura influenciavam muito nos gostos dos patronos e na formação dos arquitetos ${ }^{145}$, dessa forma, as novas obras publicadas na Itália e Espanha também aparecem influenciando o gosto de Felipe II, o que levou, muitas vezes a se considerar que Felipe II era um entendido na arquitetura ao ponto de exercer enorme controle de seus arquitetos através de seus conhecimentos ${ }^{146}$.

Além disso, o que o humanismo considerava útil ao conhecimento de todos os homens, como as matemáticas e os temas de filosofia dos antigos, era também o que se colocava nos tratados como base do saber arquitetônico. ${ }^{147}$ Para ter-se ideia, Juan de Herrera possuía em sua biblioteca livros de Vitrúvio ("De Architectura Libri Decem" - sec. I a.C), Leon Batista Alberti ("De re aedificatoria" - 1452), Sebastiano Serlio ("I sete libri de architecttura" - 1570), Giacomo Vignola ("Regola delli cinque ordini di

\footnotetext{
${ }^{142}$ SÁNCHEZ RON, J. M. La ciencia en el Monasterio del Esocrial. In: JAVIER CAMPOS, Francisco e SEVILLA, Fernández de. Actas Del Simposium. Escorial: Real Centro Universitario Escorial-María Cristina, pp.39-72.
}

${ }^{143}$ As fontes sobre as compras de livros para Felipe II encontram-se em: Arquivo General de Simancas, CSR 36, fólio 1; fólios 220v-224, ordem de 20 de janeiro de 1547. Apud: PARKER, G. Op.cit., p.254.

\footnotetext{
${ }^{144}$ MEGIANI, A.P.T. Memória e conhecimento do mundo: coleções de objetos, impressos e manuscritos nas livrarias de Portugal e Espanha. In: Anais do Museu Paulista. São Paulo, v.17. n.1, jan.- jun. 2009, p. 155-171.

${ }^{145}$ CAMARA MUÑOZ, A. Op. cit., p. 60.

${ }^{146}$ PARKER, G. Op. cit.

LOEWEN, A. B. Estilo desornamentado, arquitetura-chã: alguns aspectos do Renascimento na Península Ibérica. In: Revista do Programa de Pós-Graduação em Arquitetura e Urbanismo/FAUUSP. São Paulo, vol.18, n. 30, dez. 2011, pp.56-69.

${ }^{147}$ CÁMARA MUÑOZ, A. Op. cit., p. 57.
} 
architettura" - 1562), Diego de Sagredo ("Medidas del Romano" - 1527), tratados de Philibert de I'Orme (1567- "Les livres de architecture") e de Rusconi ("Dell'architettura di Gio Antonio Rusconi" - 1590), além de muitos livros de astrologia, fortificação, aritmética, geometria, artilharia ${ }^{148}$, tudo o que era necessário para a sua formação como um arquiteto intelectual, bem como de um humanista.

Além da atenção que o rei dedicava à arquitetura, os arquitetos espanhóis, nos séculos XVI e XVII, tinham cada vez mais contato com livros de arquitetos e humanistas italianos e de outros lugares da Europa (Dürer, dos Países Baixos, e o francês Philibert de l'Orme, por exemplo). Alicia Cámara Muñoz identifica que eram frequentes, nas bibliotecas dos arquitetos que realizavam serviços à monarquia, as obras de Vitrúvio, Alberti, Serlio (mais frequentemente as traduções para o castelhano dos livros III e IV realizadas por Villalpando em 1552) e Vignola. A autora coloca que as bibliotecas dos arquitetos espanhóis revelam que estes eram atentos ao que se publicava sobre sua arte, e que transmitiam esses conhecimentos teóricos aos seus discípulos. Também aponta que, devido à valorização da teoria para a afirmação dos arquitetos expressa nos tratados, que eram lidos por príncipes educados por humanistas, como fora Felipe II, e pelo custo em se adquirir obras impressas, "Los libros en esta época fueran un medio de ascenso social para una elite 'tecnica' de professionales, que quanto más cultos fueran mejor estarian considerados social y economicamente."149

Outro fator importante para a formação do gosto de Felipe II, no que diz respeito à arquitetura, está relacionado às suas viagens e as notícias que teve sobre as obras realizadas em outros reinos. Entre 1548 e 1551, ainda enquanto

\footnotetext{
${ }^{148}$ Alicia Cámara Muñoz cita esses autores como parte da biblioteca de Juan de Herrera, mas sem mais especificações.

CÁMARA MUÑOZ, A. Op. cit., p. 57

Catherine Wilkinson-Zerner menciona o inventário dos livros de Juan de Herrera realizado por Cervera Vera:

CERVERA VERA, L. Inventario de los bienes de Juan de Herrera. Valencia: Albatros Ediciones, 1977. Apud. WILKINSON-ZERNER, C. Op. cit.

${ }^{149}$ CAMARA MUÑOZ, A. Op. cit., p. 62.
} 
príncipe regente, Felipe viajou com um séquito de nobres à Italia e aos Paises Baixos, onde conheceu inúmeros edifícios renascentistas, especialmente em Bruxelas, e ao passar pelas cidades de Mântua, Milão e Gênova. Entre 1554 e 1559, passou muito tempo na Inglaterra, onde era rei consorte, devido ao seu matrimonio com Maria Tudor (1516-1558), mas também se dirigia muitas vezes de lá aos Países Baixos ${ }^{150}$. Após a morte de Maria Tudor, Felipe fixa-se na Espanha e se torna um rei bastante sedentário, permanecendo muito tempo nesse território.

Dessas viagens vieram as referências, que muitas vezes são identificadas pelos autores ${ }^{151}$, sobre os gostos dos jardins inspirados na região da Flandres, os telhados, a arquitetura clássica de inspiração italiana, etc. Além das viagens do rei, muitos arquitetos também procuravam dirigir-se à Itália para conhecer suas ruínas antigas e ver as edificações mais recentes, de Leonardo, Michelângelo, Brunelleschi etc ${ }^{152}$. Devemos lembrar que o próprio Juan Bautista de Toledo viveu na Itália onde atuou com Michelângelo. Também Juan de Herrera esteve com o rei nas viagens para a Itália de 1548, onde conheceu as obras renascentistas, e para Portugal, onde ajudou nos preparativos das entradas régias de 1581, tomando conhecimento de algumas iniciativas arquitetônicas desse reino.

Além dos livros adquiridos e que circulavam na Espanha entre os agentes envolvidos nas iniciativas arquitetônicas do momento, e das viagens (que davam conhecimento dos edifícios efetivamente realizados a partir das ideias desses tratados), são fundamentais, para se compreender a concepção sobre a arte de

\footnotetext{
${ }^{150}$ PARKER, G. Op. cit.

${ }^{151}$ WILKINSON-ZERNER, Op. cit.

PARKER, G. Op. cit.

CAMARA MUÑOZ, A. Op. cit.

NIETO ALCAIDE, V. M.; MORALES, A. e CHECA, F. Op. cit.

MARÍAS, F. Op. cit.

${ }^{152}$ CAMARA MUÑOZ, A. Op. cit., p. 65.
} 
edificar desse momento, as concepções expressas em um tratado anônimo que foi escrito na corte de Felipe enquanto príncipe regente ${ }^{153}$.

Esse tratado foi estudado por Catherine Zerner-Wilkinson e Fernando Marías ${ }^{154}$, que consideram que deveria se destinar ao uso particular de Felipe II, pois seu autor deixa claro que o príncipe tinha Ihe solicitado pessoalmente o tratado, e por se tratar de um manuscrito. Seu conteúdo tem o sentido de informe, baseando-se principalmente em Alberti e Vitrúvio. $O$ tratado se concentra no aspecto moral da arquitetura, cuja ideia se expressava sucintamente em Alberti, e que é desdobrada pelo autor, influenciado, sobretudo, pela Contra-Reforma.

Segundo esse autor, para que fosse possível introduzir o estilo albertiano da arquitetura na Espanha, como desejava Felipe II, era necessário atender a dois requisitos. Em primeiro lugar, os "arquitectos" deveriam se diferenciar dos "obreros", sendo que o conhecimento do arquiteto deveria vir do estudo e não da prática, como se formavam os construtores. Em segundo lugar, também deveria surgir o cliente adequado, que ainda não existia na Espanha e, nesse quesito, o rei era o sujeito privilegiado para iniciar essa prática. Por fim, o texto apresenta um programa de reformas para a arquitetura espanhola, que resultaria na construção de um novo estilo que personificasse as virtudes da Monarquia Hispânica.

Essa aproximação entre a arquitetura e a personificação daquele que a patrocina, também está presente nas concepções humanistas sobre as

${ }^{153}$ El tratado anônimo de arquitectura dedicado a Felipe III - Biblioteca Nacional de Madrid, manuscrito 9681.

Inicialmente, considerava-se que esse tratado havia sido escrito para Felipe III, mas a partir dos estudos de Wilkinson-Zerner e Fernando Marías, com a análise desse documento e considerando o contexto da corte de Felipe III, consideraram que é mais provável que esse documento se destinasse a Felipe II:

MARIAS, F. Um tratado inédito de arquitectura de hacia 1550. In: Boletin del Museo e Instituto Camón Aznar, XIII, 1983, pp.91-57.

WILKINSON-ZERNER, C. Planning a Style for the Escorial: An architectural treatise for Philip of Spain. in: The Journal of the Society of Architectural Historians, vol. 44, No. 1 (mar. 1985), pp. 37-47.

${ }^{154}$ Ibidem. 
cidades ideiais, nas quais há uma ligação estreita entre o papel do cidadão e os edifícios que utiliza, e a valorização dos antigos a partir de suas obras, relacionando suas qualidades às qualidades de suas construções, o que também pode ser observado nas palavras de Siguenza que apontamos anteriormente.

Um exemplo dessa concepção é a ideia de ruínas do império romano, que pode ser bem observada nas palavras de Rafael de Sanzio ao papa Leão X. Neste documento, provavelmente escrito em colaboração com Baltasar Castiglione, na primeira metade do século XVI, o autor colocava como prova irrefutável da grandeza do conhecimento dos antigos, a visão das ruínas deixadas em Roma: "perchè considerando dalle reliquie che ancor si veggono delle ruine di Roma la divinità di quegli animi antichi, non istimo fuor di ragione II credere che molte cose a noi paiano imposibili, che ad essi erano facilissime." ${ }^{155}$ Nas palavras de Rafael aparece a expressão "divinas almas antigas", sugerindo que as qualidades expressas na arquitetura iriam muito além das capacidades de construção de edifícios.

No texto de Eugenio Garin, "A cidade ideal"156, o autor nos apresenta essa relação entre edifício e aqueles que o mandam edificar ou que habitariam em suas dependências. Sua análise se dá a partir da cidade ideal desenhada por Leonardo da Vinci. A preocupação com a salubridade aparecia nos desenhos de Da Vinci, mas seus edifícios deviam também conter elementos que os colocassem como personificação da república (já que a referência de modelo político ideal para o autor era a das cidades italianas). Os espaços a serem utilizados por

\footnotetext{
155 "considerando as relíquias que ainda vemos das ruínas de Roma, a divindade daquelas almas antigas, opino não estar além da razão acreditar que muitas coisas que para nós parecem impossíveis, para eles eram facílimas"
}

DI TEODORO, F. P. Rafael, Baldessar Castiglione e la lettere a Leone $\mathbf{X}$ sulle rovine di Roma. Bologna: Nuova Alfa, 1996, p.146.

Tradução para o português retirada da dissertação de mestrado:

SOUSA, M. L. Z. de. Carta de Rafael Sanzio - Catilione ao Papa Leão X e sua importância para o estudo da arquitetura e urbanismo do período do Renascimento (Dissertação de mestrado). São Paulo: Faculdade de Arquitetura e Urbanismo da Universidade de São Paulo, 2006, pp.115.

${ }^{156}$ GARIN, E. A cidade ideal. In: idem. Ciência e Vida Civil no Renascimento. São Paulo: Editora UNESP, 1996, p.53-80. 
gentis-homens e pela população comum são facilmente distinguíveis. Nas palavras de Garin: "a cidade deve ser construída na medida do homem, no exercício de sua mais elevada atividade, o "gentil homem", vive na luz e na harmonia, os edifícios, as ruas, os lugares deverão adequar-se a essa natureza."

Não apenas Leonardo da Vinci tratou do tema da cidade em seus escritos. Os textos que abordam esse assunto revelam-nos uma importante discussão que se mostrava muito presente aos monarcas do século XVI. Os projetos desses centros urbanos ideais pretendiam reorganizar a vida de seus habitantes, a partir de uma intervenção que transfigurasse as feições medievais desses espaços para os moldes renascentistas. Devido aos custos de se erguer uma cidade inteira, ou mesmo de se fazer uma reforma com transformações profundas, percebemos que tais textos não tinham como intenção transformar completamente os centros urbanos europeus. Sua principal contribuição estava em expor a visão que se desejava difundir sobre o ordenamento das pessoas e lugares ali existentes, servir de parâmetro para novas intervenções e, sobretudo, difundir o ideal humanista de cidadão.

Por exemplo, em "De re aedificatoria", de Leon Battista Alberti (1452), a ideia de cidade exposta delimita bairros diferentes para os grupos sociais ali existentes, as ruas são reservadas para determinados ofícios e são previstos asilos para os pobres. Assim, havia um modelo de vida em cidade, de organização segundo os ideais humanistas. Antonio Avelino, o Filarete (1400-1466), também tratou desse tema, desenhando uma cidade fantástica em seu "Trattato". Não coincidentemente, a cidade se chamava "Sforzinda", em alusão à família Sforza, para a qual Filarete realizava muitos serviços. ${ }^{158}$

Dessa forma, as preocupações de Felipe II, inseridas nesse contexto, colocavam na arquitetura o peso de expressar a imagem do rei. No que diz respeito às cidades, também se voltava para marcar a presença dos espaços reais nos centros urbanos. Essas iniciativas tinham um peso político importante, devido à

\footnotetext{
${ }^{157}$ Ibidem, p.59.

${ }^{158}$ ORNELAS BERRIEL, C. E. Cidades utópicas do renascimento. In: Revista Ciência e Cultura. vol.56, no.2, São Paulo apr./june 2004, pp.46-48.
} 
resistência e contestação realizada pelas cidades em relação à monarquia desde a revolta dos comuneros ${ }^{159}$.

A revolta dos comuneros (1521) demonstra, em grande medida, a fragilidade da construção de uma monarquia hispânica a partir do casamento dos Reis Católicos. Quando Carlos I, pai de Felipe II, tornou-se rei de Castela, algumas cidades se revoltam contra sua autoridade, reagindo às decisões que o monarca tomava. Desse episódio, percebemos o quanto a relação entre poder monárquico e poder local, das cidades, nem sempre era tranquila e que era uma necessidade do monarca mostrar-se presente nas cidades. A educação de Felipe II e sua ligação com a península são em grande medida consequências dessa revolta, já que uma das queixas dos comuneros se referia ao fato de rei parecer-lhes como um estrangeiro (nascera e fora criado nos Países Baixos). Como Geoffrey Parker ${ }^{160}$ coloca, Felipe II era excessivamente espanhol, diferentemente de seu pai, que se mostrou um rei ausente na península e envolvido em muitas guerras.

No que diz respeito ao ordenamento das cidades, Felipe II criou um conjunto de leis para o Novo Mundo: "Las Ordenanzas de 1573". Esse documento fixava as instruções sobre a criação de novos centros urbanos no continente americano. Para organizar a cidade, seu primeiro edifício e principal elemento era a "Plaza Mayor", uma criação característica espanhola para dar um aspecto ordenado às suas antigas cidades de traçados orgânicos. A "plaza" estava destinada a ser o centro comercial, e as fachadas dos edifícios que a delimitavam manteriam a uniformidade, que não deveria ser quebrada pela presença de monumentos, inclusive. A igreja principal deveria se situar em uma praça completamente independente do centro comercial, em uma posição dominante e visível $^{161}$.

\footnotetext{
${ }^{159}$ MARAVALL, J. A. La oposición política bajo los Austrias. Barcelona: Ariel, 1974.

${ }^{160}$ PARKER, G. Op. cit.

161 VAS MINGO, M. M. Las Ordenanzas de 1573, sus antecedentes y consecuencias. In: Revista Quinto Centenario, Universidad Complutense de Madrid, 1985, Número 8, pp. 83-101.
} 
Segundo Fernando Chueca Gotia, essas leis promulgadas por Felipe II "talvez constituam a primeira legislação urbanística que o mundo conheceu"162, e se baseavam na experiência prática adquirida nos novos territórios americanos e na influência das ideias de Vitrúvio. Segundo o mesmo autor, assim a "planta regular axadrezada fica consagrada nestas leis, o que não faz mais do que consolidar uma realidade."163

No entanto, alguns limites se impunham aos desejos do rei, seja pela distância e pela dificuldade em se supervisionar se tais instruções eram seguidas, ou pelo fato de que, na década em que são escritas, muitas das cidades americanas já tinham sido construídas. Além disso, como aponta Catherine ZernerWilkinson, "Las Ordenanzas promulgaran un ideal humanista de vida social que habría sido difícil llevar a cabo en la práctica en ese tiempo, y representaban a una sociedad mucho más ordenada, virtuosa y pacifica que la que conocía Felipe II."164 Segundo a mesma autora, dada a proximidade de Herrera junto ao rei no momento em que esse documento foi escrito, é possível se pensar em sua participação na gestação das ideias que estão na base da organização urbana das cidades do Novo Mundo.

Percebemos assim que, mesmo no continente americano, onde havia mais espaço para se criar cidades renascentistas, havia muitos limites para essa realização. No que diz respeiro às cidades na Península Ibérica, a questão era ainda mais complicada.

Neste sentido de colocar sua imagem nas cidades, Felipe II dedicou maior atenção à Madrid, que tinha se transformado em sua nova capital ${ }^{165}$,

\footnotetext{
${ }^{162}$ CHUECA GOTIA, F. Breve História do Urbanismo. Lisboa: Presença, 1992, p.120.

${ }^{163}$ Ibdem, p.120.

${ }^{164}$ WILKINSON-ZERNER, C. Op. cit., p.154.

${ }^{165}$ É importante ressaltar que o termo utilizado para tal cidade nesse momento não era "capital". Madrid havia se tornado corte, o que tinha duplo sentido: designava o rei e seu séquito, bem como o local em que era sua sede habitual. No entanto, a permanência dos reis nessa cidade se manter a partir da fixação de Felipe II, e a atenção redobrada que recebe a partir de então (com exceção do período de permanência da corte em Valladolid, de 1600 a 1606) justifica que usemos o termo "capital" para designar a importância e papel desta cidade na Península Ibérica.
} 
substituindo a itinerância característica até então. Madrid se encontra no centro geográfico da Península Ibérica, o que torna sua localização privilegiada para que o rei se deslocasse da capital para quaisquer outras cidades da península. Além disso, como era um pequeno núcleo urbano até então, a inexistência de poderes eclesiásticos que disputassem o protagonismo com o rei nesse cenário também se mostrava como um aspecto favorável a sua elevação. Também possuia considerável área para se ampliar sua malha urbana, com a atração populacional que a nova capital criaria. As obras realizadas neste e em outros centros urbanos aparecem-nos mais por sua considerável importância prática do que por seu apelo monumental e simbólico.

Em Madrid realizaram-se inúmeras obras necessárias para que esta se transformasse na cidade que concentraria a maior parte das funções administrativas da Península Ibérica. Além disso, a cidade também sofreu com 0 crescente fluxo de migrantes devido à atratividade que ganhara por sua nova função política. Cristóbal Perez de Herrera (1558-1620) escreveu, em 1597, para Felipe II, sobre as novas necessidades para aquela capital tão populosa e pedia ao rei que realizasse reformas em Madrid ${ }^{166}$.

No sentido de ordenar a cidade, em 1590, Felipe II dividiu Madrid em distritos que facilitariam a execução das reformas. O monarca pensava tanto na organização urbana, com as vias, quanto no abastecimento de seus habitantes, com obras hidráulicas e estabelecimentos de fornecimento de víveres. Foi criada uma via principal que a cortava desde o Alcázar até o monastério de São Jerônimo. Ao longo

RIO BARREDO, M. J. Madrid, Urbs Regia. La capital cerimonial de la monarquia católica. Madrid: Marcial Pons, 2000, p.06.

166 Cristóbal Perez de Herrera foi um dos mais importantes e conhecidos médicos espanhóis do século XVI. Nasceu em Salamanca, em 1558, em uma família de militares, sendo que também serviu como protomedico das galeras reais. Paralelamente a sua especialidade como médico, desenvolve uma intensa atividade como arbitrista, ou seja, com escritos contendo a identificação de problemas dentro do reino e propostas de soluções para os tais problemas. Nesse sentido, Perez de Herrera escreveu memoriais sobre diversos assuntos, dirigidos aos reis Felipe II e Felipe III. Entre seus escritos destaca-se o "Discurso del Amparo de los legítimos pobres", obra publicada em 1598, em que o autor expunha um programa de beneficência que realizaria com sua iniciativa, se fosse aprovado por Felipe II. Falleció en Madrid en 1620.

CAVAllieR, M. El Madrid "Utópico" (1597-1600) de Cristóbal Perez de Herrera. In: Bulletin Hispanique. Vol 104, n. 104, Bordeaux, 2002, pp. 627-644. 
dessa via se encontravam seus principais espaços cívicos - Puerta del Sol, Puerta de Guadalajara e a Plaza Mayor (que nesse momento ainda não estava construída, mas apenas traçada). Outras importantes ruas foram abertas e convergiam para essa artéria principal. A "Plaza Mayor" contaria com uma peixaria, açougue e padaria, pensando no abastecimento da população. $O$ rei também fundou um hospital geral, mas não deu à cidade uma catedral ou colegiada.

A participação de Herrera nessas reformas, sobretudo no que diz respeito à Plaza Mayor, pode ser identificada devido à criação de uma junta para as obras, da qual o arquiteto do rei fazia parte. O escrivão Francisco Martínez deixounos um informe de 1586, que relata a participação de Juan de Herrera nessas obras:

"Madrid 19 abril de 1586 el sr Juan de Herrera maestro mayor de
obras de su magd e aposentador de palácios e dixo quel a hecho
para esta villa y en su seruicio muchas traças en condiciones ansi
para la puente real nueua que haze en el rrio della como para las
casas de la manzana de sta cruz puerta de Guadalajara planta desta
va y traza de la plaça mayor della y para todo lo demas que se le
oferecido despues que esta en esta a va la corte de Su magd hasta
agora y en todo lo demas que la dha vale a querido ocupar por lo
qual et tenia pretension contra la dha va..."167

$\mathrm{Na}$ imagem 11 podemos ver o plano para representar a cidade de Madrid, "La topografia de la villa de Madrid", realizado pelo português Pedro Teixeira, de $1656^{168}$. Tal plano, segundo María José Rio Barredo, foi a primeira forma gráfica fiel aos contornos reais realizada para essa cidade. É possível identificar algumas ruas de maior extensão, que facilitam a locomoção e ordenam cidade; uma "plaza" quase ao centro, entre outros espaços abertos; e a interligação com os espaços ajardinados no entorno do núcleo urbano ${ }^{169}$.

\footnotetext{
167 Archivo Histórico de Protocolos, Madrid, Francisco Martínez, leg. 421, fólio 269 v. apud. WILKINSON-ZERNER, C. Op. cit., p.205.

168 CAPUZANO, M.M. Planos de Madrid de los siglos XVII e XVII. Madrid: 1970. Apud. WILKINSON-ZERNER, C. Op. cit., p.150.

${ }^{169}$ RIOS BARREDO, M.J. Op. cit.
} 


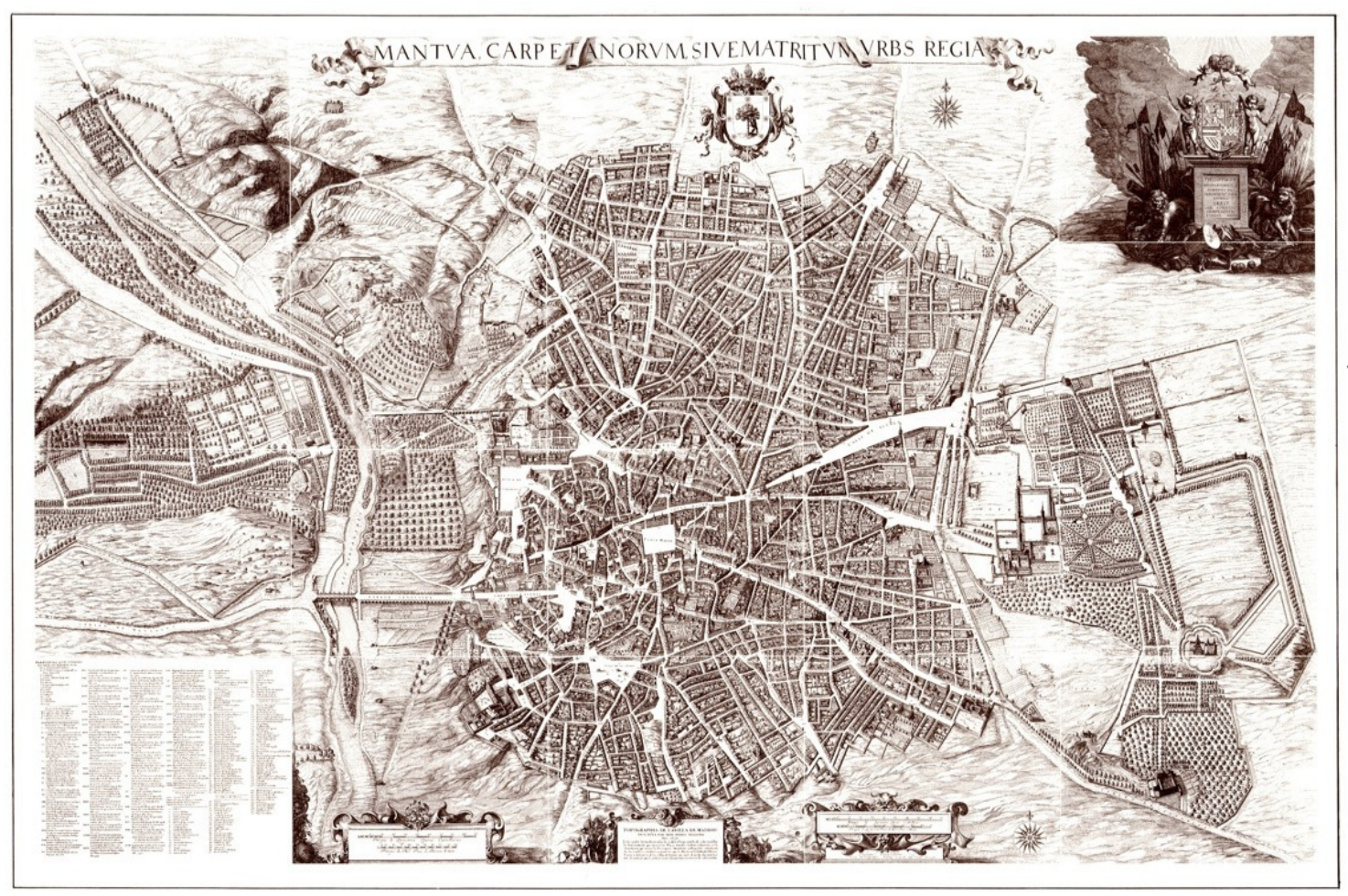

Figura 11 - Pedro Teixeira, Plano de Madrid, 1656 - Museu Municipal de Madrid.

Fonte: Wilkinson-Zerner, C., Op. cit., p. 157.

Além de Madrid, outras cidades também tiveram a iniciativa régia na arquitetura. Em Segóvia, o projeto realizado foi a fábrica real da moeda de Segóvia, "La Ceca de Segovia", construída na década de oitenta do século XVI, também com a participação de Herrera. Já em Valladolid, a intervenção se direcionou a dar uma nova imagem à "plaza mayor", após um incêndio ocorrido em 1561, que serviu como justificativa e incentivo para a reformulação desse espaço. $O$ rei estabeleceu, junto com o governo local, uma administração real para financiar a reconstrução do que se perdera. A reconstrução da "plaza mayor" recebeu atenção especial nesse contexto. O traçado original não foi muito modificado de fato, mas alguns terrenos foram expropriados para ampliar as ruas. A "plaza" se tornou mais regular, fixaram-se as alturas das janelas e os materiais que seriam utilizados, seguindo as diretrizes dadas por Felipe II. Em 1585, Juan de Herrera supervisionou 
tais obras e no ano seguinte apresentou projetos para o sistema hidráulico do lugar $^{170}$.

As "plazas" estavam entre as principais preocupações nas iniciativas urbanas de Felipe II. Segundo Chueca Gotia:

"A Espanha, no entanto, em fins do século XVI e devido à dedicação constante de Felipe II à ideia de elevar a arquitectura a um plano de grandeza severa e de rigor conceptual, consegue levar a cabo algumas criações de grande originalidade. Os conjuntos reais ou nobiliárquicos, por um lado, e as praças maiores regulares, por outro, constituem o que há de mais inovador no urbanismo filipino."171

Outro importante campo em que o monarca dedicou grande esforço foi para a criação de espaços de descanso e prazer, sobretudo no que diz respeito aos jardins de seus palácios. Esse foi um dos aspectos ressaltados por Geoffrey Parker ${ }^{172}$ em sua biografia clássica de Felipe II. Considerou-se até que o rei se preocupava mais com os jardins do que com as construções em si. E para tornar os espaços de descanso da monarquia e ajardiná-los, muitas outras obras eram necessárias.

O exemplo dos jardins de Aranjuez é emblemático para se compreender o desejo do monarca. Todo o jardim foi plantado. Nada daquele imenso terreno restava como parte da vegetação anterior, naturalmente nascida e crescida ali. Cada caminho foi pensado, nenhum traçado fora imposto por vias anteriores. Antes da criação dos jardins de Versalles, esse parque já exibia a monumentalidade de uma natureza criada, ordenada e controlada. Todas as plantas ali introduzidas foram cuidadosamente escolhidas por Felipe II, que controlava qualquer intervenção de seus arquitetos e jardineiros. Como aponta WilkinsonZerner:

\footnotetext{
${ }^{170}$ As referências documentais sobre essa participação encontram se no Archivo General de Simancas, Cámara de Castilla, leg. 412. Apud.WILKINSON-ZERNER, C. Op. cit., p.202.

${ }^{171}$ CHUECA CREMADES, F. Op. cit., p.113.

${ }^{172}$ Parker dedica um capítulo todo de seu livro para esse assunto, intitulado "O rei se diverte":

PARKER, G. Op. cit., pp.59-84.
} 
"Es el Rey, más que sus arquitectos, el que destaca como figura principal en el diseño de los jardines de Aranjuez. En ningún otro proyecto estuvo tan marcado su gusto personal ni fueron tan especificas $y$ carentes de ambigüedad sus instrucciones a los tracistas." ${ }^{173}$

A importância desses jardins para o rei era tamanha que ao final do reinado de Felipe II suas feições eram claras, enquanto que o palácio em si não podia ser visto da mesma forma.

Também percebemos o gosto por essa "natureza domesticada" nas cartas que o rei escreve às filhas durante sua estadia em Portugal, entre $1581 \mathrm{e}$ 1583. É curioso notar a maneira como Felipe II escreve sobre Castela, como tenta manter-se informado apesar da distância. As perguntas e comentários sobre seus jardins aparecem em muitos momentos dessas cartas. Podemos perceber a importância que têm para o monarca nos trechos a seguir:

"De acordo com o que dizeis, deve estar mais calor aí do que aqui, onde não está nenhum, com alguns dias muito frescos; e com tudo isto, não chove, ainda que isso não seja tão mau como para aí e para Aranjuez, de onde me descrevem grandes lástimas dos danos causados pela falta de chuva, e também do Escorial; a obra daí, escrevem-me que vai muito adiantada. Não sei se a tendes visto das vossas janelas, pois daí deveis vê-la muitas vezes."174

"Folguei muito com as vossas cartas e com as novidades que me dais de Aranjuez. Aquilo de que tive mais saudade foi do cantar dos rouxinóis que este ano não os ouvi porque esta casa é longe do campo." 175

A saudade do cantar dos rouxinóis também aparece em mais de uma vez nas cartas. Felipe II fala de plantas, frutos que envia às filhas, tenta buscar na memória todos os lugares mencionados pelas filhas em seus sítios reais. No

\footnotetext{
${ }^{173}$ Wilkinson-Zerner, C. Op. cit., p.148.

${ }^{174}$ Escreve essa carta às filhas de Tomar, a 01 de maio de 1581.
}

BOUZA, F. Carta para duas infantas meninas. Portugal na correspondência de D. Felipe I para suas filhas (1581-1583). Lisboa: Dom Quixote; Comissão Nacional para as comemorações dos Descobrimentos Portugueses, 1998, p.65.

${ }^{175}$ Carta escrita em Lisboa, a 16 de abril de 1582.

Ibdem, p.139. 
primeiro trecho citado das cartas acima, também percebemos a atenção que o monarca dedicava às obras do Escorial, que se mantinha mesmo quando era necessário que se ausentasse. $O$ rei comenta nas cartas sobre 0 andamento desse projeto enquanto ainda se encontrava em Portugal.

Além das cidades e dos jardins, o monarca se preocupou com seus palácios e com a conservação do patrimônio herdado de seu pai. Nesse sentido foi mantida a "Junta de Obras y Bosques", órgão responsável por gerir, conservar e aumentar o patrimônio dos Habsburgos na Espanha. Esse órgão foi criado por Carlos V e, segundo García Morales ${ }^{176}$, demonstra a verdadeira obsessão dos reis da Casa D’Áustria por manter a herança familiar, pensamento frequente em muitos de seus documentos, entre eles as cartas de Felipe II às suas filhas, enquanto o rei se encontrava em Portugal.

As pessoas que tinham funções dentro da "Junta de Obras y Bosques" eram servidores do rei, e a ele competia sua eleição. Para fazer parte da Junta era necessário ter nobreza comprovada. Ou seja, assim como chamamos a atenção para o fato de Herrera ser um nobre que conseguira recursos e ascensão através da arquitetura, não apenas os arquitetos teóricos, mas outras funções ligadas à arte de edificar ganhavam espaço dentro da burocracia dos Habsburgos na Espanha, criando novas possibilidades financeiras à nobreza. No entanto, a causa da decadência da Junta, extinta em 1768, foi seu próprio esgotamento econômico, devido ao excesso de nomeações para seus cargos.

Esse crescimento dos órgãos e dos cargos ligado à arquitetura e mesmo à engenharia, a partir das iniciativas da coroa espanhola, principalmente no reinado de Felipe II, se deve, sobretudo, à centralidade das iniciativas régias a despeito das encomendas feitas por nobres e religiosos espanhóis que exteriorizavam a configuração e disputas de poder entre as forças presentes dentro da Espanha. Até a construção do Escorial, segundo Checa Cremades ${ }^{177}$, a nobreza

\footnotetext{
${ }^{176}$ GARCÍA MORALES, M. V. Los artistas que trabajan para el Rey: La Junta de Obras y Bosques. Espacio, in: Tiempo y Forma, Serie VI, Historia del Arte, t. 3, 1990, págs. 123-136.

177 Os principais nomes ligados à iniciativa dos reis de também aderirem à linguagem clássica na arquitetura são os arquitetos: Juan Bautista de Toledo, Juan de Herrera, Francisco de Mora (1553 1610) e Juan Gómez de Mora (1586 - 1648).
} 
era a principal responsável por solicitar os serviços de artistas vindos da Itália, sendo, por isso, que a primeira tipologia construtiva renascentista realizada em território espanhol foi a do palácio. Dessa maneira, atuar como mecenas na arquitetura dava maior visibilidade ao poder real, sem deixar qualquer dúvida sobre sua maior importância no reino ao se comparar às construções realizadas pela nobreza.

Criar, reformar, ampliar e manter os palácios eram, para a monarquia, necessidades relacionadas à importância da imagem que essas construções expressavam de seus senhores. A maneira como essas iniciativas eram vistas por outros nobres do reino e por outros monarcas europeus também fazia parte das preocupações embutidas na incorporação da arquitetura à administração do reino

Vale ressaltar que, com o mesmo sentido de valorização do reinado presente, no momento em que Felipe II processava suas mudanças na arquitetura régia são impressas inúmeras obras de História da Espanha, que colocavam o período de presença muçulmana como a maior catástrofe do passado da península, o que poderia ser percebido em seus edifícios ${ }^{178}$. Vale lembrar que muitos edifícios muçulmanos permaneceram na Península lbérica após a reconquista, ou seja, a postura desses textos dos séculos $X V I$ e XVII não demonstrava uma atitude de recusa completa do passado islâmico preexistente ${ }^{179}$.

O livro do frei José de Siguenza, "História primitiva y exacta del monasterio del Escorial", deixa explícito que a construção do Escorial vinha para suplantar uma memória indesejada. Podemos perceber esse desprezo pelo passado medieval nesse trecho de Siguenza:

"Luego, en poniendo los pies en los umbrales de la puerta principal, se comienza a discubrir una majestad grande y desusada en los edifícios de España, que habia tantos siglos que estaba sepultada en

\footnotetext{
NIETO ALCAIDE, V. M.; MORALES, A. e CHECA, F. Op. cit.

${ }^{178}$ CAMARA MUÑOZ, A. Op.cit., p.21.

${ }^{179}$ NIETO ALCAIDE, V. M.; MORALES, A. e CHECA, F. Op. cit.
} 
la babárie ó grosería de los godos y árabes, que enseñoreándose de Ella por nuestro pecado, apenas nos dejaron luz de cosa buena, ni de primor, ni en letras, ni en las artes." 180

É na tentativa de se realizar essa arquitetura de personificação da Monarquia Hispânica e de estabelecer um novo papel para o arquiteto, que seria o responsável por esse projeto junto ao monarca, que Juan Bautista de Toledo inserese nos projetos arquitetônicos de Felipe II, em 1559. Diferentemente dos mestres responsáveis pelas obras de seu pai, Carlos V, que eram contratados para realizar trabalhos bastante específicos, Juan Bautista de Toledo não estava vinculado diretamente a nenhum projeto, mas sim ao rei.

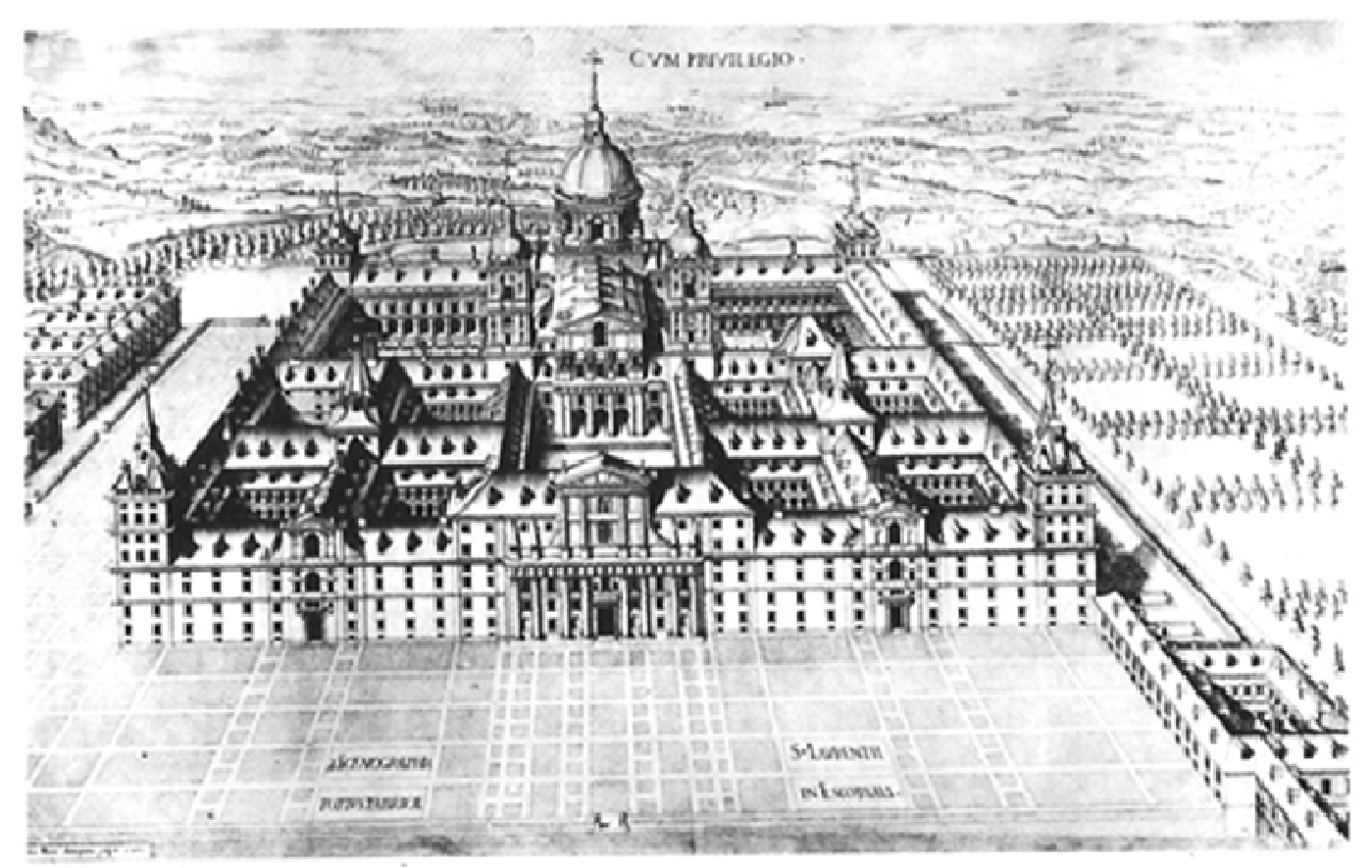

Figura 12 - Estampa de Pedro Perret, realizada a partir de desenho de Juan de Herrera para o Escorial.

Fonte: OLLERO, J. (ed.). Los Austrias. Grabados de La biblioteca Nacional. Madrid: Biblioteca Nacional, 1993.

${ }^{180}$ SIGÜENZA, Frei J. História primitiva y exacta del monasterio del Escorial. Escrita en el siglo XVI por el Padre Fray José de Sigüenza bibliotecario del Monasterio y Primer Historiador de Felipe II, arreglada por D. Miguel Sánchez y Pinillos. Madrid: Imprenta y Fundacion de M. Tello, Impresor de Câmara de S. M. Isabel la Católica, 23, 1881. Edición Fac-simile. Valladolid: Editorial Maxtor, 2003, p.264. 
O arquiteto inicia seus serviços estando muito próximo ao monarca, traçando novos edifícios, preparando os desenhos e os modelos para a sua construção. Após sua morte, sob o comando de Juan de Herrera, muitas das obras iniciadas por Juan Bautista de Toledo foram continuadas com a preocupação de se criar um todo coerente, com características que aproximassem suas obras. Sua principal virtude como servidor do rei foi, além de realizar desenhos e planos, consolidar um projeto uno e coerente para os edifícios régios ${ }^{181}$. Nesse aspecto, o Escorial permanece como o principal símbolo de Felipe II.

O Escorial é associado à imagem da defesa da fé por parte da monarquia de Felipe II. Podemos ver essa relação na estampa feita para ilustrar a publicação em Madrid, por Luis Sanchez, da obra de Luis Cabrera de Córdoba "Felipe Segundo Rey de España" (imagem 13). Trata-se de uma alegoria de Felipe II como defensor da fé católica, em uma calcografia realizada por Pedro Perret onde o monarca é colocado do lado direito da imagem, armado de uma espada na mão direita e uma "bengala de mando"182. A figura da mulher, que representa a Igreja, está atrás do rei, sendo protegida por ele, que se mostra numa postura ativa frente aos inimigos da fé católica.

\footnotetext{
${ }^{181}$ WILKINSON-ZERNER, C. Op. cit., 142.

${ }^{182}$ As considerações de Fernando Bouza sobre as estampas da Biblioteca Nacional relacionadas ao reinado de Felipe II estão em:

OLLERO, J. (ed.). Los Austrias. Grabados de La biblioteca Nacional. Madrid: Biblioteca Nacional, 1993, p.127.
} 


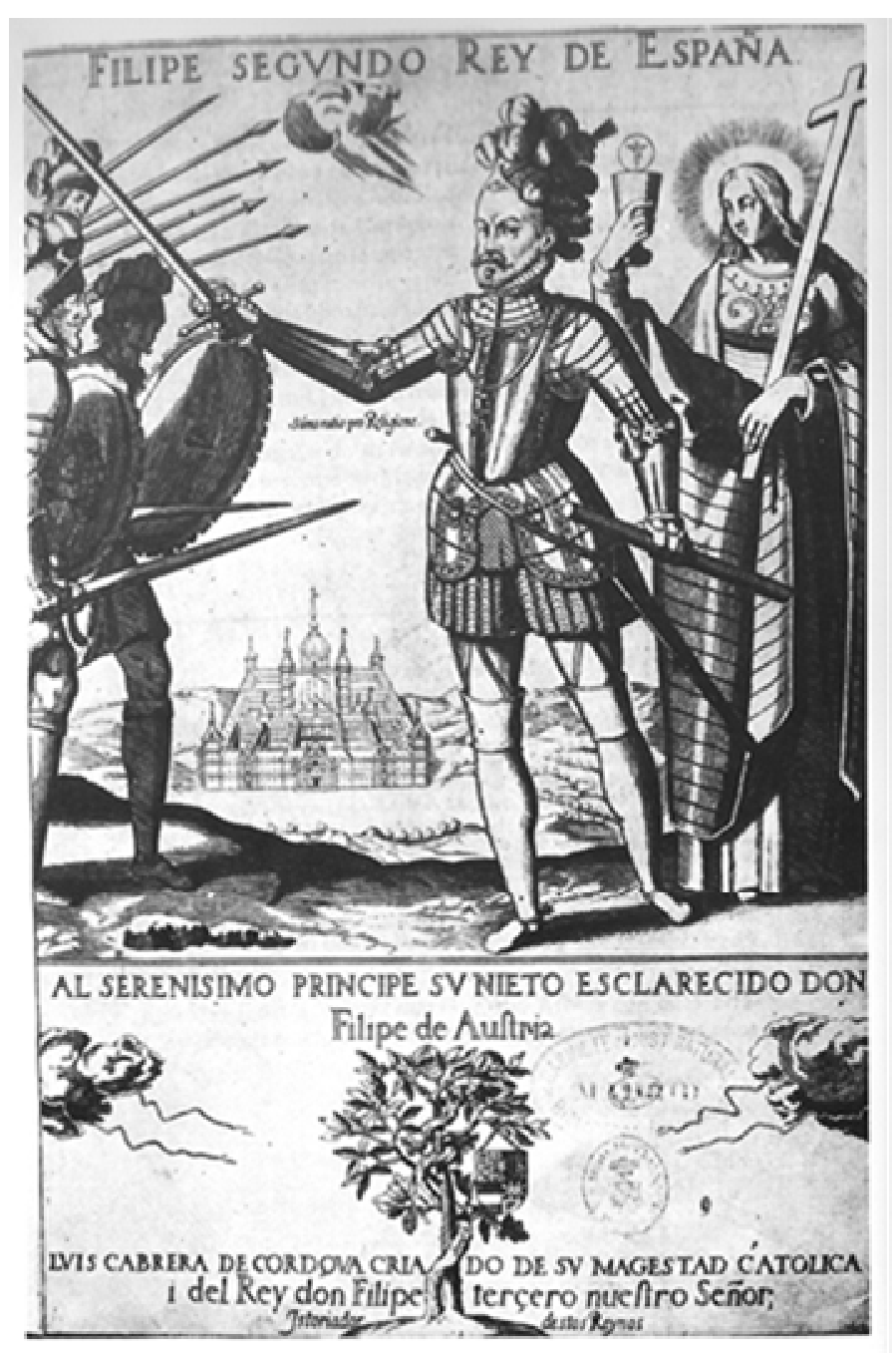

Figura 13 - Ilustração da obra de Luis Cabrera de Córdoba: Filipe Segundo Rey de España, por Pedro Perret -1619 .

Fonte: OLLERO, J.(ed.). Los Austrias. Grabados de La biblioteca Nacional. Madrid: Biblioteca Nacional, 1993, p.128.

Ao fundo da cena, não coincidentemente, está uma vista do Escorial, realizada a partir de um desenho de Juan de Herrera. Sobre o edifício está a inscrição "Summa Ratio pro Religione". Segundo Bouza Álvares ${ }^{183}$, a obra de Cabrera de Córdoba se dirigia ao neto de Felipe II como um modelo a ser seguido pelo próximo sucessor ao trono, que teria como principal dever a defesa da fé católica, inserida no contexto da Guerra dos Trinta Anos (1618-1648). Assim, percebemos como permanece, durante o reinado de seus sucessores, a memória

${ }^{183}$ Ibidem, p.127. 
desejada por Felipe II, através de um edifício, de seu comprometimento com a fé que professava.

Como aponta Maravall ${ }^{184}$, o Escorial se apresentava como uma experiência que antecedia o uso visual com apelo aos sentidos e afetos. Tal uso, característico do Barroco, que, segundo o autor, era a expressão cultural das primeiras décadas do século XVII, trazia em si um conceito mais amplo do que a simples concepção estética demontrada pelos autores dedicados à História da Arte, como já anunciamos anteriormente nesse texto. Ainda que não se concorde com essa "antecipação barroca" realizada na construção do Escorial, sem dúvida sua imagem foi utilizada posteriormente para fortalecer a imagem da Monarquia Hispânica como defensora da fé católica em meio às Igrejas Reformadas na Europa.

O Escorial, por ser um palácio-monastério afastado da maioria dos súditos do rei, lugar de refúgio e conforto espiritual do monarca, além de panteão real dos Habsburgos espanhóis, não podia, por sua localização, afetar os olhos e despertar o sentimento de devoção nos súditos do rei através de sua fachada austera e grandiosa. Se, em sua concepção, o Escorial foi pensado como um espaço isolado para o governante, uma maneira possível de utilizar sua imagem era a impressão e circulação da mesma. Isso atingiria um círculo maior de pessoas, mas ainda assim permaneceria relativamente restrita.

Vale ressaltar também que, se a maior parte dos súditos não podia ver o Escorial, Felipe II se importava em mostrá-lo aos visitantes estrangeiros em seu reino. Segundo Alícia Cámara Muñoz:

"el Monasterio fue mostrado con especial interés por el monarca a los
visitantes extranjeros, sobre todo si eran infieles. Símbolo del
catolicismo, estos visistantes podían ante él asombrarse de la
perfección y grandeza de la religión que lo cimentaba.[... La
monarquia identifico la beleza artística y la perfección de todo el
conjunto com la perfección de la religión católica, convirtinendo al
arte também em cuestión política"185

${ }^{184}$ MARAVALL, J. A. Op. cit.

${ }^{185}$ CAMARA MUÑOZ, A. Op. cit., p.39 
No ano de 1584, inclusive, o monastério foi visto por uma comitiva japonesa ${ }^{186}$. Além da preocupação com a visibilidade do Escorial e de seu uso como símbolo de um reino católico, Felipe II preocupava-se muito em saber a impressão que causava àqueles que podiam vê-lo. Um exemplo dessa preocupação aparecenos em uma de suas cartas privadas às filhas, enviadas durante o período em que realizou as entradas régias em Portugal. Nas palavras que escreveu em Lisboa, a cinco de março de 1582, o rei comentou as noticias que recebeu sobre a visita da Imperatriz, sua irmã, à Castela. Assim se dirigiu às infantas:

"Podeis calcular o que folguei com as vossas cartas e com as boas novidades que nelas me dais da minha irmã e de tudo o que se passou no Pardo até o momento em que as escreveste. $E$ assim as espero na quarta-feira, com o que aconteceu depois, ali como no caminho e em São Lourenço, e espero que me conteis tudo.

Para além da muita inveja que vos tenho por terdes visto a minha irmã, tenho também alguma da vossa estadia no Pardo, onde se deve estar bem, já que este ano choveu muito; é bom que esteja mais densa do que é costume porque assim não deixará de haver caça aí.

Não sei o que terá pensando o vosso irmão, daí e de São Lourenço, pois julgo que nunca aí tinha estado, ainda que não me lembre muito bem, e assim escrevei-mo e perguntai-lhe da minha parte como lhe pareceram os dois e se folgou nestes dias." 187

Sobre a ligação entre o governo dos Habsburgos e a Igreja na Espanha, nos deteremos um pouco adiante, no terceiro e capitulo dessa dissertação. O estudo da Ordem dos Jerônimos pode nos fornecer importantes elementos para compreender a criação da imagem pretendida por Felipe II com seus edifícios, pois são esses religiosos que vão ocupar muitos dos espaços construídos por iniciativa real.

Como nossa preocupação nesse capítulo é abordar a intervenção do rei na arquitetura e a importância de Herrera junto ao monarca, precisamos agora apontar outro aspecto extremamente relevante para se compreender a maneira

\footnotetext{
${ }^{186}$ Ibidem, p. 39.

187 BOUZA, F. Cartas para duas infantas meninas. Portugal na Correspondência de Filipe I para suas Filhas (1581-1583). Lisboa: Dom Quixote; Comissão Nacional para as comemorações dos Descobrimentos Portugueses,1998, p. 129.
} 
como Herrera participa do ordenamento dos territórios ibéricos de Felipe II: sua relação com a difusão do ensino das matemáticas no reino. 


\subsection{A Academia de Matemáticas e a política filipina de valorização das "ciências"}

Um dos aspectos mais interessantes para se compreender a atuação de Herrera como colaborador e influenciador dos projetos políticos de Felipe II está em sua atividade enquanto "homem das ciências", utilizando um termo anacrônico que tenta aproximar-nos do significado de sua atuação. Como apontamos no primeiro capítulo, sua preocupação com questões técnicas e seus estudos matemáticos estão entre os motivos pelos quais Herrera é frequentemente citado pela historiografia. Como aponta Esteban Piñeiro:

"En torno a los años centrales del siglo se produjo en España una auténtica convulsión científico-técnica auspiciada e impulsada por el nuevo monarca, Felipe II, y favorecida pela existencia, por vez primera, de una corte estable." 188

Dentro dessa "convulsão", Herrera era um dos responsáveis pelos incentivos régios. Além de sua contribuição, devemos ressaltar que o contexto ibérico da segunda metade do século XVI foi favorável ao monarca, juntamente com seu arquiteto, no desenvolvimento desse projeto de valorização do conhecimento matemático, que culmina com a criação da Academia de Matemáticas. Tal projeto foi possível devido à postura de incentivo do monarca, mas também se deveu à presença de bons professores e estudiosos que atuassem a seu serviço.

Devemos assim apontar que, na primeira metade do século XVI, o panorama "científico" espanhol apresenta, em muitos aspectos, uma continuidade das mudanças ocorridas no século $\mathrm{XV}$, sobretudo aquelas relacionadas ao conhecimento ligado à navegação, pois era uma necessidade em seu relacionamento com as colônias. Também, as discussões realizadas nas

\footnotetext{
${ }^{188}$ ESTEBAN PIÑEIRO, M. La ciencia en el siglo XVI español. In: HOURCADE, J. L. G,; YUSTE, J. M. M. Andrés Laguna. Humanismo, Ciencia y Política en la Europa Renacentista. Congresso Internacional (Segovia, 22-26 de noviembre de 1999). Madrid: Junta de Castilla y León; Consejería de Educación y Cultura, 2001, pp.22-40, p.23.
} 
universidades favoreceram o surgimento de importantes humanistas espanhóis entre os séculos $\mathrm{XV}$ e $\mathrm{XVI}{ }^{189}$. No que diz respeito às matemáticas, três importantes centros se destacavam nesses estudos: as Universidades de Alcalá de Henares, de Salamanca e a Casa de Contratación de Sevilha.

A Universidade de Salamanca figurava como a mais antiga da Península lbérica, fundada por iniciativa régia no século XIII, e apresentava no século XVI um grupo de importantes humanistas ${ }^{190}$. Entre eles estava Pedro Sánches de Ciruelo (1468? -1548) ${ }^{191}$, matemático e teólogo, aluno de Elio Antonio de Nebrija (1444-1522) ${ }^{192}$, que a partir de 1509 passou a ocupar a cátedra de teologia tomista da Universidade de Alcalá de Henares. Essa instituição fora criada sob a iniciativa do Cardeal Francisco Jiménez de Cisneros $(1436-1517)^{193}$, confessor

${ }^{189}$ BATAILLON, M. Erasmo y España. Estúdios sobre La Historia espiritual Del siglo XVI. Trad. Antonio Alatorre. México: Fondo de Cultura Económica, 1950.

190 José Pardo Tomás assinala que a cidade de Salamanca foi o maior centro produtor de livros "científicos" e técnicos de Castela e Leão no século XVI, comparando quantitativamente com os demais centros produtores de tais obras, ao lado de Valladolid, Medina del Campo, Burgos, Logroño, Zamora e Astorga.

PARDO TOMÁS, J. La difusión de la información científica y técnica. In: LOPES PIÑERO, J. A. (dir). História de la ciência y de la técnica en la corona de Castilla. Vol. III: Siglos XVI y XVII. Madrid: Junta de Castilla y León/ Consejería de Educación y Cultura.

${ }^{191}$ Pedro Sanchez de Ciruelo publicou algumas de suas aulas de matemática, como "Cursus quattuor mathematicarum artiun liberalium (1516)". Cópia digitalizada no site da Universidade de Sevilha: http://fondosdigitales.us.es/fondos/libros/715/14/cursus-quattuor-mathematicarum-artium-liberalium/

192 Antonio de Nebrija foi um importante humanista espanhol do século XV, autor da primeira gramática da língua castelhana "Gramática de la lengua castellana", em 1492. Sua trajetória está ligada tanto à Universidade de Salamanca, onde realizou seus primeiros estudos e foi professor de gramática, quanto à Universidade de Alcalá de Henares, onde também deu aulas de gramática e atou no projeto da Bíblia poliglota de Cisneros.

ACADEMIA LITERARIA RENASCENTISTA. Nebrija y la introdución del renascimento en España: actas de la III Academia Literaria Renascentista. Salamanca: Ediciones Universidad de Salamanca, 1988.

NEBRIJA, A. Gramática de la lengua castellana. Barcelona: Lenkgua, 2007.

${ }^{193}$ Além de confessor de Isabel, a Católica, o cardeal Cisnero ocupou o governo de Castela, após a morte de Fernando de Aragão, posição que ocuparia como regente até a chegada de Carlos à Castela (que viria a ser Carlos I, de Castela; e Carlos V, do Sacro Império).

FERNÁNDEZ ALBALADEJO, P. Fragmentos de Monarquía. Madrid: Alianza Universidad, 1992, p.43. 
de Isabel de Castela, homem de grande influência e que pretendia com a criação da nova universidade reformar o clero espanhol. Também promoveu a preparação da edição da Bíblia Poliglota Complutense ${ }^{194}$, finalizada poucos meses antes de sua morte, entre outras atividades como incentivador de atividades de humanistas espanhóis.

Também a cidade de Sevilha se afirmava como centro de estudos devido à Casa de Contratación, criada em 1503, reunindo um grupo de matemáticos intitulado o "circulo sevillano", em torno da figura de Hernando Colón (1488-1539) ${ }^{195}$, cosmógrafo, filho natural de Cristóbal Colón (Cristóvão Colombo). Esta instituição gozava de enorme prestígio não apenas dentro da Península lbérica, como aponta Esteban Piñeiro:

"La Casa de Contratación se configuró a lo largo del siglo XVI como la principal institución docente europea - dirigida a la formación de pilotos e maestres capaces de cruzar los océanos - y como un importante centro científico, fuente de una producción cartográfica que marcó la futura evolución de esta técnica en Europa." ${ }^{196}$

FERNÁNDEZ FERNÁNDEZ, C. La labor educadora de Cisneros y la primera biblioteca del renascimento de España. In: Anales de Documentación. Revista de Biblioteconomía y documentación. Vol. 5 Múrcia: Ediciones Universidad de Múrcia, 2002, pp. 81-97.

${ }^{194}$ O projeto da Bíblia Poliglota Complutense (1514-1517), editada pela Universidad Alcalá de Henares, é um dos grandes projetos humanísticos realizados nesta universidade de retorno ao texto original, com uma visão humanística da teologia e de exigência filológica e científica:

URBANO, C.M. Heroísmo, santidade e martírio no tempo das reformas. In: Península. Revista de Estudos Ibéricos, n.1, 2004, pp. 269-276.

${ }^{195}$ Hernando Colón, além de cosmógrafo era bibliófilo. Entre suas obras destaca-se um projeto de descrição e cosmografia da Espanha.

RODRIGUEZ TORO, Descripción y cosmografía de España (o itinerário) de Hernando Colón: sus "aportaciones" a los historiadores. In: Historia, instituciones, documentos. Sevilha: Departamento de Historia Medieval y Ciencias y Técnicas Historiográficas da Universidade de Sevilha, ํㅜ 27, 2000 , págs. 275-294.

WAGNER, K. La biblioteca colombina en tiempos de Hernando Colón. In: Historia, instituciones, documentos. Sevilha: Departamento de Historia Medieval y Ciencias y Técnicas Historiográficas da Universidade de Sevilha, № 19, 1992 , págs. 485-495

${ }^{196}$ ESTEBAN PIÑEIRO, M. La ciencia en el siglo XVI español. In: HOURCADE, J. L. G,; YUSTE, J. M. M. Andrés Laguna. Humanismo, Ciencia y Política en la Europa Renacentista. Congresso Internacional (Segovia, 22-26 de noviembre de 1999). Madrid: Junta de Castilla y León; Consejería de Educación y Cultura, 2001, pp.22-40, pp.29. 
Não é de se estranhar que, nessas primeiras décadas do século, a astronomia tivesse destaque entre os conhecimentos valorizados. Tal conhecimento era fundamental para um reino no qual a navegação era vital, e o desenvolvimento de assuntos relacionados a ela eram estimulados. Dentre os autores de maior projeção está o médico e astrônomo judeu de Salamanca, Abraham Zacuto (1450-1522) $)^{197}$, que influenciou a navegação dos reinos da Península Ibérica, sobretudo após sua fuga para Portugal, devido à expulsão dos judeus em $1492^{198}$.

Esse era o ambiente "científico" herdado por Felipe II quando passa a governar a porção ibérica dos domínios de seu pai, em linhas bem gerais. Juntamente com esse contexto, já bastante produtivo, muitas posturas de Felipe II revelam como seu reinado se voltou para o incentivo de ramos do saber que hoje consideramos científicos. A coleção de livros adquiridos pelo monarca demonstra um pouco desse aspecto de sua política, como já mencionamos anteriormente.

A educação recebida por Felipe II, que está em grande medida expressa em sua biblioteca, permitiu que surgisse o interesse em fomentar o ensino das matemáticas, o que se relacionava à valorização que o humanismo dava a esse conhecimento. Ao resgatarem o legado da antiguidade clássica, textos matemáticos gregos também foram recuperados e passaram a circular em novas edições pelas universidades européias e em outros círculos de leitores, o que aumentou o

\footnotetext{
${ }_{197}$ Abraham bar Samuel Abraham Zacut, conhecido em Portugal por Abraão Zacuto, nasceu em Salamanca, em meados do século XV, onde teria ensinado astrologia e astronomia. Não há precisão sobre as atividades que desenvolveu em Salamanca. Zacudo refugiou-se em Lisboa após a promulgação do decreto dos reis católicos, que obrigava os judeus à conversão ao cristianismo ou ao exílio. Há notícias de que já estaria em Portugal em Junho de 1493, ao serviço do rei D.João II. Viveu em Portugal apenas seis anos, pois em 1496 o rei $\mathrm{D}$. Manuel também decretou a expulsão dos judeus de seu reino que recusassem a conversão ao catolicismo pelo batismo. Zacuto refugiou-se em Tunes, no Norte de África, tendo depois passado para a Turquia, vindo a morrer na cidade de Damasco em ano posterior a 1522.
}

Em Portugal, elaborou as primeiras tabelas ou tábuas quadrienais do Sol para a navegação, no seu "Almanach Perpetuum", escrito entre os anos de 1473 e 1478, e reeditado em Leiria em 1496,

ALBUQUeRQUe, L. Zacuto, Abraão. In: SERRÃO, J. Dicionário de História de Portugal, Porto, Figueirinhas, 1981, Vol. VI.

${ }^{198}$ Ibidem. 
interesse sobre suas questões ${ }^{199}$. Nesse sentido, foi de grande importância a tradução para o castelhano dos livros I e IV dos "Elementos" de Euclides, realizada pelo matemático e cosmógrafo da Casa de contratação, Rodrigo Zamorano (15421623), em $1576^{200}$. Essa obra tinha várias edições desde o surgimento da imprensa, e fora traduzida para as línguas nacionais de vários reinos, segundo Mariano Esteban e Vicente Salavert ${ }^{201}$.

Um dos historiadores mais conhecidos como biógrafo de Felipe II, Geoffrey Parker, considera que o monarca não tinha bons conhecimentos de matemática, e que seria a necessidade de encontrar outros que se dispusessem estudá-la que o impulsionou a criar a Academia de Matemáticas. Para esse autor, a política desse reinado parece realmente ser a expressão dos desejos e do modo de governar de Felipe II. A participação de Herrera nesse projeto, segundo Parker, aparece apenas no que diz respeito à tentativa de dar maior alcance a esse interesse:

"En 1588, Herrera envió una propuesta con apoyo real de las Cortes de Castilla para que fundasen academias de matemáticas en todas las ciudades importantes, pero la mayoría de las ciudades votaran en contra de la propuesta a causa del coste."202

No entanto, essa postura não se mantém na historiografia, como colocamos anteriormente, e Herrera, junto com outros colaboradores de Felipe II, é lembrado pela historiografia por suas contribuições. Esteban Piñeiro inclusive chama Herrera de "auténtico ejecutor y gestor de la 'política' científica y técnica del monarca"203.

\footnotetext{
199 SÁNCHEZ RON, J. M. La ciencia en el Monasterio del Esocrial. In: JAVIER CAMPOS, F. e SEVILLA, F. de. Actas Del Simposium. Vol. 1. Escorial: Real Centro Universitario Escorial-María Cristina Pp.39-72, p.64-65.

${ }^{200}$ ESTEBAN PIÑEIRO, M.; SALAVRET FABIANI, V. Las matemáticas. In: LÓPEZ PINERO, J. M. (dir.) Historia de la ciencia y la técnica en la corona de Castilla. Vol. III. Siglos XVI y XVII. Madrid: Junta de Castilla y León, Consejería de Educación y Cultura, 2002, pp. 231-257.
}

201 Ibidem, p. 234.

202 Parker, G. Op. Cit. p. 74-75

203 ESTEBAN PIÑEIRO, M. La ciencia en el siglo XVI español. In: HOURCADE, J. L. G.; YUSTE, J. M. M. Andrés Laguna. Humanismo, Ciencia y Política en la Europa Renacentista. Congresso 
Essa política "científica" de Felipe II deve ser entendida como parte da prática de governar que exigia conhecimentos técnicos, sobretudo para um rei com inúmeros territórios, alguns muito extensos (como as colônias americanas), e tão diversos geograficamente. Tirar proveito desses lugares, e defendê-los da ocupação de outros reinos europeus, exigia o conhecimento de suas características naturais e geográficas.

Para a expansão marítima, que possibilitava o acesso, conquista e manutenção do tráfego entre a Espanha e suas colônias, foi necessário abrir rotas por mar, terra e fazer os rios navegáveis nas terras conquistadas. Também era necessário construir aquedutos, canais navegáveis, e realizar a irrigação de terras cultiváveis. Sanchez Ron considera que, "por ser una primera potencia política mundial, la dimensión práctica (o aplicada) de la ciencia, que el Estado necesitaba fuertemente, terminó ahogando el desarrollo científico"204. O autor complementa, julgando que esse é um dos aspectos que justificaria a peculiaridade das ciências na Península Ibérica, caracterizadas por seu apego à questão prática, enquanto em reinos que não tinham sob seu comando um mundo colonial tão vasto, como no caso da Inglaterra, os matemáticos e outros estudiosos teriam se voltado mais para questões científicas e teóricas bastante profundas.

Juntamente às necessidades ligadas à astronomia, cartografia e cosmografia, também há a figura do engenheiro, que se ocupava das questões de abastecimento de água e fortificação (engenheiro militar), entre outras. Esses serviços eram fundamentais tanto para as terras longínquas recém-adquiridas, como para os territórios europeus que possuía. Como é característico do momento, geralmente o que consideramos hoje como o campo de atuação da engenharia nem

Internacional (Segovia, 22-26 de noviembre de 1999). Madrid: Junta de Castilla y León; Consejería de Educación y Cultura, 2001, pp.22-40, p.34.

204 SÁNCHEZ RON, J. M. La ciencia en el Monasterio del Escorial. In: JAVIER CAMPOS, F. e SEVILLA, F. de. Actas Del Simposium. Vol. 1. Escorial: Real Centro Universitario Escorial-María Cristina pp.39-72 p.63. 
sempre era desempenhado exclusivamente por homens que se dedicavam apenas a tais atividades, ou que recebiam tal designação ${ }^{205}$. Como aponta García Tapias:

"El protagonista de esta eclosión técnica fue el ingeniero, cuya
función en el Renacimiento empezaba a ser definida, aunque a veces
bajo el epígrafe de "arquitecto" o de "maestro de obras", con los que
a menudo se difundía. En efecto, lo que hoy entendemos por
ingeniería, era ejecutado generalmente en el Renacimiento por
arquitectos y maestros de obras. A éstos se les valoran actualmente
sus obras de arquitectura en catedrales, iglesias y palacios, pero
menos sus obras de ingeniería. Así, al famoso Juan de Herrera se le
conoce más por ser arquitecto del Monasterio de El Escorial (que por
cierto también es una gran obra de ingeniería) que por haber resuelto
el problema de abastecimiento de agua a cuidades como Valladolid o
por haber inventado máquinas para cortar el hierro, por ejemplo."206

Como é lembrado por García Tapias, Herrera atuou também nesse aspecto. Já mencionamos sua relação com Juanelo Turriano, um dos engenheiros italianos que se dirigiram à Península lbérica para servir aos Habsburgos espanhóis. Era comum a vinda de grande número de engenheiros estrangeiros, sobretudo da Itália, para realizar obras na Península lbérica e que eram muito bem pagos pelos Áustrias ${ }^{207}$. Os estrangeiros formaram um primeiro grupo de servidores voltados a solucionar as necessidades próprias de uma monarquia que estava agregando mais territórios. Por esta mesma razão, aos poucos vai se formando uma escola propriamente espanhola de engenheiros, já que aqueles que atuam junto aos estrangeiros vão sendo formados em seus conhecimentos.

Entre estes engenheiros formados na Península Ibérica destacamos a figura de Cristóbal de Rojas (1555-1614), engenheiro militar, que iniciou sua aprendizagem nas obras do Escorial sob o comando de Juan de Herrera.

\footnotetext{
${ }^{205}$ ESTEBAN PIÑEIRO, M. Os oficios matemáticos en la España del siglo XVI. In: NAVARRO, Víctor; SALAVERT, Vicent L;. CORELL, M.; MORENO, E.; ROSSELLÓ, V. (coords.). Actes de les II Trobades d'Historia de la Ciencia i de la Tecnica: (Peníscola, 5-8 desembre 1992). Barcelona: Societat Catalana d'Història de la Ciència i de la Tècnica, 1993, pp.239-252.

${ }^{206}$ GARCÍA TAPIAS, N. Descubrimientos e invención técnica. La actividad de los inventores españoles. In: CARABIAS TORRES, Ana Maria (coord.). Las relaciones entre Portugal y Castilla en la Época de los Descubrimientos. Salamanca: Ediciones Universidad de Salamanca, 1996, pp. 165-180.
} 
Foi autor de uma obra sobre fortificação, intitulada "Teórica y práctica de fortificación", impressa em Madrid, em 1598. Essa obra foi o primeiro tratado de fortificação escrito em castelhano. Rojas enviou a obra a Herrera, solicitando seu parecer para editá-la. ${ }^{208}$

Ainda sobre a relação das atividades de Juan de Herrera com as questões ligadas à engenharia, enquanto arquiteto do rei preocupou-se com aspectos práticos da construção para viabilizar seus projetos arquitetônicos, como já mencionado. Segundo aponta Catherine Wilkinson-Zerner, a idéia de que a arquitetura derivava de técnicas baseadas nas matemáticas, em especial a geometria e as leis mecânicas, era corrente na Antiguidade, e Vitrúvio colocava máquinas e edifícios lado a lado em seus escritos. Segundo Zerner, a visão de Herrera sobre arquitetura estava muito influenciada pelo seu interesse pelas artes manuais. A autora aponta de forma elogiosa:

"Las alabanzas de Herrera hacia la habilidad manual no eran una postura puramente retórica. No tenía los prejuicios de su clase contra el trabajo útil; el joven soldado hidalgo, que había descubierto la ciencia y aprendido a dibujar, pronto osciló entre los diferentes dominios del trabajo intelectual y el trabajo manual. Esos dos extremos, popularmente considerados incompatibles, aparecieran ligados en él, como dijo muy a menudo a científicos e ingenieros que luchaban también contra el extendido prejuicio de la dignidad de las artes plásticas." ${ }^{209}$

Com os conhecimentos adquiridos através da colaboração com Turriano, o aprendizado com Juan Bautista de Toledo, toda a sua carreira enquanto arquiteto e matemático, e a confiança conquistada com os serviços prestados ao rei, Herrera se tornou uma das figuras centrais para se pensar o mecenato régio para invenções, o incentivo a publicações de caráter científico e a valorização dos estudos matemáticos.

Segundo Esteban Piñeiro, a partir de 1550, ano em que Felipe inicia seu governo como príncipe regente, a coroa inicia uma verdadeira

\footnotetext{
${ }^{208}$ CERVERA VERA, L. Intervención de Juan de Herrera en Ediciones de Libros. Madrid: Instituto de Valencia de Don Juan, 1996.

${ }^{209}$ ZERNER, C. W. Op. Cit., p. 29
} 
"institucionalização" das matemáticas. Entre os motivos enumerados pelo autor, a carência de especialistas que pudessem ocupar os ofícios matemáticos que o monarca pretendia criar aumentava a necessidade de instituir um centro para o ensino das matemáticas (geometria, aritimética e conhecimentos relacionados a esses dois ramos matemáticos) ${ }^{210}$. Podemos, dessa forma, considerar os argumentos expostos pelo autor como alguns dos aspectos que apontam os interesses que nortearam as ações de Felipe II como incentivador das "ciências" em seus domínios.

Na carta que Juan de Herrera escreveu a Cristobal de Salazar, secretário da embaixada da Espanha em Veneza, em 01 de janeiro de 1584, 0 arquiteto coloca como uma iniciativa sua pedir ao monarca que criasse uma Academia de Matemáticas:

"Su. Mag., a instancia y suplicación mía, a instituído uma cátedra de matemáticas que se lea en la corte, y ansí se va haziendo desde octubre acá, y créese que a de grande provecho para muchas coisas, y hasta agora non faltan oyentes, y entendemos que tampoco faltarán." 211

Em um artigo de 2003, o mesmo autor analisa a publicação de Herrera de 1584 entitulada, "Institucion de la Academia Real de Mathematica", uma espécie de estatuto da própria instituição ${ }^{212}$. Nesse texto, Herrera coloca como justificativa para a criação dessa academia a ineficiência das Universidades, sobretudo pelo seu número ínfimo de alunos, que não supriam as necessidades de homens dedicados aos conhecimentos matemáticos no reino. As aulas eram abertas a todos que se interessassem, mas tinha como público incentivado os homens de

210 ESTEBAN PIÑEIRO, M. Os oficios matemáticos en la España del siglo XVI. In: NAVARRO, Víctor; SALAVERT, Vicent L;. CORELL, Mavi; MORENO, Esther; ROSSELLÓ, Victória (coords.). Actes de les II Trobades d'Historia de la Ciencia i de la Tecnica (Peníscola, 5-8 desembre 1992). Barcelona: Societat Catalana d'Història de la Ciència i de la Tècnica, 1993,pp.239-252.

${ }^{211}$ Archivo General de Simancas - G.A. 165, fol.249. Apud. VICENTE MAROTO, M. I. Juan de Herrera y la ingenieria. In: ARAMBURU-ZABALA, M. A.(dir.) e GÓMEZ MARTíNEZ, J. Juan de Herrera e su influencia. Actas del simpósio. Camargo, 14/17 julio 1992. Santander: Unversidad de Cantábria/Fundación Obra Pía de Juan de Herrera, 1993, pp.79-89, p.81

${ }^{212}$ ESTEBAN PIÑEIRO, M. Las Academias técnicas en la España del siglo XVI. In: Quaderns D'Història de l'enginyeria. Volum V. Barcelona: Universitat Politècnica da Catalunya, 2003, pp.1018. 
todas as profissões relacionadas às diversas artes, ciências e técnicas. Essas profissões, enumeradas por Herrera, eram: aritméticos teóricos e práticos, geômetras "destros em medições", astrônomos, músicos, cosmógrafos, pilotos, arquitetos e fortificadores que possam desenhar cidades e fortalezas, engenheiros e maquinários que possam construir todo tipo de engenho, artilheiros e mestres em aparatos bélicos, encanadores e niveladores de águas para os aquedutos e canais de irrigação, relojoeiros, e, por fim, pintores e escultores.

Além de capacitar todos os homens que desempenhavam as atividades técnicas da época, Herrera apontava, como outro objetivo da Academia, a educação e instrução dos filhos dos nobres que eram criados na corte e palácio de sua majestade. Essa seria também uma forma de atualização das escolas de palácio estabelecidas nas cortes castelhanas, com algumas particularidades, como a maior importância que neste momento dava para os saberes práticos e matemáticos, e estar aberta a um conjunto de alunos mais amplo e diverso. Além disso, as leituras seriam em língua castelhana e não latim. Também foi colocada por Herrera a possibilidade dos alunos obterem o título da especialidade que estudavam depois que comprovassem o aproveitamento das aulas através de um exame, garantindo uma verdadeira institucionalização do exercício profissional dos técnicos, o que era uma novidade para o período. Como aponta Esteban Piñeiro, pela primeira vez na Europa estaba se propondo, de maneira clara, a "institucionalização" da formação e do exercício de atividades técnicas e científicas. ${ }^{213}$

Herrera teve papel fundamental na Academia. Felipe II, em cédula de 25 de dezembro de 1582, nomeia o cosmógrafo e cartógrafo português Juan Bautista de Lavaña (c.1555-1623) ${ }^{214}$, responsável pelas leituras. Pedro Ambrosio de Ondériz (? - 1596) seria seu ajudante, e Juan de Herrera estava encarregado de controlar as funções de ambos. Em 1591, apesar da Academia de Matemáticas ter

\footnotetext{
${ }^{213}$ Ibidem.

${ }^{214}$ Lavanha foi chamado a atuar para Felipe II após a viagem que o rei fez a Portugal, permanecendo nesse reino de 1581 a 1583. Além de ter se tornado professor na Academia de Matemáticas, também foi nomeado "engenheiro de Portugal" em 1586.
}

ARTUR, A.P.U. Aportações à Biografia de João Baptista Lavanha. In: Revista da Universidade de Coimbra. Coimbra: Universidade de Coimbra, vol. XXXVI, 1992, pp.395-408. 
passado a depender do Conselho das Índias, se mantêm o controle de Herrera sobre as atividades dos professores. Essa instituição sempre contou com professores de grande prestígio e alto nível científico, e essa é a razão de sua influencia, apesar de não ter alcançado os objetivos explicitados por Herrera. Este não conseguiu promover a institucionalização das atividades técnicas, pois a maior parte dos alunos era proveniente da nobreza e tinha como objetivo adquirir conhecimentos superficiais para sua promoção pessoal.

Segundo Alícia Cámara Muñoz, apesar de Herrera, ao longo de sua vida, ter mantido o controle dessa instituição através de seu cargo de diretor, as atividades de Juan Bautista Lavaña (João Baptista Lavanha) e Pedro Ambrósio Ondériz se destacaram por suas atuações nessa instituição, sobretudo devido à importância de suas obras escritas relacionadas à navegação ${ }^{215}$. Catherine Wilkinson-Zerner menciona importantes obras escritas por professores ligados às atividades que realizavam na Academia de Matemáticas. Podemos ter idéia dessa importância citando algumas obras de João Baptista Lavanha: "Regimento Náutico" (Lisboa, 1606); "Viagem de la Catholica Real Magestad del Rey D. Felipe N.S. ao Reyno de Portugal" (Madrid, 1622), "Breue Compendio de las cosas de España" (manuscrito no Escorial, 1616) e "Architectura Naval" (incompleto) ${ }^{216}$.

O objetivo de Herrera em divulgar os conhecimentos matemáticos era ainda mais amplo. Um projeto influenciado pelo arquiteto foi discutido nas Cortes de Madri por quatro anos, e tinha como objetivo criar escolas de matemáticas, com professores responsáveis pelas lições de Euclides, em algumas cidades espanholas. Apesar do apoio real, o projeto nunca foi posto em prática, devido à resposta negativa das cidades a esse intento. Herrera tinha, ao seu lado, Juan Bautista Lavaña, para tentar conseguir o apoio dos procuradores das cidades em que seriam ministradas as aulas e que se encontravam nas discussões sobre o tema nas cortes. As cidades que despertavam o interesse de Herrera eram: Burgos, Jaén, Valladolid,

\footnotetext{
${ }^{215}$ CAMARA MUÑOZ, A. Juan de Herrera y la arquitectura militar. In: ARAMBURU-ZABALA, M. A.(dir.) e GÓMEZ MARTíNEZ, J. Juan de Herrera e su influencia. Actas del simpósio. Camargo, 14/17 julio 1992. Santander: Unversidad de Cantábria/Fundación Obra Pía de Juan de Herrera, 1993, pp.91-103.
}

${ }^{216}$ WILKINSON-ZERNER, C. Op. cit., p.182. 
Toledo, Salamanca, Madrid, Soria, Segovia e Guadalajara. ${ }^{217}$ A Academia funcionou até 1625 , quando sua biblioteca foi doada ao Colégio Imperial Jesuíta ${ }^{218}$.

Para Esteban Piñeiro ${ }^{219}$, foram dois os motivos que provocaram essa negativa geral das cidades. O primeiro, de caráter puramente econômico, era a falta de recursos das cidades para arcar com os gastos dessas aulas. $O$ segundo, de caráter cultural e social, se referia à resistência das oligarquias locais que dominavam essas cidades e vilas, que eram incapazes de apreciar a importância dos conhecimentos técnicos difundidos por tal iniciativa.

A Academia de Matemáticas não conseguiu atingir os objetivos apresentados por Herrera. Não conseguiu expandir o ensino de matemáticas a outras cidades, e a instituição madrilena nunca realizou exames, nem mesmo emitiu certificados. As matérias que foram ensinadas acabaram por se configurarem de maneira a privilegiar a formação de cosmógrafos. Dessa forma, a instituição herreriana não consegue superar a situação de uma escola palaciana. ${ }^{220}$ No entanto, um êxito da Academia deve ser ressaltado: as atividades dos professores, sobretudo na realização de traduções de obras para o castelhano, tornaram conhecidas e acessíveis obras clássicas, de autores antigos e da época. Alicia Cámara Muñoz menciona a atividade Pedro Ambrósio Ondériz, professor de cosmografia na Academia de matemáticas e cronista das Índias, como tradutor de

\footnotetext{
${ }^{217}$ Na reunião das Cortes de Castela de 07 de dezembro de 1586 é colocada a ordem real de se estabelecer as escolas de matemáticas nas cidades castelhanas mencionadas.
}

Actas de las cortes de Castilla, Madrid, 15 vol (vol.09), apud. Wilkinson-zerner, p. 182.

${ }^{218}$ ESTEBAN PIÑEIRO, M. Las Academias técnicas en la España del siglo XVI. In: Quaderns D'Història de l'enginyeria. Volum V. Barcelona: Universitat Politècnica da Catalunya, 2003, pp.1018.

${ }^{219}$ Ibidem.

${ }^{220}$ Ibidem. 
Euclides $^{221}$; Cervera Vera cita 0 informe favorável escrito por Herrera para a tradução desse autor, realizada em $1584 .^{222}$

\section{Segundo Sanchez Ron:}

"La célebre Academia de Matemáticas fundada por Felipe II, y que entro em funcionamiento em 1582, estudo dirigida a la formación de cosmógrafos. Aunque como parte de sus actividades se vertieron al castellano obras de autores como Euclides (libros XI y XII de los Elementos), Arquímedes (Equiponderantes), Teodosio (Perspectiva y Especularia) y Apolonio (Cónicas), hay que tener en cuenta que se trataba de textos de geometría esenciales para la astronomía y el trazado de cartas geográficas y marítimas o, como en el caso de De los cuerpos flotantes de Arquímedes, útiles para las cuestiones relacionadas con la navegabilidad y seguridad de los navíos."223

Nesse mesmo sentido, percebemos outro aspecto fundamental da atividade de Herrera junto ao rei, como incentivador dos conhecimentos técnicos e científicos: sua influência para a publicação de livros, intervenção que estava voltada para a aprovação dos autores para a edição.

É fundamental ressaltar novamente sua preocupação de que esses livros se publicassem em romance castelhano, para facilitar o acesso dos interessados ao tema, que não necessariamente sabiam latim. $O$ castelhano possibilitava um maior número de leitores. Da mesma forma, as aulas da academia eram dadas em castelhano. A escolha da língua não é aleatória, e está relacionada à tentativa de centralização a partir de Castela. Se era para se adotar uma língua vulgar em comum, essa provavelmente revelava uma escolha por um reino como referência dessa unidade no projeto humanístico.

Segundo Cervera Vera, muitos livros foram editados em castelhano justamente para serem usados nas aulas da Academia de Matemáticas,

${ }^{221}$ CAMARA MUÑOZ, A. CÁMARA MUÑOZ, A. Arquitectura y Sociedad en el Siglo de Oro. Madrid: Ediciones El Arquero Textos Universitários, 1990, p.58.

${ }^{222}$ Cervera Vera menciona o exemplar dessa edição do livro "La perspectiva e especularia" de Euclides, traduzido por Ondériz, presente na Biblioteca do Escorial (localização: 72-VII-18)

CERVERA VERA, L. Op. cit., p.29.

${ }^{223}$ SANCHEZ RON, J.M. Op. cit., p.62. 
portanto, com a intervenção de Juan de Herrera. Como já mencionado, temos a tradução do livro de Euclides, "La perspectiva e especularia", pelo matemático espanhol Pedro Ambrosio de Ondériz, com dedicatória alusiva à Academia de Matemáticas. Também Cristóbal de Rojas, que fora professor de fortificação na Academia, solicitou o parecer de Juan de Herrera para editar seu tratado de fortificação intitulado "Teoría y Practica de fortificaccion, conforme las medidas u defensas destos tempos" ${ }^{\text {"24 }}$, que foi impresso em 1598, quando Herrera já havia falecido.

Outra obra impresa, com a intervenção de Herrera, foi a tradução ao romance castelhano do tratado de Alberti por Francisco Lozano, que foi mestre de obras na vila de Madrid. A obra foi enviada para o exame de Herrera em 1578, solicitando a licença e privilégio para imprimir a obra, o que se realizou em $1582 .{ }^{225}$ Também, o arquiteto real foi o responsável por aprovar a obra do médico sevilhano Simón de Tovar, "El examen y censura"226, que tratava da arte de navegar,impresso em 1595. Herrera influenciou ainda a impressão da tradução de Patricio de Caxesi para o castelhano do livro "Regla de las cinco ordenes de architectvra, de Jacome de Vignola" ${ }^{\text {"27, }}$, obra cuja impressão estava diretamente relacionada aos serviços que o próprio Caxesi desempenhava pintando afrescos no Alcázar de Madrid. Tal obraue recebeu licença para ser impressa em 1587.228

\footnotetext{
${ }^{224}$ VERA CERVERA, L. Op. Cit., p.62.

${ }^{225}$ Ibidem, p.23.

${ }^{226}$ Ibidem, p.45.

${ }^{227}$ Ibidem, p.38.

${ }^{228}$ Cervera Vera também menciona a interferência de Herrera na publicação das "Illustraciones genealógicas de los Catholicos Reyes, y de los christianissimos de Francia...", por Esteban de Garibay, que era cronista real. Por fim, menciona também o pedido do próprio rei para que Herrera examinasse a obra de Álvaro de Piña, que tinha como preocupação adaptar as datas do calendário juliano para o gregoriano, que passava a vigorar a partir 04 de outubro de 1582, mas que provavelmente não foi impressa.
}

Ibidem, p. 53 e 69. 
Essas atividades de Herrera não estavam diretamente relacionadas às suas funções como arquiteto do rei, por isso nessa documentação mencionada acima, o arquiteto assinava como "criado de Su Majestad".

Considerando sua atuação como incentivador do ensino de matemática no reino e na impressão de livros, percebemos que Juan de Herrera estava em sintonia com os desejos do monarca nesses assuntos, e que tinha uma posição confortável e de grande confiança dentro da corte de Felipe II, o que justifica que tradutores e autores castelhanos procurassem sua intermediação junto ao rei.

Essas considerações estavam em consonância com o que se passara a pouco em Portugal, onde a valorização dos conhecimentos teóricos necessários para a arte de navegar criou a imagem dos cosmógrafos como "homens de gabinete". Assim o eram Pedro Nunes (1502-1578), João Baptista Lavanha (c.1555-1623) e Pedro de Maris Carneiro (1642), que ocuparam o cargo de cosmógrafo-mor, responsáveis por aplicar os exames em todos aqueles que desejassem fazer cartas de marear, examinar as capacidades profissionais dos mestres oficiais, lecionar matemática para pilotos, sotapilotos, mestres, contramestres e guardiães, entre outras funções. Há uma diferença notável entre a formação dos primeiros navegantes e aquela processada em Portugal a partir da atuação de Pedro Nunes, com o saber menos dependente da prática cotidiana da navegação, sendo cada vez mais teórico ${ }^{229}$. No caso de Juan de Herrera, a tentativa de difundir o estudo das matemáticas em Castela também ia além da formação prática. Por isso a afirmação de que todos os interessados poderiam participar das aulas.

Pensando ainda na aproximação do saber matemático entre Portugal e Espanha, podemos perceber que alguns nomes ligados às matemáticas transitam entre os reinos ibéricos. Podemos ressaltar, inicialmente, o já mencionado Abraão Zacuto, judeu natural de Salamanca que se dirigiu a Portugal após a expulsão espanhola de 1492 e atuou na corte de Dom João II, escrevendo trabalhos

\footnotetext{
${ }^{229}$ POLÓNIA, M. A. Arte, técnica e ciência náutica no Portugal Moderno. Contributos da 'sabedoria dos descobrimentos' para a ciência européia. In: Revista da Faculdade de Letras HISTÓRIA. Porto, III Série, vol. 6, 2005, pp.09-20.
} 
que nortearam por muito tempo as ações dos homens que se aventuravam nos mares $^{230}$. Também o tão afamado Pedro Nunes, o primeiro a receber o título de cosmógrafo-mor em Portugal, teve parte de sua formação na Universidade de Salamanca. Os limites dos reinos peninsulares eram constantemente ultrapassados pelos homens que tinham novos estudos, que poderiam auxiliar os empreendimentos tanto de Castela quanto de Portugal.

No entanto, no que diz respeito à Academia de Matemáticas, não há consenso sobre a relação entre a instituição criada em Madrid e as aulas de matemáticas organizadas pelos professores portugueses que fizeram parte dessa instituição, anteriormente em Lisboa. Por exemplo, em uma recente obra de História da Ciência em Portugal, de Fiolhais e Martins, não há menção à Academia de Matemáticas que teria funcionado em Lisboa e que depois fora transferida para Castela durante o reinado de Felipe II, com a influência de Juan de Herrera. A ocorrência de reduzidos nomes de homens da cultura portuguesa nos materiais sobre História das Ciências, e a ausência da Academia de Matemáticas de Lisboa em grande parte da bibliografia consultada, chamam a atenção para o que parece uma lacuna sobre mais um capítulo das relações entre os conhecimentos construídos nos diversos reinos peninsulares ao longo do século XVI. Chama nossa atenção o fato da Academia de Herrera de ter sido criada após as visitas de Felipe II a Portugal, e por ter entre seus professores tantos portugueses.

Após apontar a importância da imagem real nos edifícos e das matemáticas dentro da burocracia do reino, devemos lembrar que a arquitetura e a participação de Herrera dentro da monarquia de Felipe II também criavam uma imagem do rei ligada à religião. Além disso, a própria história da construção do Escorial foi escrita por um religioso, Padre José de Siguenza, e a imagem de Felipe II, e do Escorial, foram lembradas pelos historiadores do século XVII como modelos na defesa da Igreja de Roma, como em Cabrera de Córdoba. Colocaremos, por fim, no próximo capítulo, como a religião também cria um elemento que aproxima os reinos da Monarquia Hispânica.

${ }^{230}$ FIOLHAIS, C.; MARTINS, D. Breve História da Ciência em Portugal. Coimbra: Gradiva, 2010. 
CAPÍTULO III - A ORDEM DE SÃO JERÔNIMO E A IMAGEM DE UMA MONARQUIA CATÓLICA 
Antes de morrer, Carlos V deixou uma série de escritos com observações sobre a situação em que se encontravam seus territórios, juntamente com instruções para o governo de seu filho e herdeiro, Felipe II. São três cartas para o futuro monarca. A primeira foi escrita em Palamós, em 4 de maio de $1543^{231}$, e deveria ser lida por Juan Zuñiga, seu tutor. A segunda, escrita na mesma localidade, em 6 de maio de $1543^{232}$, deveria ser lida apenas por Felipe II. A última foi escrita em Augusta, em 18 de janeiro de $1548^{233}$. Esses documentos, conhecidos como "Testamentos Políticos de Carlos V", apresentam-nos as principais preocupações que seu sucessor teria que enfrentar ao longo de seu reinado. As três cartas demonstram grande atenção à manutenção da religião cristã de Roma em seus territórios. Na primeira instrução enviada, Carlos V coloca explicitamente:

"Nunca permitáis que herejías entren en vuestros Reinos. Favoreced la santa Inquisición y tened cuidado de mandar a los oficiales de ella que usen bien y rectamente de sus oficios y administren buena justicia”234.

A preocupação com a religião mantém-se nos outros dois documentos, sendo que em suas últimas instruções, de 1548, coloca a importância

\footnotetext{
${ }^{231}$ Instrucciones de Carlos $V$ a Felipe II (Palamós, 4 de mayo de 1543). in: FERNÁNDEZ ÁLVAREZ, M. Corpus Documental de Carlos V. Salamanca: 1975, t. II, pp. 90-103. Disponível em: http://www.cervantesvirtual.com/historia/CarlosV/7_4_instrucciones.shtml. Acesso em 03 de dezembro de 2008.

${ }^{232}$ Instrucciones secretas de Carlos $V$ a Felipe II (Palamós, 6 de mayo de 1543). FERNÁNDEZ ÁLVAREZ, M. Corpus Documental de Carlos V. Salamanca: 1975, t. II, pp. 104-118. Disponível em: http://www.cervantesvirtual.com/historia/CarlosV/7_4_instrucciones.shtml. Acesso em 03 de dezembro de 2008.

${ }^{233}$ Instrucciones de Carlos $V$ a Felipe II sobre política exterior (Augusta a 18 de enero de 1548). In: FERNÁNDEZ ÁLVAREZ, M. (ed.) Corpus de Carlos V. Salamanca: Universidad de Salamanca, 1975, v. II, pp. 569-592. Disponível em: http://www.cervantesvirtual.com/historia/CarlosV/7_4_testamento.shtml. Acesso em 03 de dezembro de 2008.

${ }^{234}$ Instrucciones de Carlos V a Felipe II(Palamós, 4 de mayo de 1543), Op. cit.
} 
de Felipe II cuidar com grande atenção da eleição dos cargos eclesiásticos que estavam sob a responsabilidade real, devido ao direito de padroado $^{235}$ :

"Y cuanto a iglesias, dignidades y beneficios de los cuales el patronazgo, presentación o nominación os pertenecerá, debéis tener muy gran cuidado primeramente que sean proveídos en personas de letras, experiencia y buena vida y costumbres y ejemplo, y cualificadas por la administración buena de los dichos beneficios y cada uno respectivamente, según su ser y fundación. Y para esto informandoos gel maduramente y de gente que podáis hacer confianza, y fuera de sospecha y que no tenga otro fin que el servicio de Dios y descargo de vuestra conciencia. Y demás de esto ternéis advertencia que los tales administren y rijan sus iglesias y beneficios y hagan el oficio que cada uno es obligado, sin apartarse de ello sino con justas y legítimas causas, porque importa muy mucho por el servicio exaltación y conservación de nuestra salta fe y religión, bien vivir y salud de las almas de todos."

Dessa maneira, o reinado de Felipe II começava dentro das mudanças que se processavam a partir da reforma protestante. Seu governo se mantem, nesse contexto, sempre vinculado ao Papa, e de forma bastante ativa. Felipe II teve participação na convocação da terceira sessão do Concílio de Trento (1562-1563), manteve a preocupação em cristianizar os povos das colônias americanas e, com seu exército sob comando do Duque de Alba, investiu militarmente para manter os Países Baixos sob a tutela de Roma, em $1567^{237}$.

Apontamos anteriormente que, durante o reinado de Felipe III, os anos do governo de Felipe II são lembrados por historiadores, como Cabrera de Córdoba, como exemplo a ser seguido na defesa da Igreja Católica pelos reis

\footnotetext{
${ }^{235}$ Os reis espanhóis conseguiam interferir na eleição de alguns cargos religiosos desde o reinado dos Reis Católicos, mas sem o caráter legal desse direito confirmado por nenhuma bula papal. Durante a regência do Cardeal Cisneros em Castela e durante o reinado de Carlos V, os governantes espanhóis intensificaram seus pedidos para que o papa confirmasse o direito dos reis ao padroado, justificando seu pedido com os exemplos do grande empenho observado desses monarcas em defender a Igreja contra os muçulmanos. O direito ao padroado foi conseguido, oficialmente, em 06 de setembro de 1523, sendo confirmado na bula Eximia devotionis affectus. Esse documento concedia o direito de proposta e nomeação sobre as igrejas metropolitanas e catedrais e os demais benefícios consistoriais de todos os reinos e possessões da Espanha.
}

ROUCO VARELA, A. M. Estado e Iglesia en la España del siglo XVI. Madrid: Faculdade de Teologia San Dámaso, 2001, p. 239.

${ }^{236}$ Instrucciones de Carlos V a Felipe II sobre política exterior. (Augusta a 18 de enero de 1548), Op. cit.

${ }^{237}$ PARKER, G. Op. cit., p.122-124. 
espanhóis. Entre os símbolos lembrados da ligação entre rei e defesa da fé, o Escorial aparece como imagem central. Entre aqueles que guardaram a memória dessa construção temos o padre historiador José de Siguenza, também já mencionado anteriormente, que pertencia a Ordem de São Jerôniomo, a mesma que habitou o Monastério do Escorial.

Devemos ressaltar também que, na Península lbérica, dois importantes edifícios construídos pela monarquia foram habitados por monges jerônimos. Primeiramente, o mosteiro de Santa Maria de Belém, cujas construções se iniciaram em 1501, foi entregue aos Jerônimos e muitas vezes é mais conhecido pelo nome da ordem que o habita do que por seu nome original. Em segundo lugar, o mosteiro de San Lorenço El Real Del Escorial, iniciado em 1563.

Também, o mosteiro de Yuste, escolhido como lugar de recolhimento para os últimos dias do Imperador Carlos V, era habitado por esses religiosos, bem como muitos outros conventos que receberam heranças e doações de nobres e membros da família real, desde os primeiros anos da existência dessa ordem. O mosteiro de San Jerónimo de Yuste, em Cárcer, é hoje um dos dois últimos redutos das comunidades de monges dessa ordem, sendo que o outro se encontra em Santa María Del Parral, em Segóvia ${ }^{238}$.

Dessa maneira, devemos pensar a relação entre monarquia e monges jerônimos, para compreender sua vinculação à imagem do rei como defensor da Igreja nesse momento.

\footnotetext{
${ }^{238}$ Os dados foram retirados do texto de Francisco Javier de Campos Fernandez de Sevilla, fundador e director do "Instituto Escurialense de Investigaciones Históricas y Artísticas", ligado ao Real Centro Universitário Maria Cristina, no Escorial:

FERNANDEZ DE SEVILLA, F. J. C. Los reyes de España y la orden de San Jeronimo. Texto disponível na web em: http://www.javiercampos.com/files/Los\%20Reyes\%20de\%20Espana\%20y\%20La\%20Orden\%20de\%2 0San\%20Jeronimo.PDF , acesso em 20/janeiro/ 2011.
} 


\subsection{A Ordem dos Jerônimos}

Segundo Frei José de Siguenza, a justificativa para a escolha da Ordem dos Jerônimos, da qual fazia parte, para residirem no Escorial, estava na particular devoção de Felipe II em relação à Ordem:

"(...) y aunque es verdad que él [Felipe II] desde sus primeros años habia tenido particularísima devocion á Ordem de San Jerónimo, no se puede negar sino que haberla escogido su padre para acabar el último tércio de su vida y estar en ella sepultado, le fué gran despertador para resolverse en sus intentos." 239

Além da presença desses monges nos dois edifícios construídos por iniciativa régia, mencionados anteriormente, a Ordem dos Monges de São Jerônimo guarda inúmeras especificidades e ligações estreitas com o território ibérico e suas monarquias, que ajudam a entender a relação estreita entre reis e jerônimos, resultado da "devoção" apontada por Siguenza.

Segundo Cândido Dias dos Santos ${ }^{240}$, a Ordem de São Jerônimo surgiu em Portugal e Espanha a partir das experiências de vida eremítica na Itália do século XIV. Como inspiração para aqueles que desejavam abandonar sua vida familiar para viverem isolados do mundo, era freqüente a referência à vida de São Jerônimo no deserto de Calcis ${ }^{241}$. Nesse momento surgem várias famílias religiosas,

${ }^{239}$ SIGÜENZA, J. Op. cit, p.18.

${ }^{240}$ SANTOS, C. D. Os monges Jerônimos em Portugal na Época dos Descobrimentos. Lisboa: Instituto de Cultura e Língua Portuguesa, $1^{\text {a }}$ Ed., 1984.

As informações para o autor traçar a história da ordem dos Jerônimos encontram-se em dois documentos:

SIGUENZA, J. Historia de la Orden de San Geronimo. Madrid, 1600-1605, 2 vol ( $2^{\underline{a}}$ ed., Madrid, 1907-1909)

VEGA, P. Crónica de la orden de Sant Heronymo. Alcalá de Henares, 1539.

241 São Jerônimo (c.341-420), segundo os escritos religiosos, era da Dalmácia (hoje Croácia). Converteu-se ao Cristianismo em Roma e depois se tornou monge. Viajou à Síria e Palestina e passou 5 anos como eremita em Kalsis (Síria), aprendendo hebraico. Em 386 optou por vida de 
como os jesuatos (em 1355), os frades eremitas de São Jerônimo, estes últimos originando, posteriormente, a Congregação dos Frades Eremitas de São Lourenço, em Fiesole (em 1360).

Ainda segundo Dias Santos, na Espanha a divisão e formação da Ordem dos Monges Jerônimos teria se dado no século XV, com o surgimento da Congregação da Lombardia, resultante de uma cisão dos monges desse território provocada por Lope de Olmedo, que desejava criar uma ordem específica para os jerônimos em substituição à ordem de Santo Agostinho, que seguiam. O grupo que se formou em torno de Olmedo ficou conhecido como "Isidro", devido ao nome do mosteiro de Santo Isidro que fundaram. Esses monges uniram-se novamente aos Jerônimos em 1567, por ordem de Felipe II. ${ }^{242}$

Já em Portugal, a formação de um grupo de monges jerônimos se deu através de um discípulo português de um monge terceiro franciscano, chamado Tommaseccio. Após a morte de Tommaseccio, seu discípulo entrou em contato com núcleos de eremitas espanhóis em Orusco, Ambite, Javea, Castañas, Villaescusa e Guisando. A partir daí se difundiu essa forma de vida religiosa em Portugal, sendo que, em 1390, o Fr. Vasco comprou a quinta de Penhalonga, próxima a Sintra, para servir como refúgio aos homens que buscavam seguir esse ideal de vida parecida com São Jerônimo.

No primeiro dia do mês de abril do ano de 1400, o papa Bonifácio IX, pela Bula Piis votis fidelium, autorizou a construção de dois mosteiros em Portugal (Penhalonga e São Jerônimo de Mato) ${ }^{243}$. Nesse momento se dá em Portugal a passagem da vida eremítica, sem o ordenamento por uma regra

estudos monásticos em Belém, sendo pioneiro nos estudos bíblicos. Fez versão latina da Bíblia, chamada Vulgata.

LOYN, H.R. Dicionário da Idade Média. Trad. Álvaro Cabral. Rio de Janeiro: Jorge Zahar Ed., 1997.

${ }^{242}$ SANTOS, C. D. Op.cit., p.06 e p.134-5.

${ }^{243}$ Santos menciona o documento sobre a compra dessa propriedade com a seguinte localização: Arquivo Nacional da Torre do Tombo, Penha Longa, M.1, número 10. Apud. SANTOS, C.D. Op. cit., p.134. 
específica e uma hierarquia de religiosos, para a vida cenobítica dos que passavam a ser chamados monges jerônimos.

Segundo o Padre Siguenza, em sua história da Ordem de São Jerônimo, a passagem da vida eremítica à vida cenobítica ocorrera devido a excessos cometidos por eremitas e beguinos, que as autoridades eclesiásticas tentaram controlar. Como viviam sem regra, muitos eram olhados como suspeitos de heresia ${ }^{244}$. Segundo José Mattoso, há uma tendência acentuada ao surgimento de ordens monásticas a partir de grupos de eremitas no final da Idade Média. O mesmo autor também aponta que os eremitas procuravam lugares desertos, mas sempre estavam perto de um burgo ou de uma estrada importante, tinham fácil comunicação com as principais vias e podiam também se ocupar da hospitalidade e da recepção de peregrinos. Era comum alguns desses eremitas passarem para as ordens de Cister, Prémontré e dos Cónegos Regrantes de Santa Cruz de Coimbra ${ }^{245}$.

Esse englobamento de uma ermida a uma instituição ou ao poder de um protetor só passa a acontecer a partir do século XIII, pois antes predominava a idéia de serem fundadas com influência do movimento gregoriano e de sua idéia de libertas, ou seja, procuravam se tornar independentes dos poderes civis e da nobreza, como explica o autor: "Ou se estabeleciam sem as garantias canónicas do dote necessário para fundar uma igreja, ou obtinham carta de liberdade dos primeiros protectores ou protecção da autoridade papal ou couto de el-rei."246

No entanto, essa concepção não se mantêm. Em um estudo de José Rodríguez Molina ${ }^{247}$, da Universidade de Granada, podemos perceber uma extensa lista de doações realizadas por membros da monarquia espanhola para as fundações religiosas dos monges jerônimos e, a partir disso, suas intensas relações

${ }^{244}$ SIGUENZA, J. Historia de la Orden de San Geronimo. Tomo II, p.34. Apud. SANTOS, C.D. Op. cit. p.134.

\footnotetext{
${ }^{245}$ MATTOSO, J. Religião e Cultura na Idade Média Portuguesa. Lisboa: Imprensa Nacional Casa da Moeda, 1982.

${ }^{246}$ Ibdem, p.126.

${ }^{247}$ RODRÍGUEZ MOLINA, J. El monastério de San Jeronimo de Granada. Patrimonio y "más allá". In:
} Gazeta de Antropogía, n. 25, 2009. Disponível na web em:

http://www.ugr.es/ pwlac/G25_15Jose_Rodriguez_Molina.html Acesso em 22/jan./2010. 
com a nobreza espanhola. Um exemplo citado é o mosteiro escolhido por Carlos V, pai de Felipe II, para passar seus últimos anos de vida, San Jerónimo de Yuste, em Cáceres, que existia desde 1407, mas teve suas dependências ampliadas para receber, em 1556, o imperador e as pessoas que o acompanhavam, que eram em número de sessenta ou setenta. Também, muitos conventos e monastérios foram fundados por D. Enrique Enríquez de Guzmán, tio do rei Católico Fernando de Aragão.

A relação entre os jerônimos, os governantes na Península lbérica e pessoas próximas à corte se mostra como um aspecto importante das relações entre Igreja e monarquia no século XVI espanhol. Para os monges, segundo Mattoso $^{248}$, não havia incoerência entre essas doações e os ideiais de pobreza valorizados pela Igreja, pois as doações traziam alívio espiritual àqueles que as realizavam. O próprio José Rodríguez Molina menciona que, nas cartas de doações dos reis para o mosteiro, constavam entre os motivos de tal ação: garantir o sustento dos monges e outras pessoas do monastério; para que os monges rogassem a Deus pelas vidas dos reis e por seus estados, filhos, pela alma de seus progenitores e pelas deles mesmos; para provisão do monastério e seus edifícios; para a manutenção do culto divido; pela graça de uma vitória militar alcançada. No entanto, essa consideração não soluciona o nosso problema em compreender os motivos que faziam os monarcas estarem tão próximos especificamente dos monges jerônimos.

Segundo David Rodríguez Luna ${ }^{249}$, que estuda a história da Ordem de São Jerônimo da perspectiva de um homem religioso de nossos tempos, os jerônimos buscaram praticar a caridade comum aos monges que seguem essa regra através da hospitalidade. $O$ autor considera que essa hospitalidade se estendia desde aos mais pobres até aos nobres, e mesmo aos reis. Aliando essa característica à itinerância da monarquia, ao longo dos séculos $\mathrm{XV}$ e XVI,

\footnotetext{
${ }^{248}$ MATOSO, J. Op. cit.

${ }^{249}$ RODRíGUEZ LUNA, D. Algunos aspectos de la caridad en la orden de San Jeronimo. In: JAVIER CAMPOS, F. e SEVILLA, F. (coord..). La Iglesia española y las instituciones de caridad. Escorial: Ediciones Escurialenses; Real Centro Universitario Escorial-María Cristina, 2006, págs. 923-950.
} 
encontraríamos uma justificativa para a proximidade entre os reis castelhanos e esses religiosos.

Poderíamos contar como exemplos dessa relação de acolhimento dos reis pelos monges, e que reforçariam a postura do autor, a permanência de Carlos V no mosteiro toledano de Santa María de La Sisla por um tempo como retiro, devido à morte de sua esposa, a imperatriz Isabel. Os reis Católicos ficaram em 1480 no mosteiro de San Jeronimo de Guisando, em seu percurso de Toledo a Medina Del Campo, onde Felipe II costumava passar seus fins de semana antes de construir o Escorial. Por essa freqüência de visitas régias aos mosteiros ligados à Ordem de São Jerônimo, vários desses monastérios contavam com hospedaria real, ou seja, aposentos especialmente preparados para os monarcas. Entre os mosteiros com esses aposentos reais estavam: Santa María Del Parral (em Segóvia), San Jerónimo El Real em Madrid, Santa María de Guadalupe e São Jerónimo de Yuste (Cárceres).

No entanto, considerar que a proximidade entre a Ordem de São Jerônimo e as monarquias ibéricas se deve apenas a esse aspecto apontado por Luna nos parece demasiadamente simples. Segundo Francisco Javier Fernández de Sevilla $^{250}$, essa relação se deve, principalmente à especificidade da origem e expansão desse grupo de religiosos. Em primeiro lugar, os fundadores da ordem, Pedro Fernández Pecha e Fernando Yáñez de Figueroa, eram religiosos nobres da câmara de Don Alfonso de Onceno (1311-1350).

Outra particularidade deve ser levada em consideração. A princípio a ordem era exclusivamente espanhola, o que deve ter atraído a simpatia dos monarcas pelas vantagens de não precisarem lidar com os superiores estrangeiros e decisões capitulares adotadas em territórios estranhos aos seus domínios. A expansão da ordem também se dá exclusivamente no território peninsular, o que faz com que Siguenza considere essa ordem como "una religión

${ }^{250}$ RODRÍGUEZ LUNA, D. Op. cit. 
natural de España y de españoles, nacida, criada y sustentada dentro de sus términos, sin haber querido jamás tráspasar sus lindes."251

Dessa forma, podemos citar alguns episódios que demonstram a estreita relação estabelecida entre monarcas e monges jerônimos, em especial desde o período dos Reis Católicos até Felipe II. Notamos, nesse recorte cronológico, que inúmeras vezes tais religiosos estiveram a serviço da coroa, o que foi reiterado por diferentes monarcas e sempre valorizou a Ordem de São Jerônimo. Segundo o mesmo autor:

"Los RR. Católicos mantuvieron unas relaciones estrechas y sinceras que demuestra el aprecio institucional y personal que les unía con la orden, en general, y con algunos religiosos en particular; en la misma medida, los jerónimos se entregaron rendidamente a los monarcas para que utilizasen y se sirviesen de la orden como cosa propia"252

Um dos serviços realizados para a coroa no tempo dos reis católicos foi a reforma da Ordem Militar de Santiago, em 1492. Também Dom João III, de Portugal, pediu aos monges jerônimos que realizassem a reforma do Convento de Tomar, sede geral da Ordem Militar de Cristo.

Carlos V, em 1516, ao ser informado da difícil situação entre espanhóis e indígenas na ilha de Hispaniola, pediu à ordem para tratar dessa questão. Apesar de não claramente expresso, os serviços que prestariam ao rei se assemelhavam em muito aos de um governador, ainda que sem esse título. Ainda assim, os projetos escritos pelos jerônimos para atuarem nas colônias americanas não foram postos em prática ${ }^{253}$.

O contato mais notável entre imperador e monges jerônimos se dá no final da vida do governante, quando decide passar seus últimos dias em Yuste. Quando morre o Imperador, a ordem passa a ter grande protagonismo nos

\footnotetext{
${ }^{251}$ SIGUENZA, J. Apud. RODRíGUEZ LUNA, D. Op. cit., p. 212

${ }^{252}$ FERNANDEZ SEVILLA, J. C. Op. cit., p. 08.

${ }^{253}$ Ibidem, p. 08.
} 
rituais fúnebres, pois tinha a vantagem de ter o corpo enterrado em um de seus monastérios.

O fato de não ser uma ordem religiosa mendicante, ter caráter senhorial pela origem da maioria de seus monastérios, muitos construídos por ordem do monarca e de seus familiares, as doações que recebiam, sobretudo em testamentos de membros da nobreza e seu reduzido número de indivíduos, que serviam como estímulo a ser uma religião onde era possível viver uma espiritualidade em caráter pessoal, também auxiliou no interesse da coroa.

Podemos, neste ponto, levantar uma hipótese sobre a relação entre os mosteiros tidos como símbolos pelos monarcas de Portugal e Espanha, Belém e Escorial, terem monges jerônimos em suas dependências, baseada em algumas sugestões percebidas na leitura bibliográfica.

No livro “Demeures D’Éternité”254, o autor aponta que em carta de Felipe II ao Frei Juan de Borja, escrita em Guadalupe, em 1572, o monarca expressa sua admiração ao Mosteiro dos Jerônimos em Belém. O autor classifica esse interesse do rei espanhol como uma "admiração ciumenta", e aponta a rivalidade em termos monumentais com essa obra para a construção do Escorial: Felipe II então desejava um edifício com a mesma monumentalidade e símbolo do poder real que representava o Mosteiro de Nossa Senhora de Belém para os monarcas portugueses. Dessa forma, ainda segundo o autor, a Ordem dos Jerônimos ganha vulto também como uma forma de aproximar os reinos da península, o que já estava sendo realizado na política através da prática de casamentos de Dom Manuel com infantas espanholas ${ }^{255}$. Tais casamentos selavam um acordo entre os reinos e possibilitavam a geração de herdeiros que, inclusive, poderiam ser senhores de toda a península, o que de fato aconteceu, com a sucessão da coroa portuguesa, depois da morte do cardeal Dom Henrique, por Felipe II, em 1580.

\footnotetext{
${ }^{254}$ GUILLAUME, J. (org.). Demeures D’Éternité. Eglises et chappelles funéraires aux XVe et XVle siècles. Paris: Picard, 2005.

255 Dom Manuel casou-se, respectivamente, com três infantas espanholas: Isabel de Aragão (14701498) Maria de Aragão (1482-1517) e Leonor da Áustria (1498-1558), irmã do imperador Carlos V.
} 
Como aponta Caterine Wilkinson-Zerner ${ }^{256}$, Felipe II era o monarca mais atento e bem informado sobre as demais residências e edificações realizadas pelos governantes europeus que lhes eram contemporâneos. A autora indica que ele recebia informações de primeira mão de edificações principescas na Inglaterra, França e Flandres. Apesar de não citar, dada a proximidade espacial e de parentesco entre esses reinos, Portugal era um dos espaços de observação e de rivalidade do poder de Felipe II.

Vale lembrar que o autor português Domingos Tavares ${ }^{257}$, mesmo ao ressaltar as contribuições de Portugal junto à monarquia espanhola, a partir da União das Coroas Ibéricas, não sugere que as construções de Felipe II foram realizadas por motivo de inveja de Portugal, mas ressalta que há contribuições de Portugal para a cultura espanhola com a União das Coroas Ibéricas.

Segundo Javier Campos, ao realizar a construção do Monastério de San Lorenzo El Real, Felipe II "crea en el Escorial una Ciudad de Dios en la que él es Princeps et imago no tan ideal de ese imperio político-religioso como representante de la dinastía que encarna en su persona por voluntad y designios divinos (...)"258

Tais considerações nos colocam a importância da simbologia expressa no Escorial, através da arquitetura (nesse sentido a participação de Herrera) e da escolha da ordem religiosa que abrigaría. Sendo uma das preocupação de Felipe II manter a religião em seus territórios, esse era um dos aspectos a serem ressaltados nos seus varios territórios, apesar das diferenças preservadas entre seus reinos. Os jerônimos também valorizavam o que havia de mais ibérico no clero católico, devido à sua origem, e dessa maneira aproximavam os reinos peninsulares, entre eles Portugal, o último a fazer parte da Monarquia Hispânica.

\footnotetext{
${ }^{256}$ Wilkinson- Zerner, C. Op. Cit.

257 TAVARES, D. Op. cit., p. 37.

${ }^{258}$ FERNANDEZ DE SEVILLA, J. C. Op. cit., p. 27.
} 


\subsection{O aspecto sagrado do Escorial e a Ordem de São Jerônimo}

Ao eleger os jerônimos como moradores de São Lorenzo Del Escorial, Felipe II colocou a ordem no lugar de protagonistas no panorama eclesiástico. A partir de então, após o capítulo geral em abril de 1561 e a aceitação dos jeronimos à oferta do monarca, tudo girava em torno do Escorial e, desta forma, em torno também da Ordem de São Jerônimo. Segundo Javier Campos:

"Ningún otro monarca español ha mantenido nunca una relación tan intensa y continua con una orden religiosa como Felipe II con la de San Jerónimo; relación que llegó a convertirse en una vinculación tan estrecha e íntima que solo puede ser comprendida si se acude a la figura del rex-sacerdos."259

Entre o que ficou exposto na Carta de Fundación y Dotación de San Lorenzo, cujo texto foi confirmado em capítulo geral de $1567^{260}$, o rei expressava seu desejo de que o prior e os demais ofícios da ordem fossem eleitos por ele, que o prior não acumulasse outros cargos dentro da ordem, ainda que fossem temporários, e que se rezasse missa diariamente ao rei, o que se manteria, com algumas modificações, após a morte do monarca. ${ }^{261}$

Com a União das Coroas Ibéricas, também entram no território governado por Felipe II os monges jerônimos portugueses, que apresentavam completa independência em relação aos seus irmãos espanhóis. Felipe II considera que os jerônimos portugueses tinham se distanciado muito da ordem espanhola, por isso intentava fundir os dois ramos peninsulares. No capítulo geral de 1591, o vicerei de Portugal, cardeal-arquiduque e sobrinho do rei, começou a preparar a unificação dos dois ramos da Ordem de São Jerônimo, fazendo visitas aos monastérios jerônimos portugueses. Foram nomeados espanhóis como priores de

\footnotetext{
259 FERNANDEZ SEVILLA, J. C. Op. Cit.p.17

${ }^{260}$ Ibidem.

${ }^{261}$ Ibidem.
} 
alguns conventos, sendo que os portugueses insistiram que não se fizesse o mesmo no caso de Belém, o que foi aceito. A união desses religiosos foi também aceita pelo papa. A partir do capítulo geral de 1597, passaram a constituir uma única ordem religiosa e os monges portugueses começaram a participar das celebrações capitulares.

Ainda que hoje possamos ver o Monastério do Escorial como uma verdadeira obra de arte, que se manteve admirável ao longo do tempo, não devemos pensar no edifício apenas como uma obra grandiosa por seu estilo e pelas técnicas construtivas empregadas para sua execução. Essa edificação tinha como preocupação ser adequado ao papel que desempenharia, ou seja, estar em decoro. Num período e num contexto em que o poder do monarca espanhol estava intimamente ligado ao comprometimento e à defesa da fé católica, a tipologia do edifício a ser erguido como símbolo e memória de um período estava completamente relacionada à própria concepção de poder do monarca.

Como apontam Nieto Alcaide ${ }^{262}$ e Checa Cremades ${ }^{263}$, os palácios-monastérios eram construções comuns em Castela, desde o reinado de Isabel, a Católica ${ }^{264}$. Nesse sentido, o testemunho do frei Siguenza deve ser considerado como fundamental para se compreender o papel da Ordem de São Jerônimo nesse projeto de Felipe II.

Sabemos que o monarca por muito tempo não permitiu que se escrevesse uma história "oficial" de seu governo, e que muito do que sabemos foi escrito de um ponto de vista desfavorável à sua imagem, por aqueles que o viam como inimigo ${ }^{265}$. Felipe II apenas mudou de postura ao final de seu reinado, quando

${ }^{262}$ CÁMARA MUÑOZ, A. Arquitectura y Sociedad en el Siglo de Oro. Madrid: Ediciones El Arquero Textos Universitários, 1990.

${ }^{263}$ NIETO ALCAIDE, V. M. e CHECA CREMADES, F. El renacimiento: formación y crisis del modelo clásico. Madrid: Ediciones Istmo, 1993.

${ }^{264}$ NIETO ALCAIDE, V. M. e CHECA CREMADES, F. Op. Cit.

${ }^{265}$ GARCÍA CÁRCEL, R. Felipe /l y los historiadores del siglos XVII. in: BENNASSAR PERILLIER, B.; et. al. Vivir el Siglo de Oro. Poder, Cultura e História en la época moderna. Estudios en homenaje al profesor Ángel Rodríguez Sánchez. Salamanca: Universidad de Salamanca, 2003, pp.285-316. 
a imagem negativa do rei já fora criada pelos escritores de fora da península, buscando, assim, reverter tal situação. No entanto, as fontes nunca são isentas e sempre falam de um lugar definido. Se as fontes mais abundantes se mostram mais "críticas" a esse rei, o que temos, em contrapartida com a escrita da "História primitiva y exacta del monasterio del Escorial”266, pelo padre Siguenza, é o relato de um frei que, ao contar a história da construção do Escorial, coloca o rei como a principal personagem ao lado de sua obra. Esse relato é, ao mesmo tempo, um grande elogio ao rei prudente e uma história da construção material e espiritual do monastério.

O Padre Siguenza nasceu na cidade de Siguenza, Guadalajara, filho de um clérigo, Asensio Martínez, e uma viúva, Francisca Espinosa. Sua carreira religiosa se iniciou em 1556, no Monasterio Del Parral, em Segóvia, que existe até hoje, e continua a abrigar a ordem de São Jerônimo. Tornou-se bacharel em artes pela Universidade de Salamanca e depois ingressou na Ordem dos Jerônimos. Em 1590 transferiu-se definitivamente para monastério do Escorial, onde viveu durante os anos mais decisivos e dramáticos de sua vida junto à coroa. Foi processado pela Inquisição e absolvido, escreveu a História do Escorial, foi elevado a prior duas vezes e faleceu em $1606^{267}$. Foi historiador de Felipe II, hebraísta, bibliotecário da Biblioteca do Escorial. Como apontamos anteriormente, seus escritos também são a principal referência à história desses monges, cuja existência está circunscrita aos limites territoriais da Península Ibérica.

O texto de Siguenza nos mostra a versão sobre a história da construção do Escorial em consonância com a memória que se desejava guardar da monarquia, caso contrário não seria aprovada para a impressão. Dessa forma, encontramos um discurso de dentro da corte, muito próximo ao rei. Segundo o relato de Siguenza, ao decidir edificar um monastério em homenagem à vitória na Batalha

\footnotetext{
${ }^{266}$ SIGÜENZA, Frei J. História primitiva y exacta del monasterio del Escorial. Escrita en el siglo XVI por el Padre Fray José de Sigüenza bibliotecario del Monasterio y Primer Historiador de Felipe II, arreglada por D. Miguel Sánchez y Pinillos. Madrid: Imprenta y Fundacion de M. Tello, Impresor de Câmara de S. M. Isabel la Católica, 23, 1881. Edición Fac-simile. Valladolid: Editorial Maxtor, 2003.

${ }^{267}$ DÍAZ DÍAZ, T. "El entierro de San Lorenzo", posiblemente el mejor cuadro de Juan Fernández de Navarrete "el Mudo" (Padre Sigüenza). In: JAVIER CAMPOS, F. e SEVILLA, F. de (coord..). EI Monasterio del Escorial y la pintura: actas del Simposium, 1/5-IX-2001 / , 2001, ISBN 84-89942-242, págs. 561-580.
} 
de San Quintin, em 10 de agosto, dia de São Lourenzo, esse projeto não poderia estar desvinculado das intenções de se estabelecer um lugar para o rei e sua corte, como fica claro nas palavras de Siguenza:

“Luego [que sucedeu Carlos $V$ como gobernante da Espanha] trato
nuestro Felipe de poner en ejecución sus buenos propósitos;
comenzó primero á poner los ojos dónde asentaría su corte,
entendiendo cuán importante es la quietud del Príncipe, y estar en un
lugar para desde allí proveerlo todo y darle vida, pues es el corazón
del cuerpo grande del reino. Contentóle sobre todo la villa y comarca
de Madrid, por ser el cielo más benigno y más abierto, y porque es
como el medio y centro de España, donde con más comodidad
pueden acudir de todas partes los negociantes de sus reinos y
proveer desde allí á todos ellos; razon es bien miren los reyes, pues
no se hicieron los reinos para ellos, sino para el bien de su reino
$(\ldots)$ ".268

Dessa maneira o local escolhido para o Mosteiro do Escorial, que deveria ser propriamente a morada de São Lourenço, estaria bem situado em uma região afastada, ainda que não muito, de Madrid, para dar tranqüilidade aos monges e ao rei ${ }^{269}$

Outra intenção de Felipe II em construir o Escorial era criar uma morada aos Habsburgos espanhóis após a morte, ser um mausoléu para essa dinastia. Siguenza aponta que o monarca estava preocupado com o local em que seria sepultado definitivamente o corpo do Imperador Carlos V. Para estar de acordo com a dignidade deste homem, deveria ser transferido para o Escorial, onde toda a família real descansaria junta ${ }^{270}$. Dessa forma, o monastério também serviria à perpetuação da memória da monarquia e local adequado para o descanso dos reis.

Como a morada final dos Habsburgos, o Escorial e a Ordem de São Jerônimo formavam um par fundamental para a memória de seus monarcas. $O$ Escorial, edifício que guardaria a memória visível aos vivos da religiosidade e da grandeza do governo dessa dinastia, e os monges em seu interior cumpriam a função de guardar a memória de seus reis junto a Deus, continuando a prática

\footnotetext{
${ }^{268}$ Siguenza, Op. Cit. p. 24

${ }^{269}$ SIGUENZA, F. Op. cit., p.24.

${ }^{270}$ Ibidem, p. 18.
} 
anterior de rezar por suas almas, enquanto seus corpos estavam guardados e protegidos em um espaço sagrado. Nas palavras de Paolo Rossi:

"as cerimônias em memória dos mortos (...) não testemunham só a dor individual e a vontade de não esquecer: o sacrifício monástico da intercessão não ergue ao falecido um monumento sobre a terra, mas, 'inserindo o seu nome na lista a ser lida durante a liturgia, efetua 0 seu acolhimento na Liber vitae celeste, na memória eterna de Deus. ${ }^{, 271, "}$

Ou seja, entre tantas funções que podem ser atribuídas à Ordem dos Jerônimos como escolhidos para habitar o Escorial, rezar pelas almas dos reis ali sepultados, naquele momento, estava entre de maior importância.

Para escolher o local apropriado para essa obra, o rei pede opinião a filósofos, médicos e arquitetos. Siguenza segue com uma descrição detalhada da vila do Escorial, justificando a escolha do local por sua superfície plana de extensão suficiente para receber uma edificação de "grande porte"272. Além disso, as condições climáticas e os ventos da região eram adequados aos desejos do rei.

Uma das principais preocupações de Siguenza em toda a sua obra é marcar, em todos os aspectos de sua história do Escorial, a participação dos monges nessa edificação, que compreende um aspecto fundamental para dar o caráter de um templo santo ao Monastério. Em 1561 são nomeados os religiosos que estariam à frente do Escorial, o primeiro prelado e fundador do Monastério Frei Juan de Huete (prior de Zamora) e o vigário Frei Juan de Colmenar (de San Jerónimo de Guisando) ${ }^{273}$.

Juntamente com os religiosos, os leigos diretamente ligados à obra também vão para Guadarrama, a pedido do rei, para ver o terreno em que se deveria construir o monastério: secretário Pedro de Hoyo e Juan Bautista de Toledo.

\footnotetext{
${ }^{271}$ Rossi, P. O passado, a memória, o esquecimento. Seis ensaios da história das ideias. São Paulo: Editora Unesp, 2007, p.24

${ }^{272}$ SIGUENZA, J. Op. cit., p.26.

${ }^{273}$ Ibidem, p. 31.
} 
Ao longo de sua história, Siguenza sempre elogia este arquiteto, chamando-o de "varon de gran juicio y excelente maestro en arquitectura". ${ }^{274}$

Simultaneamente se inicia a obra em seus aspectos arquitetônicos (com os desenhos de Juan Bautista), espiritualmente (com a chegada de mais religiosos para servir no local), e também se iniciam os jardins.

A idéia de se construir um edifício real e sagrado, como uma mostra da estreita ligação entre a monarquia e a fé cristã com centro em Roma, é a marca do discurso da história escrita pelo padre Siguenza. A grandiosidade do reino e a grandiosidade do cristianismo defendido por seus reis estão conjuntamente expressas no monastério do Escorial, o que está claramente posto nesse documento que nos foi deixado. Dessa forma, o número de religiosos que viveriam no monastério foi dobrado em relação ao projeto inicial, pois, segundo Siguenza:

"Parecióle depues al Rey que no igualaba esta traza á sus deseos, que era cosa ordinaria un convento de San Jerónimo de cincuenta religiosos, y que conforme sus intentos y la majestad del oficio divino que pretendía resplandeciese aquí, y para las memorias que se habían de hacer por sus padres, era pequeño número, acordó que fuesen los religiosos ciento, y el convento fuese el más ilustre que hubiese en España, no solo de religiosos de San Jerónimo, sino de las Órdenes Monacales; pidió parecer á algunos maestros de arquitectura sobre cómo se podía hacer esto; unos decían que se mudase la planta, otros que se hiciesen nuevos claustros, y otros daban otras trazas." 275

A solução para adequar a planta traçada à nova exigência prática do projeto foi do Frei Antonio de Villacastin, que sugeriu que se levantasse o edifício sem alterar a planta ${ }^{276}$.

A sacralidade do edifício construído por Felipe II estava também relacionada à presença de uma grande coleção de relíquias acumuladas pelo

\footnotetext{
${ }^{274}$ Ibidem, p.34.

${ }^{275}$ Ibdem, p.55.

${ }^{276}$ Ibidem, p. 56.
} 
monarca no mosteiro do Escorial. ${ }^{277}$ As relíquias eram partes dos restos mortais de santos, principalmente de mártires. Em geral os ossos, cabelos, unhas, sangue, poderiam ser considerados como restos sagrados desses homens, ou mesmo fragmentos de objetos pelos quais foram martirizados. Considerava-se que em cada uma dessas partes estava contida a integralidade do santo, sendo que a própria capacidade de se multiplicar em relíquias que realizavam milagres, constituía-se como uma das provas dos poderes do santo ${ }^{278}$. Como coloca Renato Cymbalista:

"As curas, as emanações maravilhosas, os traslados milagrosos, a incorruptibilidade eram as provas de que os santos estavam privando da companhia de Cristo, de que suas relíquias eram artefatos divinos que rompiam as barreiras do tempo e do espaço."279

No século $\mathrm{XVI}$ as relíquias continuaram a conter em si a capacidade de proteger edifício e cidades, promover curas, sacralizar altares... No entanto, esse aspecto do cristianismo de até então foi um dos alvos das idéias dos reformadores, como Lutero, que se escandalizava com o número de relíquias em Wittemberg.

O Concílio de Trento teve a postura oposta aos reformadores no que diz respeito às relíquias. Reforçou a crença no poder milagroso dos corpos dos santos, reafirmando sua presença física e integral até mesmo no menor fragmento, em oposição ao desejo de se construir uma religiosidade sem a intermediação por objetos proposta por Martinho Lutero. A veneração das relíquias se intensificou nos países católicos. Muitos corpos atribuídos a santos foram encontrados, nesse contexto, e geraram um maior número de relíquias ${ }^{280}$.

Felipe II se esforçava em conseguir relíquias, inclusive mandando trazer do Sacro Império as relíquias das Igrejas que desejassem enviá-las à

277 BOUZA ÁLVARES, J. L. Religiosidad contrarreformista y cultura simbólica del barroco. Madrid: Consejo Superior de Investigaciones Científicas, 1990.

${ }^{278}$ CYMBALISTA, R. Relíquias sagradas e a construção do território cristão na ldade Moderna. In: Anais do Museu Paulista. Vol. 14. São Paulo: Universidade de São Paulo, 2006, pp.11-50.

279 Ibdem, p.14-15.

${ }^{280}$ BOUZA ÁLVARES, J. L. Religiosidad contrarreformista y cultura simbólica del Barroco. Madrid: Consejo Superior de Investigaciones Científicas, 1990. 
Espanha, pois considerava que nesse território em que a reforma de Lutero tinha conquistado muitos fiéis suas relíquias corriam perigo de destruição. O monarca enviou vários agentes nomeados para buscar essas relíquias em locais que aderiram à reforma. Escreve Siguenza:

"Porque de todo punto quedase colmado este único santuario y gloria de la piedad de Felipe II, con los tesoros y riquezas del cielo, con sumo secreto y de años atrás había el prudentísimo Monarca alcanzado licencia, privilegios y breves de los Sumos Pontífices, para sacar por las más lícitas y santas maneras que pudiese, de toda Alemania, reliquias de todos los santos de cualquier iglesia ó monasterio que quisieren conceder á sus peticiones, y de cualquier tamaño ó grandeza, aunque fuesen cuerpos enteros de santos. Habidas estas licencias, y ofreciéndoseles ministros que supiesen ejecutar sus devotos deseos, sin perdonar ningún género de costa ni de interés, se allegaron en diversas iglesias, monasterios y conventos de Alemania, gran suma y tesoro de ellas, gratificando á los interesados con larga mano."

Dessa maneira, as relíquias como elementos de sacralização dos espaços são lembradas na História da construção do escorial, sobretudo com ênfase nas relíquias de São Lourenço e do príncipe mártir da Espanha, Hermenegildo:

"Se trajeron algunas joyas para el servicio del altar y sacristia, y muy preciosas reliquias, entre ellas, un hueso del anca del glorioso mártir Lorenzo, su patrón y abogado, con éstas, vino otra de inestimable precio, la cabeza del gloriosísimo Príncipe mártir Hermenegildo de España, y otras más particular."281

Colocar a ênfase nesses dois santos significa, também, chamar a atenção para os santos de origem hispânica. As relíquias desses santos se destinavam "al servicio del altar e sacristia", ou seja, locais de enorme importância dentro da hierarquia dos espaços sagrados de uma igreja, onde se encontravam os religiosos no momento dos rituais de consagração da comunhão, por exemplo.

A consagração do edifício é um dos aspectos mais importantes, dentro do discurso de Siguenza, para a edificação espiritual do Monastério. No relato, se considera que a consagração do templo era uma prática já em desuso na Espanha:

${ }^{281}$ Siguenza, Op. Cit., p.147-8. 
"Así queda esta fábrica de todo punto perfecta en lo de las partes de dentro y fuera. Resta digamos otras dos importantísimas: la consagración de este templo, cosa digna de consideración por ser ya esta ceremonia y sacramento tan desusado en España; el feliz tránsito de nuestro fundador, que cada una merecía un libro entero." ${ }^{282}$

Claramente, há a valorização do reinado de Felipe II em seu papel como defensor da fé cristã de Roma, inclusive retomando práticas anteriores. Essa valorização se dá tanto em relação aos outros monarcas europeus, quanto aos seus antecessores. Tal discurso pode ser percebido no trecho a seguir:

"En este santo y consagrado templo, hay cuarenta altares consagrados (...)En cada uno de, están puestas en la cueva ó sepulcro que se hace en medio de la mesa, muchas reliquias de santos, y creo que desde el principio de la Iglesia hasta hoy, no se ha visto templo donde haya cosa semejante: memoria digna de la insigne piedad de Felipe II y digna basílica y casa Real del gran mártir Lorenzo (...)"283

Depois de tratar brevemente da edificação, de dar destaque para a participação dos monges jerônimos na construção de um edifício com caráter sagrado, de valorizar a consagração do templo, sobretudo com as relíquias que para esse local foram levadas, Siguenza se ocupa em descrever os últimos momentos do monarca Felipe II para finalizar a primeira parte, de duas, de seu relato sobre a construção do monastério do Escorial. Aparentemente este relato destoaria do restante da obra ${ }^{284}$.

A maneira como Felipe II encara a morte, no relato deixado pelo frei, demonstra como o rei poderia ser tomado como exemplo de cristão, e como sua

\footnotetext{
${ }^{282}$ Ibdem., p. 176.

${ }^{283}$ Ibdem., p.193.

${ }^{284}$ Os discursos são assim organizados:
}

Discurso XX - La última enfermedad y feliz muerte del Rey Don Felipe II, fundador de este convento, con otros particulares que tocan á su fundación

Discurso XXI - Se sigue el tránsito y muerte del Rey Don Felipe II, las preparaciones de su muerte, su entierro, el codicilo último para las cosas de esta casa

Discurso XXII - El entierro y exequias del Rey Don Felipe II en esta su casa y sepulcro. Lo que dejó mandado para su sustento en su último codicilio 
postura como defensor da fé em toda vida não era contrariada nem ao menos nesse último momento:

"Como en todo lo fue tan Rey y tan alto ánimo este gran Príncipe, parece que aún quiso reinar y enseñorearse sobre la muerte. La estaba aguardando y tratando de sus cosas con tanta igualdad de ánimo lo que á otros atemoriza, que dijera el que le veía, no era él el que estaba tan al cabo, sin negocio de otro."285

"Quiso tambien, como prudente y católico Príncipe, hacer uma protestacion de a fe y de cómo moria en la obediencia de la Santa Iglesia Romana y del Sumo Pontífice, Obispos, Sacerdotes y Ministros de ella"286

Além da morte de Felipe II, que o coloca como um exemplo de governante cristão, a comparação entre esse rei e Salomão, e entre o Escorial e o templo antigo de Jerusalém também compõe a construção dessa imagem elogiosa por Siguenza. O frei coloca:

“(...)la maneira de fabricar esta iglesia y labor de ella imitó mucho á la del mismo Salomon, la traza e ingenio fué, que la piedra toda se labrase en las canteras, de suerte que, al pie de la obra, ni en el templo, apenas se oyese el golpe del pico ni martillo (...)"287

Esse discurso também é apresentado na obra de Villapando, "In Ezechielem explanationes et apparatus urbus ac templi hierosolymitani" (Roma, 1596-1605). As duas obras são praticamente escritas simultaneamente, o que é analisado por René Taylor ${ }^{288}$ para compreender a contrução da imagem de Felipe II como segundo Salomão. O que devemos acentuar aqui é que essa imagem foi bastante difundida nos anos finais do século XVI e no século XVII, o que compôs um dos elementos a serviço de uma imagem positiva de Felipe II.

O padre Siguenza se ocupa em comparar as vitórias alcançadas por Felipe II com as de algumas personagens bíblicas que defenderam militarmente seu povo, como Josafat, Judas Macabeo, Betulia, etc. O padre justifica essa

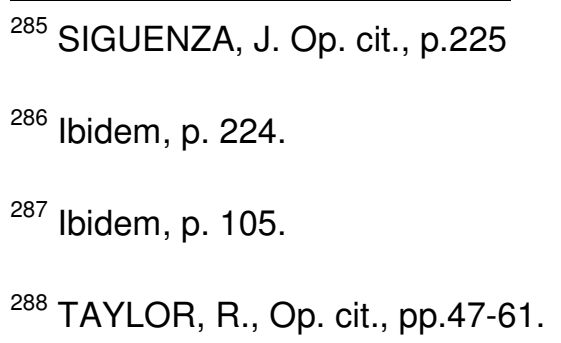


escolha, dizendo que para se voltar ao passado e aos seus exemplos, "no tenemos que buscar ejemplos profanos, pues nos lo da á la mano la Santa Escritura"289

Essa retomada dos símbolos reais do Antigo Testamento, como também considera Fernando Checa ${ }^{290}$, é uma maneira de valorização de uma antiguidade não pagã e imediatamente anterior ao cristianismo, sendo uma espécie de "cristianização da antiguidade", compatibilizando a retomada de um passado clássico renascentista com os ideais de enaltecimento do cristianismo, agora como catolicismo tridentino.

Essa concepção poderia também ser estendida ao apelo a Raimundo Lullio nos escritos de Juan de Herrera sobre geometria ${ }^{291}$, ao lado das concepções euclidianas. Além do caráter hermético desses escritos, Herrera coloca o pensamento de Lullio como central em sua obra, enquanto Euclides apenas é utilizado como um meio para possibilitar o entendimento do pensador medieval catalão. Como nos fala Fernando Checa: "No es ahora Platón, sino la tradición cristiana de Raimundo Lulio la que le sirve de apoyo: el cubo resulta ser la figura geométrica perfecta."292 É fortalecida a união entre o passado clássico e o passado cristão. Assim Fernando Checa sintetiza:

"La armonía proporcional del edifício se conviene en un sistema de correspondencias, fundada en una revisión de las categorias pitagóricas, vistas desde la óptica del clasicismo vitruviano, y pasada por el tamiz platonizante y cristiano de San Agustín y el mágico de Raimundo Lulio; son estas las bases del clasiscismo de Juan de Herrera, (...)"293

Herrera, nessas bases, propõe um novo classicismo caracterizado pela desornamentação e valorização das formas geométricas, o que aproxima a

\footnotetext{
${ }^{289}$ SIGUENZA,J. Op. cit., p.15.

${ }^{290}$ NIETO ALCAIDE, V. M.; MORALES, A. e CHECA, F. Op. cit.

${ }^{291}$ HERRERA, J. Discurso sobre la figura cubica [s.d.]. Santander: Biblioteca Menendez Pelayo, [s.d]. Disponível em: http://www.bibliotecademenendezpelayo.org/Visor.aspx?op=6\&Admin=TRUE\&IdLibro=1\&codigo=M72 . Acesso em 22 de novembro de 2006.

${ }^{292}$ NIETO ALCAIDE, V. M.; MORALES, A. e CHECA, F. Op. cit., p.323.

${ }^{293}$ Ibdem, p.312
} 
arquitetura da engenharia militar, dando ao edifício do Escorial a idéia de uma fortaleza. E vale lembrar que Raimundo Lullio, além da sua vasta e diversa obra escrita, teve um grande papel em sua vida como defensor da fé cristã, conhecendo o pensamento islâmico para poder melhor formular sua tentativa de conversão dos muçulmanos. Acabou a vida como mártir.

Continuando nesse mesmo sentido de valorização da religião cristã e seus aspectos, trataremos a seguir do poema de Luis Cabrera de Córdoba (1559-1623), "Laurentina". 


\subsection{Portugal e Espanha: União Política e na Fé}

Luis Cabrera de Córdoba, o autor do poema também estudado como fonte em nossa pesquisa, Laurentina, é mais conhecido como historiador. Proveniente de uma família nobre, descendente em linha direta dos condes de Torres Cabrera, nasceu em Madrid, em 1559. Sua família se dedicava à carreira das armas, o que também seguiria. Em 1584 vivia em Nápoles, com o Duque de Osuna, e apenas voltou à Espanha para dar notícias ao rei sobre um tumúltuo que ocorrera em Nápoles em 1585, ocasião em que se deu a sua visita ao Escorial. Foi uma espécie de embaixador de Felipe II, e destes serviços ao monarca pôde acumular uma infinidade de anotações sobre o funcionamento desse reinado.

Foi escrita por Cabrera de Córdoba a primeira "vida" de Felipe II, a qual nos referimos anteriormente, e que, não coincidentemente, tinha como imagem estampada em sua capa a alegoria de Felipe II como defensor da Igreja, com o Escorial ao fundo. Essa obra foi finalizada em 1583 e impressa em 1619. O historiador também compôs as obras "Relaciones de las cosas sucedidas, principalmente en la corte, desde el año 1599 hasta 1614", e "Historia para entenderla y escribirla", entre outras.

Como autor culto, Cabrera escolheu o título de seu poema com evocação clássica: Laurentina, canto a San Laurencio. O texto é dedicado ao vicerei de Portugal Cardeal Alberto, mas não sabemos os motivos que levaram o autor a essa dedicatória, nem se tem alguma relação com as menções feitas pelo autor a acontecimentos do reino de Portugal. Segundo Bouza ${ }^{294}$, havia um papel destacado na atitude de dedicar uma obra, com a intenção de patrocínio para a impressão da

\footnotetext{
${ }^{294}$ BOUZA ÁLVAREZ, F. Escribir en la corte. La cultura de la nobleza cortezana y las formas de comunicación en el Siglo de Oro. in: BENNASSAR PERILLIER, B/; et. al. Vivir el Siglo de Oro. Poder, Cultura e História en la época moderna. Salamanca: Universidad de Salamanca, 2003, pp.77100.
} 
mesma, ou um benefício. Não há informações sobre isso na edição realizada sob os cuidados de Lucrecio Perez Blanco ${ }^{295}$.

Apenas estão conservados os cantos primeiro, vigésimo terceiro, vigésimo quarto, vigésimo quinto, vigésimo sexto, vigésimo sétimo e vigésimo oitavo. Apesar disso, podemos ter alguma ideia sobre o projeto pelo que o escritor explicita no prólogo. Na descrição inicial do poema, o autor dá grande ênfase à questão da incorporação de Portugal pela Monarquia Hispânica, como se pode perceber em suas palavras: "El rio Tajo, viendo que V. M. goza ya todo lo que él baña, por ser cosa que él en extremo deseaba, determina de hacer una fiesta y tirunfo para celebrar estos felices sucesos." 296

Ainda no prólogo, Cabrera se detém na fundação de Lisboa, na sucessão dos reis portugueses e a prematura morte de Dom Sebastião. Também menciona as ordens militares de Alcântara, Calatrava e Santiago. Faz referência ainda aos primeiros reis povoadores da Espanha, desde Ataulfo até Rodrigo, último dos Godos, e desde Pelayo até os dias do reinado de Felipe II. Também canta a entrada de Felipe II em Portugal, depois da vitória do rei contra Filipo Stroci, para só então começar a descrição do Escorial. Essa descrição não pretende se figurar com caráter técnico de arquiteto, mas como poeta.

Mesmo tendo sido iniciado antes da União das Coroas Ibéricas, o Escorial, em sua simbologia, pode ter incorporado também a idéia da união de reinos cristãos peninsulares. Também, como considera Bouza Álvares ${ }^{297}$, Portugal é incorporado à Monarquia Hispânica por Felipe II quando esse não se encontrava no melhor momento de seu reinado. Após a Batalha de Lepanto, no início da década de oitenta do século XVI, os turcos já se mostravam recuperados e um inimigo que não devia ser ignorado, além das inúmeras rebeliões dos neerlandeses que deveriam ser

${ }^{295}$ CABRERA DE CORDOBA, L. (c.1590). Laurentina. Edição de Lucrecia Perez Blanco. Madrid: Villena, 1975.

296 Ibidem, p.23.

297 BOUZA ÁLVARES, F. Introdução. In: idem (organização, introdução e notas). Carta para duas infantas meninas. Portugal na correspondência de D. Felipe I para suas filhas (1581-1583). Trad. Nuno Senos. Lisboa: Dom Quixote; Comissão Nacional para as comemorações dos Descobrimentos Portugueses, 1998. 
enfrentadas. Dessa forma, e a incorporação do reino vizinho, unificando a administração da Península Ibérica, mostrava-se como uma grande possibilidade de enfrentar os desafios do monarca Habsburgo, o que valoriza ainda mais essa união.

O símbolo do catolicismo expresso no Escorial era carregado de elementos que fortaleciam a imagem do cristianismo na península lbérica: São Lourenço era um mártir espanhol e a Ordem dos Jerônimos era exclusivamente ibérica, justamente os monges que guardariam as sepulturas dos reis Habusburgos que governaram toda a península.

Mesmo declarando que não sabia exatamente os motivos que levaram Felipe II a construir esse monastério, Cabrera coloca explicitamente:

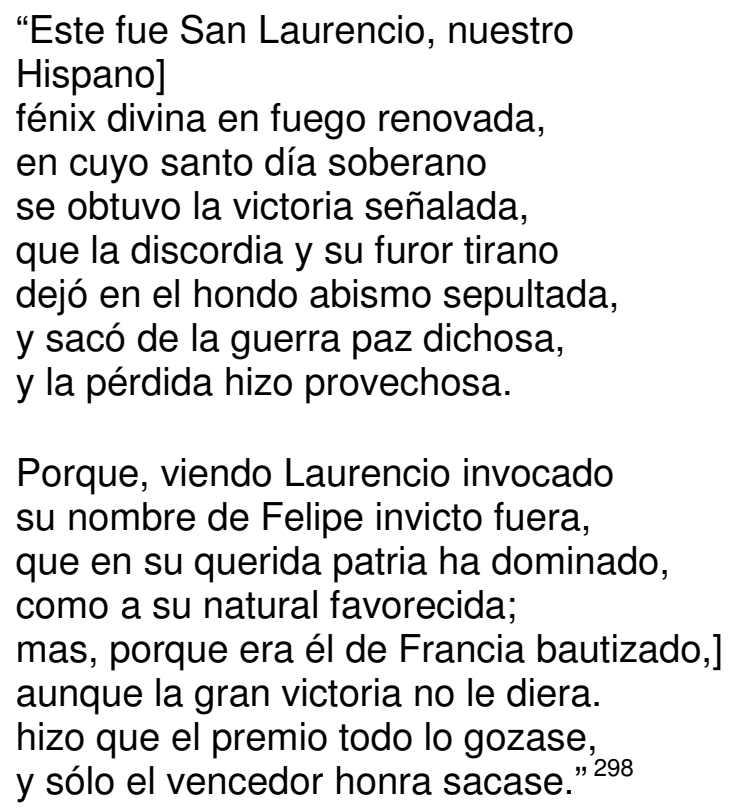

Vale comparar com o elogio de frei José de Siguenza sobre a Batalha de San Quintin:

"Fue ésta la primera de las victorias que tuvo Felipe II, y acerto por celestial acuerdo a ser en 10 dias de Agosto, fiesta del glorioso mártir San Lorenzo, español, á quien su niñez tuvo este piadoso Príncipe singular devoción: entendió que un principio tan ilustre de sus cosas le venia por su favor e intercesiones en el cielo, y así, desde aquel punto, concibió en su pecho un alto propósito de hacerle algun señalado servicio."299

\footnotetext{
${ }^{298}$ Ibdem, p.119.

${ }^{299}$ SIGÜENZA, Frei J. Op. cit., p.13.
} 
Os dois trechos se constroem com base em argumentos muito semelhantes. Cabrera continua seu poema deixando explicito o discurso de defesa do cristianismo contra a heresia nas ações de Felipe II:

\author{
"Todos, en general, septentrionales \\ están de la herejía enamorados. \\ como los de las partes orientales \\ en su anchura vida muy cebados. \\ Siguen la misma los meridionales \\ como bárbaros, brutos, ya privados \\ del uso racional, con muchos vicios, \\ hacen a su Mahoma sacrificios. \\ Italia ha mucho tiempo que floresce \\ en santidad y fe que ha conservado \\ y, como nuestra España, resplandece \\ con el favor que le ha comunicado; \\ que aquí se cria, aquí se aumenta y crece] \\ en el regazo dulce y regalado \\ de los censores santos, que la amparan] \\ y de sua enemigos la reparan.
}

Privaros, luteranos infernales, turcos bárbaros, escitas inhumanos, de gozar los secretos celestiales que comunica Dios a sus cristianos, que vuestras sectas son irracionales, llenas de ceremonias, ritos vanos, y no gozáis jamás de los oficios, que la Iglesia hace a Dios y sacrificios.] $]^{300}$

Em todo o poema, essa defesa da fé católica parece estar mais destacada no seguinte trecho:
"Si entrásedes em este templo santo, que por el gran Felipe se há fundado, amor os causaría y grande espanto, el verle de mil joyas adornado y más su celestial y sacro canto con que el Senñor del Cielo es alabado,] y sus misterios grandes celestiales, y de todos su santos inmortales. ${ }^{301}$

\footnotetext{
${ }^{300}$ CABRERA DE CORDOBA, L. Op. cit., p.129.

${ }^{301}$ Ibdem, p. 129.
} 
Cabrera deixa explícito o quanto aquele "templo santo" do Escorial era um símbolo que qualquer protestante ou infiel que pudesse ter o privilégio de adentrar perceberia sua riqueza, grandiosidade e o quanto toda aquela opulência era coerente com a riqueza daquela fé, quase como um sinal afirmativo da fé verdadeira. Já havíamos apontado a mesma preocupação expressa por Felipe II às suas filhas, de que o Escorial fosse visto, que pudesse realmente ser a imagem de sua religiosidade àqueles de outros reinos que visitavam a Espanha ${ }^{302}$.

Ainda nesse sentido da valorização do Escorial como símbolo da religiosidade de Felipe II, expressa na obra de Siguenza e Cabrera de Córdoba, podemos pensar nas construções espanholas do século XVI também através de um termo bastante retomado no período nos círculos artísticos europeus: o decoro.

Em termos gerais, o decoro, retomado pelos artistas italianos renascentistas dos textos antigos, refere-se à adequação, à conformidade do objeto de arte criado em diferentes segmentos artísticos, às funções que deve desempenhar, à mensagem a ser transmitida e ao público a que se dirige. No caso dos edifícios, o decoro significa que a construção deve se adequar à sua função. $\mathrm{Na}$ pintura, como escreve Francisco de Holanda, se pretende a conformidade entre o sentimento da imagem central de uma pintura e o que se encontra ao seu redor. Nesse sentido, o decoro é, antes de tudo, uma concepção puramente estética. Esse sentido iria sendo pouco a pouco modificado ao longo do século XVI e ganhando um caráter mais ligado à moralidade, sobretudo a partir da crítica da obra "Juízo Final", de Michelângelo, devido às imagens desnudas pintadas pelo artista ${ }^{303}$.

O decoro também aparece ao longo do texto do Padre Siguenza sobre a construção do Monastério do Escorial, no entanto, com seu sentido um pouco diferente do uso dado pelos tratadistas italianos no século $\mathrm{XV}$, mas ainda não completamente ligado à nova acepção moralista adquirida no século XVI. Para

\footnotetext{
${ }^{302}$ BOUZA ÁLVARES, F. J. (org., introd. e notas). Cartas para duas infantas meninas: Portugal na Correspondência de Filipe I para suas Filhas (1581-1583). Lisboa: Dom Quixote; Comissão Nacional para as comemorações dos Descobrimentos Portugueses,1998, p. 129.

303 MARTíNEZ-BURGO GARCÍA, P. El decoro. La invención de um concepto y su proyeccción artística. In: Revista de La Facultad de Geografia e Historia, num. 2, 1988, págs. 91-102.
} 
Palma Martínez-Burgo ${ }^{304}$, quando o padre Jerônimo utiliza esse termo em seus escritos, sua concepção guarda o sentido de conveniência, considerando as pinturas profanas presentes na decoração da biblioteca do Escorial em conformidade com o esse espaço. No entanto, ao tratar das imagens religiosas, considera que muitos artistas descuidam do decoro ao utilizar imagens sensuais ou desnudas: "Los pintores de Italia, aún los muy prudentes no han tenido tanta atención al decoro como a mostrar la valentia de su dibujo, y asi han hecho cosas de santos que quitan la gana de rezar en ellas". 305

A postura dos financiadores de obras artísticas na passagem do século XVI para o século XVII, com as repercussões da reforma protestante no norte da Europa e as formulações do Concílio de Trento, ganha na Espanha um claro objetivo de demonstrar a defesa da fé católica e, principalmente, através da figura do rei como principal agente dessa defesa. Tal idéia de unidade, em muitos casos, expressava-se do maior controle possível dessa simbologia pela coroa.

Durante o reinado do imperador Carlos V, os baluartes recebiam nomes como "baluarte del gobernador", ou "cubo de Leiva"; mas no reinado de seu filho esse costume quase desaparecerá, pois as fortalezas também ganham uma concepção proveniente da mentalidade contra-reformista da monarquia. Assim, vão se repetir os nomes de São Felipe (o santo do rei) e, sobretudo os nomes dos santos que foram militares (São Sebastião, São Jorge, São Lázaro...), ou de santos cuja fortaleza se manifestou ante o martírio (São João e Santo André), ou de santos valorosos na luta contra os demônios (Santo Antonio), ou ainda do santo patrono da Espanha (Santiago) e também de santas, virgens e fortes ante o martírio (Santa Lúcia, Santa Bárbara, Santa Catarina).

Tudo isso demonstra a importância para a coroa dessa mensagem contra-reformista da fé católica ${ }^{306}$, seja como elemento para

304 Ibidem.

${ }^{305}$ SIGÜENZA, Frei J. Op. cit., p.381.

${ }^{306}$ CAMARA MUÑHOZ, A. La fortificación de la monarquía hispanica. In: Espacio, Tiempo y Forma, Serie VII, H. del Arte, t. 2, 1989, págs. 73-80. 
fortalecimento de seu próprio poder ligado a sua condição de defensora da fé, seja como forma de afirmar na religião católica o elemento de unidade dentre os tão diversos territórios que compunham a monarquia hispânica.

A autora também coloca que mesmo com essa tendência, ainda se conservava parcialmente o costume de dar o nome do engenheiro ao baluarte, ou os nomes dos grandes generais, que permaneciam unidos às fortificações através de escudos e inscrições. 
CONCLUSÃO 
Nessas páginas procuramos demonstrar como a arquitetura foi fundamental na monarquia de Felipe II, o que permitiu que o nome de Juan de Herrera se tornasse também conhecido por suas contribuições à coroa.

No primeiro capítulo apresentamos a trajetória de Juan de Herrera como arquiteto e consideramos algumas interpretações historiograficas sobre essa personagem. Dessa maneira, discutimos as particularidades da carreira desse homem. Em primeiro lugar, como um nobre que conseguiu garantir privilégios e uma posição influente junto ao rei, devido aos seus serviços como arquiteto. Também como um homem versado nos conhecimentos matemáticos e envolvido com humanistas e engenheiros, como Honorato Juan e Juanelo Turriano. A possibilidade de ascensão através da atuação como tracista de edifícios reais, e as inúmeras atividades em que aparece servindo à coroa, nos revelam que a arquitetura ganhava um lugar de destaque nas preocupações do reino e a figura do arquiteto ganhava maior prestígio. Toda a carreira de Herrera se deu ligada à monarquia, atento aos desejos do rei na construção de seus edifícios.

No segundo capítulo, demonstramos como Felipe II utilizou-se da arquitetura para reformular espaços urbanos, colocando ali elementos que representassem o seu poder. Nesse aspecto, a participação de Herrera se fez presente como um arquiteto formado dentro do território ibérico, atento às discussões teóricas favorecidas pela circulação de livros e pela presença de humanistas na corte. As obras nas cidades destacavam a imagem da monarquia em relação à imagem dos diferentes poderes que ali se expressavam (palácios da nobreza, as Igrejas de influentes religiosos, os espaços dos mercadores, etc.).

Ainda no segundo capítulo apontamos a participação de Herrera, com papel destacado, na política régia de incentivo às "ciências". O auge dessa atuação se deu ao conseguir influenciar na criação da Academia de Matemáticas, instituição que usufruiu da contribuição de matemáticos, cosmógrafos e astrônomos portugueses que se dirigiram a Madrid para serem professores dessa escola. Herrera foi diretor dessa instituição. Sua formação como arquiteto oferecia a base 
teórica para que pudesse desempenhar as atividades relacionadas a esse cargo, e incentivar a produção de textos e traduções de obras clássicas pelos professores que ali atuavam.

Devido à própria estrutura da Monarquia Hispânica, em que o rei governava diversos territórios, mas preservando suas diferenças, as iniciativas régias na arquitetura, e no incentivo aos estudos matemáticos, demonstram tentativas da monarquia centralizar e controlar certos aspectos de seu governo, e uma maneira do poder real fazer-se presente nesses territórios. Também, devemos lembrar que a Academia levou colaboradores portugueses para Madrid e estabeleceu que suas aulas fossem em castelhano, para facilitar o acesso aos que não sabiam latim. O local e a língua revelam que, nesse esforço, Castela se mostrava como centro promotor da aproximação dos reinos.

Por fim, o terceiro capítulo trata de uma questão que já está posta desde a introdução, e que foi apresentada de diferentes formas nos dois capítulos anteriores: a importância da arquitetura realizada por Herrera para Felipe II como representação do poder real. O Monastério de San Lorenzo el Real del Escorial tornou-se, nesse aspecto, o principal símbolo dessa monarquia. Ali estava representada a imagem de Felipe II, como defensor da Igreja Católica.

O Escorial, como um edifício grandioso, deixava visível a grandiosidade do monarca que o construíu, e de sua família, cujos corpos ali foram sepultados. A sobriedade notável em seus poucos ornamentos refletia a sobriedade da monarquia. Os monges que ali habitavam demonstravam a escolha do monarca por privilegiar uma ordem exclusivamente ibérica, chamando a atenção para o papel de seus reinos na defesa do cristianismo.

A memória que permaneceu desse edifício, através dos historiadores de Felipe II da passagem do século XVI para o XVII, perpetuou a imagem de um monarca católico defensor da Igreja no contexto da Reforma Protestante. Os discursos dos historiadores Jose Siguenza e Luis Cabrera de Córdoba colocam a grandiosidade do Monastério do Escorial como mostra da força de Felipe II contra as heresias. Os sucessos alcançados pelo monarca em seu reinado eram a demonstração de que Deus, e os santos que cultuava, o fortaleciam. 
As duas obras valorizam os reinos ibéricos de Felipe II. Os dois autores chamam à atenção o fato de São Lourenço, homenageado pelo monarca na construção do Monastério, ser um mártir espanhol.

Nesses aspectos Herrera, como arquiteto do rei, foi um dos colaboradores mais próximos do monarca para transformar a arquitetura num recurso de defesa da sua imagem como rei cristão, que unia sob seu poder toda a Península lbérica, valorizando os elementos de identificação entre seus territórios, nesse sentido, aproximando-se ainda mais da Ordem de São Jerônimo.

Tal construção da imagem do reinado de Felipe II era visível aos seus contemporâneos e que foi perpetuado pela memória escrita pelos historiadores José de Siguenza e Luis Cabrera de Córdoba e o próprio edifício do Monastério de San Lorenzo el Real del Escorial em si, ainda hoje símbolo da grandiosidade dos domínios hispânicos da monarquia filipina e das realizações arquitetônicas de Juan de Herrera. 


\section{REFERÊNCIAS}

Fontes manuscritas

HERRERA, J. Discurso sobre la figura cubica [s.d.]. Santander: Biblioteca Menendez Pelayo, [s.d]. Disponível em: http://www.bibliotecademenendezpelayo.org/Visor.aspx?op=6\&Admin=TRUE\&ldLibr $0=1 \&$ codigo=M72. Acesso em 22 de novembro de 2006.

\section{Fontes impressas}

BOUZA ÁlVARES, F. J. (org., introd. e notas). Cartas para duas infantas meninas: Portugal na Correspondência de Filipe I para suas Filhas (1581-1583). Lisboa: Dom Quixote; Comissão Nacional para as comemorações dos Descobrimentos Portugueses, 1998.

- Carta de Tomar, 1 de maio de 1581.

- Carta de Lisboa, 5 de março de 1582.

- Carta de Lisboa, 19 de março de 1582.

- Carta de Lisboa, 16 de abril de 1582.

- Carta de Almeirim, 7 de maio de 1582.

CABRERA DE CORDOBA, L. (c.1590). Laurentina. Edição de Lucrecia Perez Blanco. Madrid: Villena, 1975.

DI TEODORO, F. P. Rafael, Baldessar Castiglione e la lettere a Leone $\mathrm{X}$ sulle rovine di Roma. Bologna: Nuova Alfa, 1996. 
SIGÜENZA, Frei J. História primitiva y exacta del monasterio del Escorial. Escrita en el siglo XVI por el Padre Fray José de Sigüenza bibliotecario del Monasterio y Primer Historiador de Felipe II, arreglada por D. Miguel Sánchez y Pinillos. Madrid: Imprenta y Fundacion de M. Tello, Impresor de Câmara de S. M. Isabel la Católica, 23, 1881. Edición Fac-simile. Valladolid: Editorial Maxtor, 2003.

SIGUENZA, J. Historia de la Ordem de San Jerônimo. Madrid: Casa Editorial Bailly-Ballière, 1902.

Instrucciones de Carlos $V$ a Felipe II sobre política exterior. (Augusta a 18 de enero de 1548). In: FERNÁNDEZ ÁLVAREZ, M. (ed.) Corpus de Carlos V. Salamanca: Universidad de Salamanca, 1975, v. II, pp. 569-592. Disponível em: http://www.cervantesvirtual.com/historia/CarlosV/7 4 testamento.shtml. Acesso em 03 de dezembro de 2008.

Instrucciones de Carlos V a Felipe II (Palamós, 4 de mayo de 1543). in: FERNÁNDEZ ÁLVAREZ, M. Corpus Documental de Carlos V. Salamanca: 1975, t. II, $\quad$ pp. 90-103. Disponível em: http://www.cervantesvirtual.com/historia/CarlosV/7 4 instrucciones.shtml. Acesso em 03 de dezembro de 2008.

Instrucciones secretas de Carlos $V$ a Felipe II. (Palamós, 6 de mayo de 1543) FERNÁNDEZ ÁLVAREZ, M. Corpus Documental de Carlos V. Salamanca: 1975, t. II, $\quad$ pp. 104-118. Disponível em: http://www.cervantesvirtual.com/historia/CarlosV/7 4 instrucciones.shtml. Acesso em 03 de dezembro de 2008.

OLLERO, J. (ed.). Los Austrias. Grabados de La biblioteca Nacional. Madrid: Biblioteca Nacional, 1993.

LLAGUNO, E. Notícias de los arquitectos y arquitectura de España desde su restauración. Madrid: Imprenta Real, reed., 1977, vol.2.

\section{Bibliografia}

ACADEMIA LITERARIA RENASCENTISTA. Nebrija y la introdución del renascimento en España: actas de la III Academia Literaria Renascentista. Salamanca: Ediciones Universidad de Salamanca, 1988.

ALBALADEJO, P. F. Fragmentos de Monarquía. Trabajos de Historia Política. Alianza Editorial, Madrid, 1992. 
ARAMBURU-ZABALA, M. A.(dir.) e GÓMEZ MARTíNEZ, J. Juan de Herrera e su influencia. Actas del simpósio. Camargo, 14/17 julio 1992. Santander: Unversidad de Cantábria/Fundación Obra Pía de Juan de Herrera, 1993.

ARGAN, G. C. Clássico e anticlásico. Trad. Lourenzo Mammi. São Paulo: Cia das Letras, 1999. $\overline{1976,2 v \text {. }}$.

Renascimiento y Barroco. Trad. J. A. Calatrava Escobar. Madrid: Akal,

ARTOLA, M. El Estado. In: idem (dir). Enciclopedia de Historia de España. Vol. II: Instituições Políticas. Império. Madrid: Alianza, 1988, pp. 93-163.

ARTUR, A.P.U. Aportações à Biografia de João Baptista Lavanha. In: Revista da Universidade de Coimbra. Coimbra: Universidade de Coimbra, vol. XXXVI, 1992, pp.395-408.

BATAILLON, M. Erasmo y España. Estúdios sobre la Historia espiritual del siglo XVI. Trad. Antonio Alatorre. México: Fondo de Cultura Económica, 1950.

BARREDO, M.J.R. Madrid, Urbis Regia. La Capital Cerimonial de la Monarquía Católica. Madrid: Marcial Pons, 2000.

BAXANDALL, M. (1972). Olhar renascente. Pintura e experiência social na Itália da Renascença. Trad. Maria Cecília Preto R. Almeida. Rio de Janeiro: Paz e Terra, 1991.

BEBIANO, R. A pena de marte. Escrita da Guerra em Portugal e na Europa (Séculos XVI-XVIII). Coimbra: Edições Minerva Coimbra, 2001.

BENASSAR, M. B. História Moderna. Barcelona: Ariel, 1980.

BENASSAR, B.; VICENT, B. España. Los Siglos de Oro. trad. Teófilo de Lozoya e María Pons Irazábal. Barcelona: Crítica, 2000.

BENNASSAR PERILLIER, B. Los hidalgos em la España de los siglos XVI y XVII: uma categoria social clave. In: BENNASSAR PERILLIER, B.; et. al. Vivir el Siglo de Oro. Poder, Cultura e História en la época moderna. Estudios en homenaje al profesor Ángel Rodríguez Sánchez. Salamanca: Universidad de Salamanca, 2003, pp. 49-61.

BERRIEL, C. E. O. Cidades utópicas do Renascimento. In: Ciência e Cultura. vol.56, nº 2. São Paulo Apr./June 2004, pp.46-48.

BEVAN, B. Estoria de Arquitectura Española. Barcelona: Editorial Juventud, 1950.

BLOCH, M. (1924). Os reis taumaturgos. O caráter sobrenatural do poder régio. França e Inglaterra. Trad. Júlia Mainardi. São Paulo: Companhia das Letras, 2005. 
BONET CORREA, A. Figuras, modelos, e imágenes en los tratadistas españoles. Madrid: Alianza Editorial, c1993. Madrid, 1990.

Fiesta, poder y arquitetctura: aproximaciones al Barroco español. Akal: . El urbanismo en España y Hispanoamerica. Madrid: Cátedra, 1991.

BOUZA ÁLVARES, F. J. Corre manuscrito: una historia cultural del siglo de oro. Madrid: Marcial Pons, 2001.

- Escribir en la corte. La cultura de la nobleza cortezana y las formas de comunicación en el Siglo de Oro. in: BENNASSAR PERILLIER, B.; et. al. Vivir el Siglo de Oro. Poder, Cultura e História en la época moderna. Estudios en homenaje al profesor Ángel Rodríguez Sánchez. Salamanca: Universidad de Salamanca, 2003, pp.77-100.

. La correspondencia del hombre práctico. Los usos epistolares de la nobleza española del Siglo de Oro a través de seis años de cartas del tercer conde de Fernán Núnñez (1679-1684). In: Cuadernos de Historia Moderna. Anejos. 2005, pp.129-154.

Introdução. In: idem (organização, introdução e notas). Carta para duas infantas meninas. Portugal na correspondência de D. Felipe I para suas filhas (1581-1583). Trad. Nuno Senos. Lisboa: Dom Quixote; Comissão Nacional para as comemorações dos Descobrimentos Portugueses, 1998.

Felipe II. Madrid: Akal, 1998.

BOUZA, F. e SANTIAGO, E. Grabar la Historia. Grabar en la Historia. In: OLLERO, Julio (ed.). Los Austrias. Grabados de La biblioteca Nacional. Madrid: Biblioteca Nacional, 1993.

BOUZA ÁLVARES, J. L. Religiosidad contrarreformista y cultura simbólica del barroco. Madrid : Consejo Superior de Investigaciones Científicas, 1990.

BRAUDEL, F. El mediterraneo y el mundo mediterraneo en la época de Felipe II. Trad. Mario Monteforte Toledo e Venceslao Roces. México: Fondo de Cultura Economica, 1987.

BURKE, P. (1992). A fabricação do rei. A construção da imagem pública de Luís XIV. Trad. Maria Luiza X. de A. Borges. São Paulo: Zahar, 2009, 2ª Ed.

O cortesão. In: GARIN, E. O Homem Renascentista. Lisboa: Editorial Presença, 1991, pp.99-120. 
CALVETE DE ESTRELLA, J. C. El felicisimo viaje del muy alto y muy poderoso principe don Phel ippe (Felicíssimo viaje de Felipe ii). Madrid: Museo del Prado, 2001.

CÁMARA MUÑOZ, A. Arquitectura y Sociedad en el Siglo de Oro. Madrid: Ediciones El Arquero Textos Universitários, 1990.

. La fortificación de la monarquía hispanica. In: Espacio, Tiempo y Forma, Serie VII, H. del Arte, t. 2, 1989, págs. 73-80.

CAMÓN AZNAR, J. La arquitectura y la Orfebrería Espanhola del siglo XVI. Madrid: Espasa-Calpe, S.A., 1970.

CAPELATO, M. H. R. A data símbolo de 1898: o impacto da independência de Cuba na Espanha e Hispanoamérica. In: História, vol.22, no.2, Franca, 2003, pp. 35-58.

CASES MARTINEZ, V. La polémica España de Masson de Morvilliers. In: idem (ed.). La España de la Encyclopédie méthodique de 1782. Murcia: Biblioteca Saavedra Farjano, 2010, pp.03-33.

CAVANILLES, A. J. Observaciones sobre el artículo "España” de la Nueva Enciclopedia. Trad. Mariano Rivera. Madrid: Imprenta Real, 1784.

CAVALLIER, M. El Madrid "Utópico" (1597-1600) de Cristóbal Perez de Herrera. In: Bulletin Hispanique. Vol 104, n. 104, Bordeaux, 2002, pp. 627-644.

CEBRIÀ, E.B. Felipe II: en sus dominios jamás se ponía el sol. Madrid: Anaya, c1988.

CERVERA VERA, L. Intervención de Juan de Herrera em Ediciones de Libros. Madrid: Instituto de Valencia de Don Juan, 1996.

CHASTEL, A. El gran taller de Italia. Trad. Arturo del Hoyo. Madrid: Aguillar, 1966.

O Artista. In: GARIN, E. (dir.). O Homem Renascentista. Lisboa: Editorial Estampa, 1991, pp.169-191, p.171.

CHARTIER, R. As práticas da escrita. In: ARIÈS, P.; DUBY, G. (dir). História da vida privada. Vol. 3: Da renascença ao Século das Luzes. Trad. Hildegard Feist. São Paulo: Cia das Letras, 2009, pp. 113-162.

CHAUNU, P. La España de Carlos V. Barcelona: Ediciones Peninsula, 1976.

CHECA CREMADES, F. Felipe II mecena de las artes. Madrid: Nerea, c. 1992.

CHUECA GOTIA, F. História de la Arquitectura Española. Ávila: Fundación Cultural Santa Teresa, Colégio Oficial de Arquitectura de Madrid, Universidade da Coriña, 2001. 
. Breve História do Urbanismo. Lisboa: Presença, 1992.

CONTRERAS, J. de. Historia del Arte Hispánico. Barcelona: Salvat Editores S.A., 1940.

CYMBALISTA, R. Relíquias sagradas e a construção do território cristão na Idade Moderna. In: Anais do Museu Paulista. Vol. 14. São Paulo: Universidade de São Paulo, 2006.

DALÍ, S. Libelo contra a arte moderna. Trad. Paulo Neves. Porto Alegre: L\&PM Pocket, 2008.

DENINA, C. Respuesta a la pregunta: ¿Qué se debe a España? Trad. Manuel de Urqullu. Cádiz: Imprenta de Manuel Ximénez Carreño, 1786.

D'AGOSTINO, M. H. Geometrias simbólicas da arquitetura. Espaço e ordem visual do Renascimento às Luzes. São Paulo: Editora Hucitec.

DÍAZ DÍAZ, T. "El entierro de San Lorenzo", posiblemente el mejor cuadro de Juan Fernández de Navarrete "el Mudo" (Padre Sigüenza). In:JAVIER CAMPOS, F. e SEVILLA, F. de (coord..). EI Monasterio del Escorial y la pintura: actas del Simposium, 1/5-IX-2001 / , 2001, ISBN 84-89942-24-2, págs. 561-580

DI TEODORO, F. P. Rafael, Baldessar Castiglione e la lettere a Leone $X$ sulle rovine di Roma. Bologna: Nuova Alfa, 1996.

EISLER, W. Charles $V$ and the Cathedral of Granada. in: The Journal of the Society of Architectural Historians, vol. 51, No. 2 (jun., 1992), pp. 174-181.

ELLIOTT, J. H. España, Europa y El mundo de ultramar (1500-1800). Trad. Marta Balcells y Juan Carlos Bayo. Madrid: Taurus, 2009.

Vives, 2005.

La España Imperial: 1469-1716. Trad. J. Marfany. Barcelona: Vicens

ELIAS, N. A sociedade de corte. Trad. Pedro Sussekind. Rio de Janeiro: ZAHAR, 2001.

O processo civilizador: uma história dos costumes. Trad. Ruy Jungmann. Rio de Janeiro: ZAHAR, 2001.

Mozart. Sociologia de um gênio. Trad. Sérgio Goes de Paula. Rio de Janeiro: Zahar, 1995.

ELORZA, A. Las ideas politicas. in: ARTOLA, M. (dir.). Enciclopedia de Historia de Espana. Vol. II. Iglesia. Pensamiento. Cultura. Madrid: Alianza Editorial, 1995, pp.129-153. 
ESTEBAN PIÑEIRO, M. Os oficios matemáticos en la España del siglo XVI. In: NAVARRO, Víctor; SALAVERT, Vicent L;. CORELL, M.; MORENO, E.; ROSSELLÓ, V. (coords.). Actes de les II Trobades d'Historia de la Ciencia i de la Tecnica: (Peníscola, 5-8 desembre 1992). Barcelona: Societat Catalana d'Història de la Ciència i de la Tècnica, 1993, pp.239-252.

Las Academias técnicas en la España del siglo XVI. In: Quaderns D'Història de l'enginyeria. Volum V. Barcelona: Universitat Politècnica da Catalunya, 2003, pp.10-18.

La ciencia en el siglo XVI español. In: HOURCADE, J. L. G.; YUSTE, J. M. M. Andrés Laguna. Humanismo, Ciencia y Política en la Europa Renacentista. Congresso Internacional (Segovia, 22-26 de noviembre de 1999). Madrid: Junta de Castilla y León; Consejería de Educación y Cultura, 2001, pp.22-40.

FEROS, A. Almas Gemelas: monarcas y favoritos en la primera mitad del siglo XVII. In: KAGAN, R.L.; PARKER, G. (eds.). España, Europa y el mundo Atlántico. Madrid: Marcial Pons; Junta de Castilla y León, 2001, pp.49-82.

FERNÁNDEZ ALBALADEJO, P. Fragmentos de Monarquía. Madrid: Alianza Universidad, 1992.

FERNÁNDEZ FERNÁNDEZ, C. La labor educadora de Cisneros y la primera biblioteca del renascimento de España. In: Anales de Documentación. Revista de Biblioteconomía y documentación. Vol. 5 Múrcia: Ediciones Universidad de Múrcia, 2002, pp. 81-97.

FIOLHAIS, C.; MARTINS, D. Breve História da Ciência em Portugal. Coimbra: Gradiva, 2010.

FORNER, J. P. Oración apologética por la España y su mérito literario, para que sirva de exornación al discurso leído por el abate Denina en la Academia de Ciencias de Berlín, respondiendo a la qüestion qué se debe a España?. Madrid: Imprenta Real, 1786.

GARCÍA DE COTÁZAR, F. e GONZÁLES VESGA, J. M. História de Espanha: uma breve História. Lisboa: Editorial Presença, 1997.

GARCÍA CÁRCEL, R. Felipe II y los historiadores del siglos XVII. in: BENNASSAR PERILLIER, B.; et. al. Vivir el Siglo de Oro. Poder, Cultura e História en la época moderna. Estudios en homenaje al profesor Ángel Rodríguez Sánchez. Salamanca: Universidad de Salamanca, 2003, pp.285-316.

GARCIA-FRÍAS, C.; SANCHO, J.L. Real monastério de San Lorenzo de EI Escorial. Madrid:.Reales Sítios de España, 2010.

GARCÍA MORALES, M. V. Los artistas que trabajan para el Rey: La Junta de Obras y Bosques. In: Espacio, Tiempo y Forma, Serie VI!, Historia del Arte, t. 3, 1990, págs. 123-136. 
GARCIA TAPIA, N. e RIVERA BLANCO, J. La presa de Ontígona y Felipe II. In: Revista de Obras Públicas, mayo-junio/1985, pp. 477-490.

GARCÍA TAPIAS, N. Descubrimientos e invención técnica. La actividad de los inventores españoles. In: CARABIAS TORRES, A. M. (coord.). Las relaciones entre Portugal y Castilla en la Época de los Descubrimientos. Salamanca: Ediciones Universidad de Salamanca, 1996, pp. 165-180.

GARIN, E. (dir.). O Homem Renascentista. Trad. Maria Jorge Vilar de Figueiredo. Lisboa: Presença, 1991.

. Ciência e vida civil no Renascimento italiano. Trad. Cecília Prada. São Paulo: Editora Unesp, 1996.

GARIN, E. O filósofo e o mago. In: idem (dir.). O Homem Renascentista. Trad. Maria Jorge Vilar de Figueiredo. Lisboa: Editorial Presença, 1991, pp. 121-144.

GAYA NUÑO, J. A. Los monumentos cardinales de España. Vol. VI: Madrid Monumental. Madrid: Editoria Plus-Ultra.

GINZBURG, C. O fio e os rastros. Verdadeiro, falso, fictício. São Paulo: Companhia das Letras, 2007.

2003.

Mitos, Emblemas, Sinais: Morfologia e História. São Paulo: Cia das Letras,

GOMEZ, M. E. La iconología. Un método para reconocer la simbología oculta en las obras de arquitectura. In: Argos, 38, julo 2003, pp. 7-39.

GONZÁLES ANTÓN, L. El territorio y su ordenación político-administrativa. In: ARTOLA, M. Enciclopedia de Historia de España. Vol. II: Instituições Políticas. Império. Madrid: Alianza, 1988, pp. 11-93.

GOODMAN, D. The Scientific revolution in Spain and Portugal. In.: PORTER, R.; TEICH, M. (ed.). The Scientific Revolution in Nacional Context. Great Britain: Cambridge University Press, 1992, pp.158-177.

. Philip II's Patronage of Science and Engineering. in: The British Journal for the History of Science, vol.16, N.1. Cambridge: Cambridge University Press, mar/1983, pp. 49-66.

GUILLAUME, J. (org.). Demeures D’Éternité. Eglises et chappelles funéraires aux XVe ET XVle siècles. Paris: Picard, 2005.

HESPANHA, A. M. Para uma teoria da história institucional do Antigo Regime. In: idem (org). Poder e instituições na Europa do Antigo Regime. Coletânea de textos. Lisboa: Fundação Calouste Gulbenkian, 1984, pp.07-89. 
HIGUERA, M. Á. , GÓMEZ MARTÍNEZ J., Herrera y su influencia: actas del simposio, Camargo, 14-17 julio 1992. Santander: Ed. Universidad de Cantabria, 1993.

JAGO, C. J. Tributos y cultura política en Castilla, 1590-1640. In: KAGAN, R.L.; PARKER, G. (eds.). España, Europa y el mundo Atlántico. Madrid: Marcial Pons; Junta de Castilla y León, 2001, pp.83-112.

JAVIER CAMPOS, F. y SEVILLA, F. de. Los reyes de España y la orden de San Jeronimo. Texto disponível na web em: http://www.javiercampos.com/files/Los\%20Reyes\%20de\%20Espana\%20y\%20La\%2 0Orden\%20de\%20San\%20Jeronimo.PDF, acesso em 20/janeiro/ 2011.

JIMÉNES DÍAZ, P. El coleccionismo manierista de los Austrias. Entre Felipe II y Rodolfo II. Espanha (sem cidade): Sociedad Estatal para la Commemoración de los Centenarios de Felipe II e Carlos V, c. 1997.

JUSTI, C. Velázquez y su Siglo. Trad. Karin Hellwig. Madrid: Ediciones Istmo, 1999.

KAGAN, R.L. Clío y la corona: escribir historia en la España de los Austrias. In: KAGAN, R.L.; PARKER, G. (eds.). España, Europa y el mundo Atlántico. Madrid: Marcial Pons; Junta de Castilla y León, 2001, 113-150.

KANTOROWICZ, E. H. Os dois corpos do rei. Um estudo sobre teologia política medieval. Trad. Cid Knipel Moreira. São Paulo: Companhia das Letras, 1998.

KOSELLECK, R. História, histórias e estruturas temporais formais. In: idem. Futuro Passado. Contribuição à semântica dos tempos históricos. São Paulo: Contraponto/PUC, 2006, pp.119-145, p.120.

KUBLER, M. S. G. Art and Arquitecture in Spain and Portugal and Their American Dominions (1500 to 1800). Bradford: Penguin Books, 1959.

LACARTA, M. Diccionario Del Siglo de Oro. Madrid: Alderabán, 1996.

LEFORT, C. A obra de pensamento e a história. In: idem. As formas da História. Ensaios de antropologia política. São Paulo: Ed. Brasiliense, 1979, pp.155-166.

LE GOFF, J. Antigo/Moderno. in: Enciclopédia Einaudi. Vol I. Memória-História. Torino: Giulio Einaudi, 1977.

LLEÓ CAÑAL, V. Los usos de la Antigüidad: colecciones arqueológicas en la España del Renacimiento. In: Reales Sítios, ano XL, n.156, 20 trimestre de 2003. Madrid: Patrimonio Nacional, pp.30-43.

LÓPEZ PINERO, J. M. ; NAVARRO BROTONS, V.; PORTELA MARCO, E. La actividad científica y tecnológica. In: ARTOLA, M. (dir). Enciclopedia de Historia de España. Vol. III: Iglesia. Pensamiento. Cultura. Madrid: Alianza, 1988, pp. 273-325. 
LÓPEZ PINERO, J. M. (dir.) Historia de la ciencia y la técnica en la corona de Castilla. Vol. III. Siglos XVI y XVII. Madrid: Junta de Castilla y León, Consejería de Educación y Cultura, 2002.

LORDA IÑARRA, J. Herrera y las grúas de la Basílica de El Escorial. In: Revistas de Obras Públicas. Madrid, n. 3367, agosto/junho 1997, p.81-104.

LOYN, H.R. Dicionário da Idade Média. Trad. Álvaro Cabral. Rio de Janeiro: Jorge Zahar Ed., 1997.

LOEWEN, A. B. Estilo desornamentado, arquitetura-chã: alguns aspectos do Renascimento na Península lbérica. In: Revista do Programa de Pós-Graduação em Arquitetura e Urbanismo/FAUUSP. São Paulo, vol.18, n. 30, dez. 2011, pp.5669.

MACIEL, J. Introdução. In: VITRUVIO. Tratado de Arquitetura. Trad. Justino Maciel. São Paulo: Martins Fontes, 2007.

MARAVALL, J. A. Cultura del Barroco: Analisis de una estrutura historica. Barcelona: Editorial Ariel, 1983.

. La oposición política bajo los Austrias. Barcelona: Ariel, 1974.

Estudios de historia del pensamiento español. Vol. II: La epoca del renacimiento. Madrid: Ediciones Cultura Hispánica, 1984.

MARÍAS, F. El siglo XVI. Gótico y Renacimiento. Madrid: Silex, 1992.

MARQUÉS LOZOYA, J. C. Historia del Arte Hispánico. Barcelona: Salvat Editores S.A, 1940.

MARTÍNEZ-BURGO GARCíA, P. El decoro. La invención de un concepto y su proyección artística. Revista de la Facultad de Geografía e Historia, núm. 2, 1988, págs. 91-102.

MATTOSO, J. Religião e Cultura na Idade Média Portuguesa. Lisboa: Circulo de Leitores, 2000.

MEGIANI, A. P. T. O Rei Ausente: festas e cultura política nas visitas dos Filipes a Portugal (1581 e 1619). São Paulo: Alameda, 2004.

- Memória e conhecimento do mundo: coleções de objetos, impressos e manuscritos nas livrarias de Portugal e Espanha. In: Anais do Museu Paulista. São Paulo, v.17. n.1, jan.- jun. 2009, p. 155-171.

MENENDEZ PELAYO, M. La ciencia española: polémicas, indicaciones y proyectos. Alicante: Biblioteva Virtual Miguel de Cervantes, 1999.Edição digital baseada na 2a edição de Madrid, Imprenta Central a cargo de Victor Saiz, 1879. 
Disponível na web em : http://www.cervantesvirtual.com/FichaObra.html?Ref=2032 Acesso em 20 de fevereiro de 2010.

MOREIRA, R. (dir.) História das fortificações portuguesas no mundo. Lisboa: Publicações Alfa, 1989.

MORVILLIERS, N. M. Espagne. In: Encyclopédie méthodique ou par ordre des matières. Géographie moderne. Vol. I. París: Pandoucke, 1782, p. 554-568.

NEBRIJA, A. Gramática de la lengua castellana. Barcelona: Lenkgua, 2007.

NIETO ALCAIDE, V. M.; MORALES, A. e CHECA, F. Arquitectura del renacimiento en España, 1488-1599. Madrid: Cátedra, 1993.

NIETO ALCAIDE, V. M. e CHECA CREMADES, F. El renacimiento: formación y crisis del modelo clásico. Madrid: Ediciones Istmo, 1993.

OLIVARI, M. Entre el trono y la opinión. La vida política castellana en los siglos XVI y XVII. Trad. Jésus Villanueva. Valladolid: Junta de Castilla y León, Consejeria de Cultura y Turismo, 2004.

ORNELAS BERRIEL, C. E. Cidades utópicas do renascimento. In: Revista Ciência e Cultura. vol.56, no.2, São Paulo apr./june 2004, pp.46-48.

PANOFSKY, E. Renascimento e Renascimentos na Arte Ocidental. Trad. Fernando Neves. Lisboa: Presença, 1981.

PARKER, G. Felipe II. Trad. Ricardo de la Huerta Ozores. Madrid: Alianza Editorial, 2004. Editorial, 1999.

La gran estrategia de Felipe II. Trad. José Luis Gil Arista. Madrid: Alianza . David o Goliath: Felipe II y su mundo en la década de 1580. In: KAGAN, R.L.; PARKER, G. (eds.). España, Europa y el mundo Atlántico. Madrid: Marcial Pons; Junta de Castilla y León, 2001, pp321-346.

PIMENTEL, J. The Iberian Vision: Science and Empire in the Framework of a Universal Monarchy, 1500-1800. in: Osiris, $2^{\text {nd }}$ Series, Vol. 15, Nature and Empire: Science and the colonial interprise. Chicago: The University of Chicago Press, 2000, pp.17-30.

POCOCK, J. G. A. Conceito e discursos: uma diferença cultural? Comentário sobre o paper de Melvin Richter. In: JASMIN, M. G.; FERES Jr., J. (orgs.). História dos conceitos: debates e perspectivas. Rio de Janeiro: Ediçoes Loyola, Editora PUC Rio; IUPERJ, 2006, pp. 83-96, p. 83-84. 
POLÓNIA, M. A. Arte, técnica e ciência náutica no Portugal Moderno. Contributos da 'sabedoria dos descobrimentos' para a ciência européia. In: Revista da Faculdade de Letras HISTÓRIA. Porto, III Série, vol. 6, 2005, pp.09-20.

PARDO TOMÁS, J. La difusión de la información científica y técnica. In: LOPES PIÑERO, J. A. (dir). História de la ciência y de la técnica en la corona de Castilla. Vol. III: Siglos XVI y XVII. Madrid: Junta de Castilla y León/ Consejería de Educación y Cultura, 2002.

RIO BARREDO, M. J. Madrid, Urbs Regia. La capital cerimonial de la monarquia católica. Madrid: Marcial Pons, 2000.

RODRíGUEZ, M. R. La España de Don Quijote: Un viaje al Siglo de Oro. Alianza Editorial

RODRÍGUEZ MOLINA, J. El monastério de San Jeronimo de Granada. Patrimonio y "más allá". In: Gazeta de Antropogía, n. 25, 2009. Disponível na web em: http://www.ugr.es/ pwlac/G25_15Jose_Rodriguez_Molina.html Acesso em 22/jan./2010.

RODRÍGUEZ LUNA, D. Algunos aspectos de la caridad en la orden de San Jeronimo. In: JAVIER CAMPOS, F. e SEVILLA, F. de (coord..). La Iglesia española y las instituciones de caridad. Escorial: Ediciones Escurialenses; Real Centro Universitario Escorial-María Cristina, 2006, págs. 923-950.

RODRÍGUEZ LUNA, D. Ermitas dedicadas a San Jerónimo en España: ayer y hoy de una devoción en el corazón de la Iglesia. In: El culto a los santos: cofradías, devoción, fiestas y arte. Escorial: Ediciones Escurialenses; Real Centro Universitário Escorial-María Cristina, 2008, págs. 935-950.

RODRIGUEZ TORO, Descripción y cosmografía de España (o itinerário) de Hernando Colón: sus "aportaciones" a los historiadores. In: Historia, instituciones, documentos. Sevilha: Departamento de Historia Medieval y Ciencias y Técnicas Historiográficas da Universidade de Sevilha, nํ27, 2000, págs. 275-294.

ROSSI, P. A ciência e a filosofia dos modernos. Trad. Ávaro Lorencini. São Paulo: Editora Unesp, 1992.

A chave universal. Artes da memorização e lógica combinatória desde Lúlio até Leibniz. Trad. Antonio Angonese. Bauru: Edusc, 2004.

O passado, a memória, o esquecimento. Seis ensaios da história das ideias. Trad. Nilson Moulin. São Paulo: Editora Unesp, 2007.

. Os filósofos e as máquinas. Trad. Frederico Carotti. São Paulo: Cia das Letras, 1989 (1ํㅡㄹ edição italiana 1962).

O nascimento da ciência moderna na Europa. Trad. Antonio Angonese. Bauru: EDUSC, 1997. 
. Francis Bacon. Da magia à ciência. Trad. Aurora Fornoni Bernardini. Londrina: Eduel, 2006.

SÁNCHEZ RON, J. M. La ciencia en el Monasterio del Esocrial. In: JAVIER CAMPOS, F. e SEVILLA, F. de. Actas Del Simposium. Vol. 1. Escorial: Real Centro Universitario Escorial-María Cristina Pp.39-72.

SANCHIS MORENO, F. J. Honorato Juan: vida y recuerdo de um maestro de príncipes. Valência: Biblioteca Valenciana, 2002.

SANTILLANA, G. de. O papel da arte no renascimento científico. São Paulo: FAUUSP, 1981.

SANTOS, C. D. Os monges Jerônimos em Portugal na Época dos Descobrimentos. Lisboa: Instituto de Cultura e Língua Portuguesa, 1ª Ed., 1984.

SERRÃO, J. Dicionário de História de Portugal. Porto: Figueirinhas, 1981, Vol. VI.

SCHIERA, P. Sociedade "de estados" "de ordens" ou corporativa. In.: HESPANHA, A. M. (org). Poder e instituições na Europa do Antigo Regime. Coletânea de textos. Lisboa: Fundação Calouste Gulbenkian, 1984, pp.143-153.

SKINNER, Q. As fundações do pensamento político moderno. Trad. Renato Janine Ribeiro e Laura Teixeira Motta. São Paulo: Cia das Letras, 1996.

SOUSA, L. C. A arte na guerra. A arquitetura dos campos de batalha no Portugal de quinhentos. Lisboa: Tribuna da Historia, 2008.

SOUSA, M. L. Z. Carta de Rafael Sanzio - Catilione ao Papa Leão X e sua importância para o estudo da arquitetura e urbanismo do período do Renascimento (Dissertação de mestrado). São Paulo: Faculdade de Arquitetura e Urbanismo da Universidade de São Paulo, 2006.

STRONG, R. Arte y Poder. Fiestas del Renacimiento (1450-1650). Trad. Maribel de Juan. Madrid: Alianza Editorial, 1988.

TAFFURI, M. Ricerca del Rinacimento. Principi, città, architetti. Torino: Einaudi, 1993.

TAYLOR, R. Arquitectura y magia. Colaboraciones sobre la Idea de El Escorial. Trad. José Luis Oliver Domingo. Madrid: Siruela, $3^{\underline{a}}$ ed., 2000.

TAVARES, D. Juan de Herrera: disciplina na arquitectura. Porto: Editora Dafne, 2005.

TEIXEIRA, F. G. História da Matemática em Portugal. Coimbra: Imprensa da Universidade, 1934. 
UNAMUNO, M. El caballero de triste figura.(1896) In: idem. Ensaios. Madrid: Aguiar, 1958.

URBANO, C.M. Heroísmo, santidade e martírio no tempo das reformas. In:

Península. Revista de Estudos Ibéricos, n.1, 2004, pp. 269-276.

VASARI, G (1550/1568). Vidas dos Artistas. Trad. Ivone Castilho Benedetti. São Paulo: Martins Fontes, 2011, $1^{\mathrm{a}}$ ed.

VILLALPANDO, F. Sebastiano Serlio, tercero y quarto libro de architectura. Madrid, 1552. Edição Facssimile. Valencia: Albatro Ed, 1997.

VILAR, P. História de España. Lisboa: Livros Horizonte, 1992.

VILLARI, R. (dir.). O Homem Barroco. Lisboa: Presença, 1995.

VICENS VIVES, J. e ORTEGA, R. Historia Social y Economica de España y America. Barcelona: Editorial Vicens Vives, 1977, 5v.

VICENS VIVES, J. A estrutura administrativa estadual nos séculos XVI e XVII. in: HESPANHA, A. M. (org). Poder e instituições na Europa do Antigo Regime. Coletânea de textos. Lisboa: Fundação Calouste Gulbenkian, 1984, pp.201-229.

VICENTE MAROTO, M. I. Juan de Herrera y la ingenieria. In: ARAMBURU-ZABALA, M. A.(dir.) e GÓMEZ MARTÍNEZ, J. Juan de Herrera e su influencia. Actas del simpósio. Camargo, 14/17 julio 1992. Santander: Unversidad de Cantábria/Fundación Obra Pía de Juan de Herrera, 1993, pp.79-89, p.81

VITRUVIO. Tratado de Arquitetura. Trad. M. Justino Maciel. São Paulo: Martins Fontes, 2007.

WAGNER, K. La biblioteca colombina en tiempos de Hernando Colón. In: Historia, instituciones, documentos. Sevilha: Departamento de Historia Medieval y Ciencias y Técnicas Historiográficas da Universidade de Sevilha, № 19, 1992, págs. 485-495

WARNKE, M. O artista da corte: Os antecedentes dos artistas modernos. Trad. Maria Clara Cestato. São Paulo: Edusp, 2001.

WILKINSON-ZERNER, C. Juan de Herrera: Arquitecto de Felipe II. Trad. Isabel Balsinde. Madrid: Ediciones Akal, 1996.

Planning a Style for the Escorial: An architectural treatise for Philip of Spain. in: The Journal of the Society of Architectural Historians, vol. 44, No. 1 (mar. 1985), pp. 37-47.

YATES, F. A arte da memória. Trad. Flavia Bancher. Campinas: Editora Unicamp, 2007. 
YUN CASALILLA, F. Mal aveninos, pero juntos. Corona y oligarquias urbanas en Castilla en el siglo XVI. In: BENNASSAR PERILLIER, B.; et. al. Vivir el Siglo de Oro. Poder, Cultura e História en la época moderna. Estudios en homenaje al profesor Ángel Rodríguez Sánchez. Salamanca: Universidad de Salamanca, 2003, pp. 62-76.

VAS MINGO, M. M. Las Ordenanzas de 1573, sus antecedentes y consecuencias. In: Revista Quinto Centenario. Madrid: Universidad Complutense de Madrid, 1985, Número 8, pp. 83-101. 